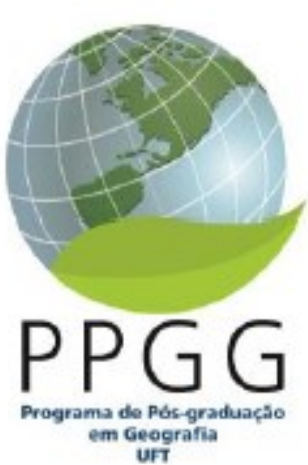

UNIVERSIDADE FEDERAL DO TOCANTINS

PROGRAMA DE PÓS-GRADUAÇÃO EM GEOGRAFIA

CAMPUS DE PORTO NACIONAL

MILLENA ADRIANNA FORMIGA DIAS BERNARDELI

BACIA DO CÓRREGO SÃO JOÃO \& SEGURANÇA HÍDRICA DO ABASTECIMENTO URBANO DO MUNICÍPIO DE PORTO NACIONAL-TO 
MILLENA ADRIANNA FORMIGA DIAS BERNARDELI

BACIA DO CÓRREGO SÃO JOÃO \& SEGURANÇA HÍDRICA DO ABASTECIMENTO URBANO DO MUNICÍPIO DE PORTO NACIONAL-TO

Dissertação de Mestrado apresentada ao Programa de Pós-Graduação Stricto Sensu em Geografia, da Universidade Federal do Tocantins, para obtenção do título de Mestre em Geografia.

Orientador: Prof. Dr. Lucas Barbosa e Souza

Co-orientadora: Prof. Dra. Rosa Maria Formiga Johnsson 
Dados Internacionais de Catalogação na Publicação (CIP) Sistema de Bibliotecas da Universidade Federal do Tocantins

B522b Bernardeli, Millenna Adrianna Formiga Dias.

Bacia do córrego Säo Joäo \& Segurança hídrica do abastecimento urbano do município de Porto Nacional/TO. / Millenna Adrianna Formiga Dias Bernardeli. - Porto Nacional, TO, 2017.

$142 \mathrm{f}$

Dissertaçäo (Mestrado Acadêmico) - Universidade Federal do Tocantins - Câmpus Universitário de Porto Nacional - Curso de PósGraduaçäo (Mestrado) em Geografia, 2017.

Orientador: Lucas Barbosa e Souza

Coorientadora : Rosa Maria Formiga-Johnsson

1. Segurança hídrica. 2. Abastecimento urbano. 3. Disponibilidade qualiquantitativa. 4. Córrego Sảo João, Porto Nacional-TO. I. Título

CDD 910

TODOS OS DIREITOS RESERVADOS - A reprodução total ou parcial, de qualquer forma ou por qualguer meio deste documento é autorizado desde que citada a fonte. A violacão dos direitos do autor (Lei no 9.610/98) é crime estabelecido pelo artigo 184 do Código Penal.

Elaborado pelo sistema de geração automatica de ficha catalográfica da UFT com os dados fornecidos pelo(a) autor(a). 


\section{BACIA DO CÓRREGO SÃO JOÃO E SEGURANÇA HÍDRICA DO ABASTECIMENTO PÚBLICO DO MUNICÍPIO DE PORTO NACIONAL - TO}

Dissertação apresentada ao Programa de Pós-Graduação em Geografia da Universidade Federal do Tocantins (UFT), Câmpus de Porto Nacional, como requisito para obtenção do título de Mestre em Geografia.

Aprovada em: 10 de julho de 2017.

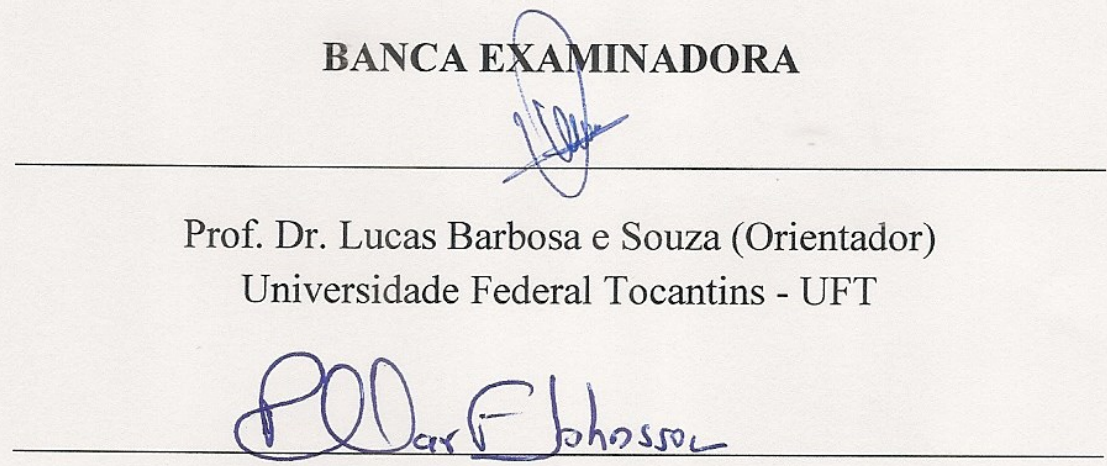

Profa. Dra. Rosa Maria Formiga Johnsson (Co-Orientadora)

Universidade do Estado do Rio de Janeiro - UERJ

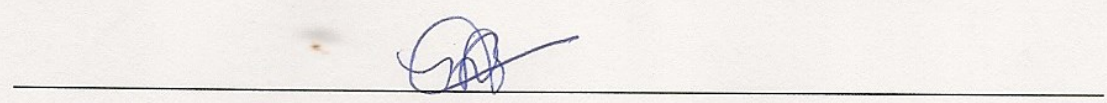

Profa. Dra. Marciléia Oliveira Bispo

Universidade Federal Tocantins - UFT

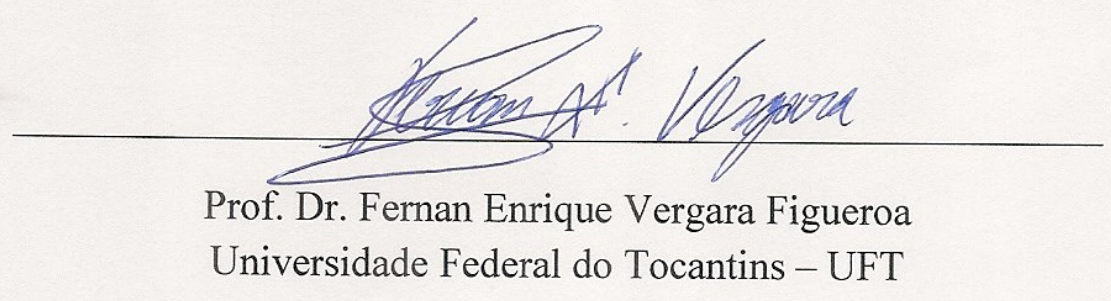

Porto Nacional - TO

2017 
Aos meus pais José Marcelos e Maria de Jesus (Dushy) (in memoriam) e à minha querida e cheirosa vovó Rosa (in memoriam) pelos princípios e exemplos de vida que sempre me incentivaram na concretização de meus ideais. Dedico também à minha família e aos portuenses. 


\section{AGRADECIMENTOS}

À DEUS, pela vida, benção e proteção.

À Universidade Federal do Tocantins - UFT, como instituição de ensino público e de qualidade, seus professores e técnicos, pela oportunidade, apoio e auxílio.

Ao IFTO - Instituto Federal de Educação, Ciência e Tecnologia do Tocantins - Campus Porto Nacional, pela concessão da licença para capacitação.

Ao Prof. Dr. Lucas Barbosa e Souza, meu orientador, por todo o direcionamento e orientação para a conclusão desta dissertação.

À Prof. Dra. Rosa Maria Formiga Johnsson, minha co-orientadora, você é o meu melhor exemplo seja na vida pessoal e/ou profissional. Obrigada pelos seus ensinamentos, sua assertividade e sabedoria e por construir meu alicerce e edificar com maestria o desenvolvimento desse estudo.

Aos professores da banca de qualificação, doutor Fernan Vergara e doutora Marcileia Bispo, pelas suas valiosas contribuições e sugestões de aprimoramento desta dissertação.

A todos os professores do Departamento de Geografia e do Departamento de Biologia pelo diálogo e indicações em toda essa trajetória.

À minhas tias-mães Terezinha, Gracinha e Rosinha que sempre acreditaram em mim e nunca mediram esforços para viver e dividir os momentos mais importantes da minha vida. Obrigada por todo esse amor que é recíproco.

À minha irmã Marcella, pela paciência eterna e apoio emocional incondicional, te amo maninha.

Ao meu esposo, Marcello, que durante essa jornada me incentivou o tempo todo com o seu jeito ímpar, cookie, divertido e simples de ser, amo demais você.

Às minhas famílias Formiga, Dias e Bernardeli, que me deram amor e força, valorizando meu potencial, demonstrando sempre compreensão e carinho.

Agradeço a todos os amigos da vida e do ofício que, mesmo não citados nominalmente, sabem da minha gratidão e consideração pela torcida sincera para a finalização deste trabalho. 


\section{RESUMO}

BERNARDELI, M.A.F.D. Bacia do Córrego São João \& Segurança Hídrica do abastecimento urbano do município de Porto Nacional/ TO. 2017. 138p. Dissertação de Mestrado - Campus Porto Nacional, Universidade Federal do Tocantins, Porto Nacional.

Esta dissertação teve como objetivo principal avaliar o nível de segurança hídrica do abastecimento público de Porto Nacional/TO, associado à quantidade e qualidade de água bruta da bacia do Córrego São João, seu único manancial de abastecimento. Adotou-se o modelo conceitual e metodológico desenvolvido pelo Grupo de Pesquisa "Água, Gestão e Segurança Hídrica em tempos de Mudanças Ambientais Globais", do qual a autora é parte integrante. O modelo baseia-se no conceito de segurança hídrica associado, de um lado, a riscos qualiquantitativos da água bruta no ponto de captação e, de outro lado, na sua compatibilidade com o sistema de abastecimento público, em particular os subsistemas de captação e tratamento. Dessa forma, foi possível avaliar, de forma qualitativa, a segurança hídrica do abastecimento de Porto Nacional-TO/Bacia do Córrego São João, perante quatro fatores de estresse: i) pressão sobre as condições ambientais; ii) demanda por água; iii) carga poluidora; e iv) eventos hidrológicos extremos (seca e inundação). Os resultados apontam que o maior estressor de risco à segurança hídrica do abastecimento de Porto Nacional se relaciona à demanda por água, pois a disponibilidade hídrica se encontra no seu limite e o uso da água a montante da captação da ETA continua a crescer. Por outro lado, constatou-se que as condições ambientais da Bacia têm sido progressivamente pressionadas, sobretudo pela agricultura e pastagens, além da notória expansão urbana. A qualidade de água e as secas/estiagens agravam esse quadro. Por fim, o principal resultado aponta para uma aparente compatibilidade entre a disponibilidade qualiquantitativa da água bruta do Córrego São João e os subsistemas de captação e tratamento da ETA 02, atualmente. Contudo, avaliou-se também que a Bacia se encontra próxima ao limite crítico, enquanto manancial de abastecimento de Porto Nacional.

Palavras-Chaves: Segurança hídrica, abastecimento urbano, disponibilidade qualiquantitativa, Córrego São João, Porto Nacional-TO. 


\begin{abstract}
BERNARDELI, M.A.F.D. São João Stream Basin and Water Security of the Urban Supply of the Municipality of Porto Nacional / TO. 2017. 138p. Master's Dissertation - Porto Nacional Campus, Federal University of Tocantins, Porto Nacional.

The São João stream is the strategic source for supplying the municipal headquarters of Porto Nacional. This dissertation aimed to identify the main risks and vulnerabilities to the public supply of Porto Nacional / TO, associated to the quantity and quality of raw water of the Córrego São João basin, and to analyze the level of current and future water security of the municipality. We adopted the model developed by members of the Research Group "Water, Water Management and Safety in times of Global Environmental Change".Thus, it was possible to develop a methodology of analysis of water security of urban supplies, specific to the São João Stream basin in Porto Nacional / TO, considering four stress factors considered as the most determinant for current vulnerability: i) pressure On environmental conditions; li) demand for water; (lii) pollutant load and (iv) extreme hydrological events. The results showed that the greatest stressor to the water security of the supply of Porto Nacional, related to the problems of quantity and quality of raw water, is the demand for water. On the other hand, the pressure on the environmental conditions of the Basin was evidenced by the preparation and analysis of maps of land use and occupation in 2006, 2011 and 2016; The evolution (in time and space) of the anthropic occupation with implantation of temporary crops and of pastures, besides the notorious urban expansion, was verified. We did not identify any records of total paralysis of ETA 02. The main result shows that, currently, there is still compatibility between the quali-quantitative availability of the raw water of the São João Stream and the subsystems of capture and treatment of ETA 02.
\end{abstract}

Keywords: Water security, urban supply, qualiquantitative availability, Córrego São João, Porto Nacional-TO. 


\section{LISTA DE TABELAS}

TABELA 1 - Produto interno bruto - município de porto nacional, $2010 \ldots \ldots \ldots . . .56$

TABELA 2 - Comparação do uso e ocupação da terra 2006, 2011 e 2016 ....... 82

TABELA 3 - Uso e ocupação das apps da bacia ano de 2006 e 2016 ............. 91

TABELA 4 - Pressão sobre as condições ambientais - 2016 ........................ 95

TABELA 5 - Empreendimentos rurais a montante do ponto de captação ........ 114

TABELA 6 - Localização dos pontos de coleta de água no córrego São João em Porto Nacional ...................................................... 116

TABELA 7 - Análise de desconformidades dos parâmetros de qualidade de água bruta nos limites das Classes 2 e 3 da Resolução Conama $N^{\circ}$

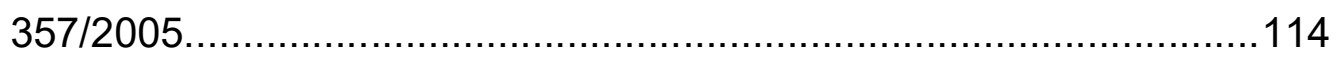




\section{LISTA DE QUADROS}

QUADRO 1 - Graduação qualitativa dos estressores, por propriedade 43

QUADRO 2 - Estressores de água bruta selecionados para compor o modelo analítico de avaliação da segurança hídrica do abastecimento urbano. 47

QUADRO 3 - Densidade demográfica Município de Porto Nacional 56

QUADRO 4 - Parâmetros morfométricos para definição do padrão, da forma e das características do relevo na bacia do córrego São João. 59

QUADRO 5 - Levantamento dos Estudos Realizados sobre a Bacia do Córrego São João. 66

QUADRO 6 - Vazões demandadas estimadas para Abastecimento Humano por Sub-bacias. 72

QUADRO 7 - Reservatórios existentes na sede de Porto Nacional 77

QUADRO 8 - Comparativo de Ligações Ativas de Água 77

QUADRO 9 - Dados das vazões mensais em $\mathrm{m} 3 / \mathrm{s}$ 99

QUADRO 10 - Disponibilidade hídrica média (m3/s) na foz do Córrego São João99 QUADRO 11 - Quantitativo e vazão outorgada por finalidade de uso no Córrego São João 102

QUADRO 12 - Demandas hídricas e evolução da demanda (abastecimento público, dessedentação de animais e agricultura irrigada) na bacia hidrográfica do Córrego São João 104

QUADRO 13 - Demanda de água de Porto Nacional - Sede 106

QUADRO 14 - Consumo percapita e perdas da sede municipal de Porto Nacional, em 2012 e estimadas até 2042 ............................. 106

QUADRO 15 - Demanda de água de Porto Nacional - Sede 107

QUADRO 16 - Balanço hídrico entre disponibilidades e demandas outorgadas e estimadas, e comprometimento (\%) da disponibilidade hídrica média e de referência na bacia. 108

QUADRO 17 - Balanço hídrico atual e projetado entre as disponibilidades e as demandas hídricas 109 


\section{LISTA DE FIGURAS}

FIGURA 1 - Mapa de localização da Bacia Hidrográfica do Córrego São João em Porto Nacional-TO.

FIGURA 2 - Modelo analítico para avaliação qualitativa de segurança hídrica de sistemas de abastecimento urbano 35

FIGURA 3 - Matriz de determinação do grau de risco, por estressor 44

FIGURA 4 - Modelo analítico de segurança hídrica: Vulnerabilidade do sistema de abastecimento urbano de água. 51

FIGURA 5 - Matriz de determinação da vulnerabilidade 52

FIGURA 6 - Áreas estratégicas de gestão e localização da Bacia Hidrográfica do Lago de Palmas, no estado do Tocantins. 54

FIGURA 7 - Mapa de localização da Bacia Hidrográfica do Córrego São João em Porto Nacional-TO 55

FIGURA 8 - Localização do ponto de captação da sede municipal de Porto Nacional. 57

FIGURA 9 - Mapa de Hipsometria da bacia do córrego São João 60

FIGURA 10 - Perfil Topográfico do Córrego São João. 60

FIGURA 11 - Mapa de Declividade da Bacia do Córrego São João 61

FIGURA 12 - Mapa de temático de uso e ocupação da terra na bacia hidrográfica do Córrego São João, no período de 1980 a 2012 . .... 64

FIGURA 13 - Barragem no Córrego São João ...................................... 71

FIGURA 14 - Ponto de captação superficial na represa - Fazenda Jaiara ......... 72

FIGURA 15 - Estação de Tratamento de Água de Porto Nacional - ETA 02 ..... 73

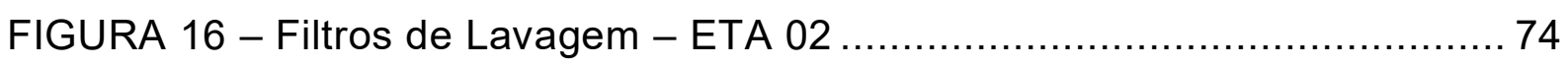

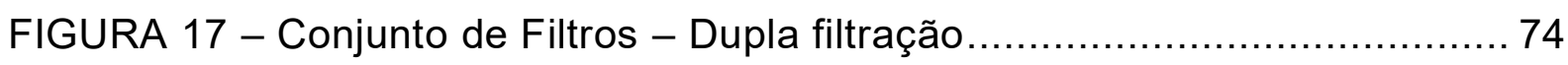

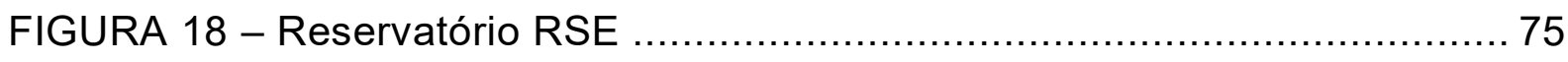

FIGURA 19 - Reservatório REL localizado na ETA $02 \ldots \ldots \ldots \ldots \ldots \ldots \ldots \ldots \ldots \ldots$

FIGURA 20 - Reservatório REL localizado no escritório da cia de abastecimento76

FIGURA 21 - Reservatório RAP e REL Ipês ...................................... 76

FIGURA 22 - Chave de interpretação utilizada no processo de classificação de

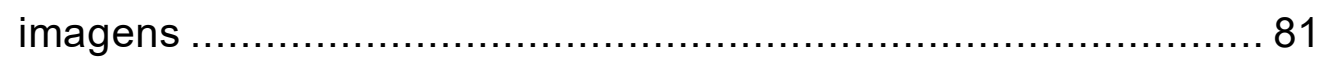

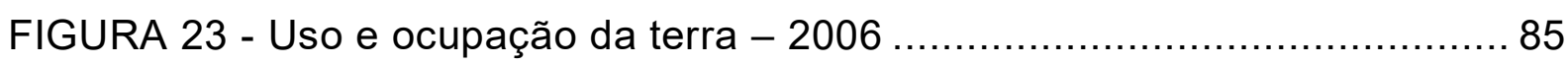

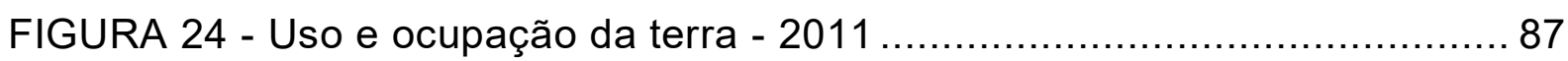


FIGURA 25 - Corrente usada em ação de desmatamento na bacia outubro de 2015

FIGURA 26 - Presença de maquinário para desmatamento na bacia outubro de 2015 88

FIGURA 27 - Área recém desmatada na bacia outubro de 2015 89

FIGURA 28 - Uso e ocupação da terra - 2016. 90

FIGURA 29 - Situação das APPs Fluviais na área de contribuição do Córrego São João 2006 93

FIGURA 30 - Situação das APPs Fluviais na área de contribuição do Córrego São João 2016

FIGURA 31 - Matriz de risco associado à pressão sobre as condições ambientais da Bacia.

FIGURA 32 - Outorgas e Declaração de Usos Insignificantes do direito de uso da água autorizados pelo Naturatins na bacia do Córrego São João101

FIGURA 33 - Síntese da Bacia do Córrego São João. 104

FIGURA 34 - População censitária de Porto Nacional (Sede) - Censos IBGE 105 FIGURA 35 - Projeção populacional - Porto Nacional - TO - 2013/2042 ....... 105 FIGURA 36 - Matriz de risco associado à demanda por água (pressão sobre a quantidade)

FIGURA 37 - Fazendas com plantações de Soja na margem esquerda da Bacia do Córrego São João 115

FIGURA 38 - Fazendas com plantações de Soja na margem direita da Bacia do Córrego São João . 115

FIGURA 39 - Classificação da qualidade da água 117

FIGURA 40 - Matriz de risco associado à demanda por água (pressão sobre a quantidade) 121

FIGURA 41 - Climograma da município de Porto Nacional (2015) 123

FIGURA 42 - Represa de Abastecimento 124

FIGURA 43- Represa de Abastecimento 124

FIGURA 44 - Represa de Abastecimento 125

FIGURA 45 - Represa de Abastecimento 125

FIGURA 46 - Matriz de risco associado à eventos hidrológicos extremos (pressão sobre a quantidade) 
FIGURA 47 - Vulnerabilidade do Sistema de Abastecimento/Subsistema de captação de Porto Nacional em diferentes situações

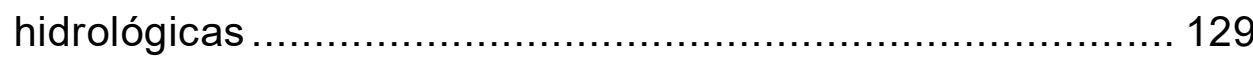

FIGURA 48 - Vulnerabilidade do Sistema de Abastecimento de Porto Nacional/Subsistema de tratamento em diferentes situações hidrológicas 131

FIGURA 49 - Matriz dos riscos associados aos estressores analisados 132 


\section{LISTA DE ABREVIATURAS E SIGLAS}

$\begin{array}{ll}\text { AEG } & \text { Área Estratégica de Gestão } \\ \text { ANA } & \text { Agência Nacional das Águas } \\ \text { APPs } & \text { Áreas de Preservação Permanente } \\ \text { CONAMA } & \text { Conselho Nacional do Meio Ambiente } \\ \text { CNRH } & \text { Conselho Nacional de Recursos Hídricos } \\ \text { ETA } & \text { Estação de Tratamento de Água } \\ \text { ETE } & \text { Estação de Tratamento de Esgoto } \\ \text { IBGE } & \text { Instituto Brasileiro de Geografia e Estatística } \\ \text { IPCC } & \text { Painel Intergovernamental sobre Mudanças Climáticas } \\ \text { IQA } & \text { Índice de Qualidade das Águas } \\ \text { ITERTINS } & \text { Instituto de Terras do Tocantins } \\ \text { KM } & \text { Quilômetros } \\ \text { M } & \text { Metros } \\ \text { MPE-TO } & \text { Ministério Público do Estado do Tocantins } \\ \text { NASA } & \text { National Aeronautics and Space Administration } \\ \text { NATURATINS } & \text { Instituto Natureza do Tocantins } \\ \text { PMAE } & \text { Plano Municipal de Água e Esgoto } \\ \text { OCDE } & \text { Organização para Cooperação e Desenvolvimento Econômico } \\ \text { ONU } & \text { Organização das Nações Unidas } \\ \text { SEGRH } & \text { Sistema Estadual de Gestão dos Recursos Hídricos } \\ \text { SEPLAN-TO } & \text { Secretaria do Planejamento e Meio Ambiente do Tocantins } \\ \text { SIG } & \text { Sistema de Informações Geográficas } \\ \text { SNIS } & \text { Sistema Nacional de Informação de Saneamento } \\ \text { SPRING } & \text { Sistema de Processamento de Informações Geográficas } \\ \text { TIFF } & \text { Tagged Image File Format } \\ \text { UERJ } & \text { Universidade Estadual do Rio de Janeiro } \\ \text { UFT } & \text { Universidade Federal do Tocantins } \\ \text { UHE } & \text { Usina Hidrelétrica Luís Eduardo Magalhães } \\ & \end{array}$


1 INTRODUÇÃO

1.1 Objetos de estudo: bacia do Córrego São João e a ETA 02 ………….....18

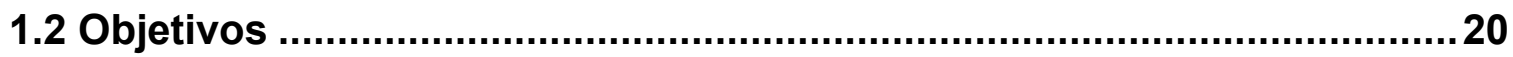

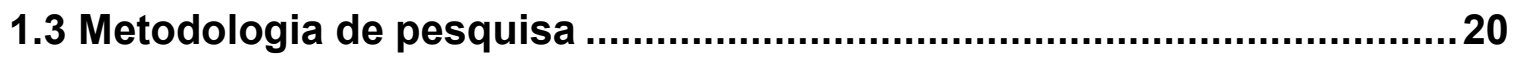

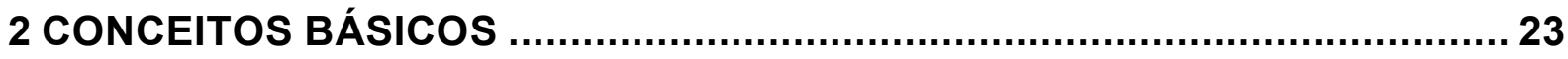

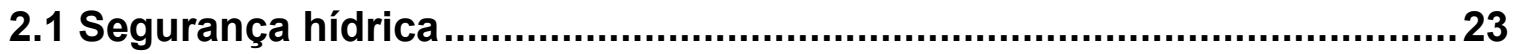

3 MODELO CONCEITUAL E METOdOLÓgICO PARA AVALIAÇÃo QUALITATIVA DA SEGURANÇA HÍDRICA NO ABASTECIMENTO

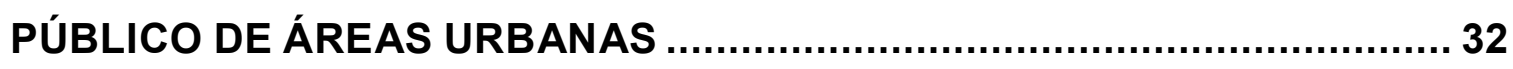

3.1 Delimitação do modelo...................................................................... 32

3.2 Modelo para avaliação qualitativa da segurança hídrica de

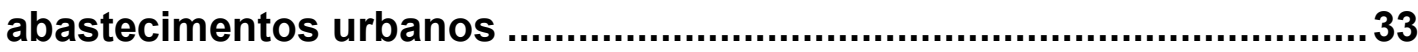

3.3 Definição de estressores, impactos e ações de gestão na bacia

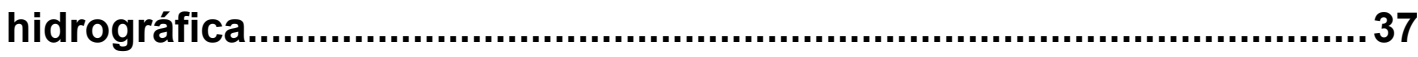

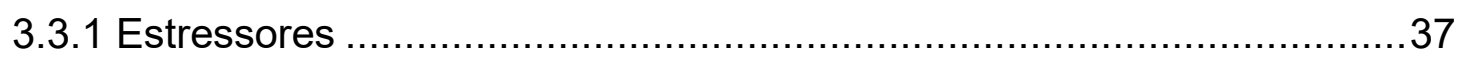

3.3.1.1 Pressão sobre as condições ambientais da bacia hidrográfica ..38

3.3.1.2 Demanda por água (pressão sobre a quantidade) .....................38

3.3.1.3 Carga poluidora (pressão sobre a qualidade da água) ..............39

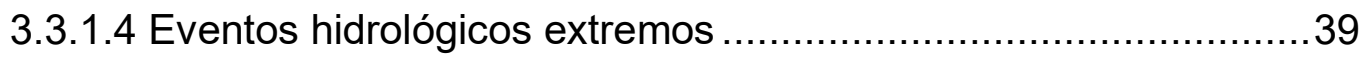

3.3.1.5 Acidentes ambientais .......................................................... 40

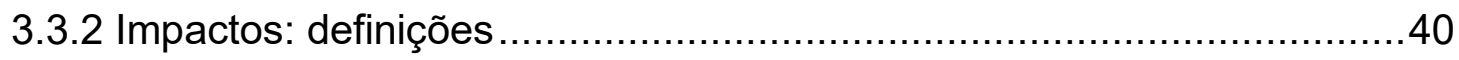

3.4 Avaliação qualitativa do risco associado à segurança hídrica do

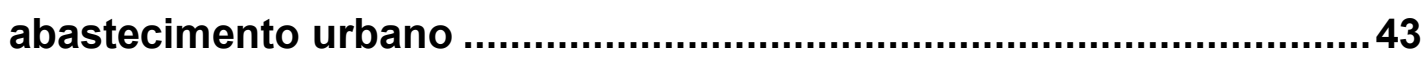

3.4.1 Avaliação qualitativa de risco associada a cada estressor ..................43

3.4.2 Severidade do impacto de estressores ..............................................4

3.4.2.1 Severidade do impacto sobre a quantidade .............................45

3.4.2.2 Severidade do impacto sobre a qualidade ..............................46

3.4.2.3 Resumo dos indicadores relativos ao impacto dos estressores

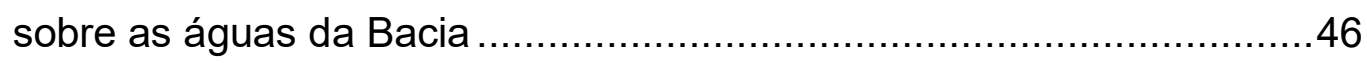

3.5 Vulnerabilidade do sistema de abastecimento urbano perante sua exposição ao risco associado à água bruta ...........................................47

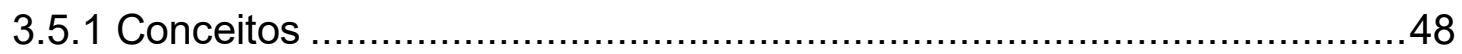


3.5.2 Metodologia de avaliação da vulnerabilidade 49

4 CARACTERIZAÇÃO DO OBJETO DE ESTUDO 53

4.1 Bacia hidrográfica do Córrego São João 53

4.1.1 Características ambientais da Bacia do Córrego São João .58

4.1.2 Uso e ocupação da terra da bacia no período de 1980 a 2016 .62

4.1.3 Outros estudos realizados na Bacia do Córrego São João 65

4.2 Sistema de abastecimento urbano de Porto Nacional .70

4.2.1 Captação e tratamento .71

4.2.2 Estação de tratamento de água .73

4.2.3 Reservação de água .75

5 APLICAÇÃO DO MODELO ANALítICO DE SEGURANÇA HÍDRICA NO SISTEMA DE ABASTECIMENTO DE PORTO NACIONAL-TO: RESULTADOS E DISCUSSÕES 78

5.1 Segurança hídrica associada à água bruta...........................................78

5.1.1 Estressor da água bruta (1): pressão sobre as condições ambientais ..79

5.1.1.1 Uso e ocupação da terra e cobertura vegetal na bacia ...............79

5.1.1.2 Área de Preservação Permanente - APP Fluvial ......................91

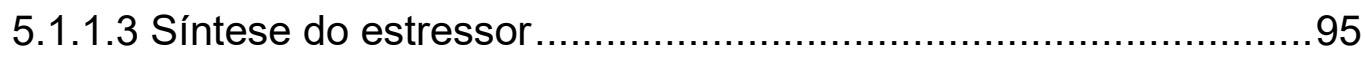

5.1.1.4 Ações de gestão em execução com interferência no uso e

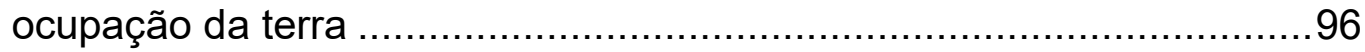

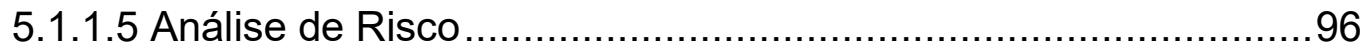

5.1.2 Estressor de água bruta (2): Demanda por água (pressão sobre a

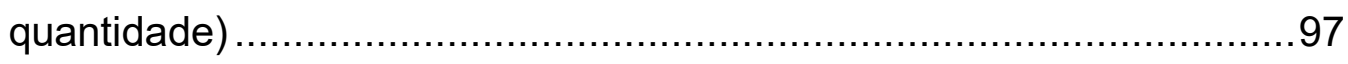

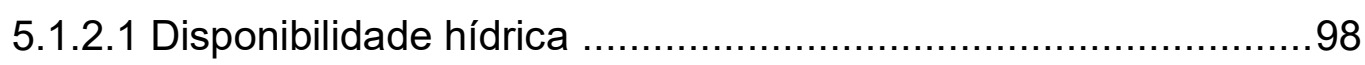

5.1.2.2 Demanda: Usos e usuários de água .....................................100

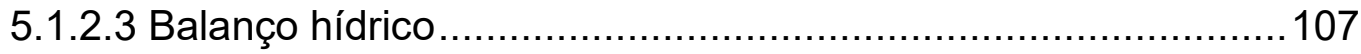

5.1.2.4 Ações de gestão em execução com interferência na demanda

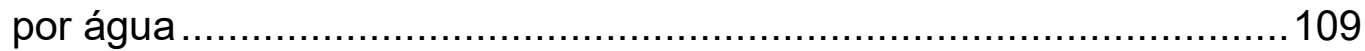

5.1.2.5 Análise do risco 111

5.1.3 Estressor da água bruta (3): carga poluidora (pressão sobre a qualidade das águas)

5.1.3.1 Fontes pontuais e difusas de poluição. 113

5.1.3.2 Avaliação da qualidade da água do Córrego São João 116

5.1.3.3 Ações de gestão para o controle da poluição das águas 119 
5.1.3.4 Análise do Risco 120

5.1.4 Estressores de água bruta (4): eventos hidrológicos extremos 122

5.1.4.1 Precipitação no município de Porto Nacional 122

5.1.4.2 Ocorrência de Seca/estiagem severa ............................. 124

5.1.4.3 Inundação 125

5.1.4.4 Ações de gestão em execução para mitigação dos efeitos de eventos hidrológicos extremos 125

5.1.4.5 Análise do risco 126

5.1.5 Estressor de água bruta (5): acidentes ambientais (fontes fixas e móveis)

5.2 Sistema de Abastecimento Público - ETA 02: avaliação qualitativa da vulnerabilidade 128

5.2.1 Subsistema de captação 128

5.2.2 Subsistema de tratamento. 130

5.3 Síntese dos resultados e discussões 131 6 CONCLUSÃO 135 


\section{INTRODUÇÃO}

A água é um elemento vital para a humanidade e para os ecossistemas por ser indispensável para a manutenção da vida e para o desenvolvimento das atividades agrícolas e industriais. $\mathrm{O}$ termo água é geralmente compreendido como recurso natural sem vínculo com qualquer uso ou utilização, entretanto o termo recursos hídricos trata-se da consideração da água como bem econômico, passível de utilização com tal fim. As águas utilizadas para abastecimento humano e de suas atividades socioeconômicas são captadas nos rios, lagos, represas e aquíferos subterrâneos (REBOUÇAS, 1999).

O termo segurança hídrica ganhou destaque em organismos internacionais há alguns anos e começa a ser discutido em âmbito nacional com as crises hídricas no sudeste brasileiro dos anos de 2014 e 2015, envolvendo as metrópoles do Rio de Janeiro e, principalmente, de São Paulo.

O interesse deste trabalho em avaliar a segurança hídrica do abastecimento público de Porto Nacional-Tocantins surgiu da constatação da inexistência de pesquisas ou trabalhos técnicos que analisem a segurança hídrica do município em relação à situação ambiental e ao uso das águas do seu manancial de abastecimento, o Córrego São João, no sentido aqui adotado: garantia de disponibilidade de água, em quantidade e qualidade, para a geração atual e futura.

Esse estudo de caso pode ser também relevante no cenário regional e nacional, porque aborda problemas de abastecimento público de água em município de pequeno porte no Brasil, cujo manancial de abastecimento se situa em região sob pressão da ocupação desordenada e da expansão de fronteiras agrícolas.

De fato, Porto Nacional é um município de pequeno porte, com 52.510 habitantes segundo o Plano Municipal de Água e Esgoto (PMAE) de 2013, e tem vivenciado problemas que estão se tornando frequentes na região, apesar da abundância de recursos hídricos. A pressão antrópica está modificando rapidamente o uso e a ocupação da terra, com fortes impactos sobre o meio ambiente e sobre os recursos hídricos. Com relação à bacia:

1. A bacia tem como principal curso d'agua o Córrego São João, que possibilita atualmente a captação de água para o abastecimento público da população da sede municipal de Porto Nacional; 
2. Localizada no centro-sul do Estado do Tocantins, trata-se de uma sub-bacia de um dos sistemas hidrográficos mais importantes do Brasil, a bacia hidrográfica Tocantins-Araguaia;

3. As matas ciliares que protegem o manancial apresentam sinais de degradação a montante da área represada, onde se situa a captação, em função das atividades agropecuárias;

4. Há expansão do agronegócio no município e em torno da bacia, especialmente pelas lavouras de soja, sem aparente restrição de uso agrícola na bacia; e

5. Há intensa ocupação urbana e empreendimentos de parcelamento do solo no baixo curso da bacia, que estão avançando para o seu trecho médio.

Após levantamento de pesquisas realizadas sobre o córrego São João, constata-se que a intensificação da atividade agrícola e a expansão urbana na bacia favoreceram o avanço da degradação ambiental ao longo dos anos. A falta de planejamento ambiental no uso dessa bacia hidrográfica pode fragilizar a segurança hídrica de seus usuários, interferindo na garantia da qualidade e quantidade de água com os padrões adequados para a manutenção da vida.

A grande dependência do município em relação às águas dessa bacia hidrográfica e a localização vulnerável do ponto de captação de água para abastecimento, por estar em área de expansão agrícola no estado do Tocantins, permite vislumbrar um potencial de conflitos entre a demanda pela quantidade e qualidade da água. A vazão captada atualmente pelo córrego São João atende quase toda a população da sede municipal de Porto Nacional: $99 \%$ da população urbana. (PMAE, 2013).

É nesse contexto que este trabalho se insere, propondo identificar os principais riscos, associados a estressores da bacia do córrego São João, e as principais vulnerabilidades, do Sistema de Abastecimento, que devem ser enfrentados para garantir a segurança hídrica do abastecimento atual e futuro da sede municipal de Porto Nacional.

É importante ressaltar que o município de Porto Nacional possui dois corpos hídricos, intitulados como Córrego São João e Ribeirão São João. Embora o nome dos mesmos sejam trocados frequentemente pelos estudiosos, suas bacias são distintas: enquanto uma possui a área de drenagem de $323,61 \mathrm{~km}^{2}$ e seu rio principal percorre os municípios de Porto Nacional, Monte do Carmo e Palmas, a 
outra bacia, que é o nosso objeto de estudo, compreende $81,99 \mathrm{~km}^{2}$ e se situa quase inteiramente no município de Porto Nacional. Neste trabalho, foi adotada a nomenclatura de Córrego São João em virtude de também ser utilizada no âmbito da Agência Nacional das Águas e do Comitê de Bacias Hidrográficas do Lago de Palmas.

Logo, o estudo se justifica tanto pelo interesse no tema no contexto regional quanto para o próprio estudo de caso. Espera-se que um trabalho como ora apresentado contribua para a tomada de consciência tanto dos gestores da bacia hidrográfica e do sistema de abastecimento, quanto da sociedade em geral, quanto à necessidade de elaboração de estratégias que priorizem a implantação de uma gestão sustentável de recursos hídricos do manancial de abastecimento público da sede municipal de Porto Nacional.

\subsection{Objetos de estudo: bacia do Córrego São João e a ETA 02}

O município de Porto Nacional está localizado na bacia hidrográfica do Rio Tocantins e os seus principais afluentes localizados na zona urbana da cidade, são o Córrego São João, responsável pelo abastecimento de água, e o Córrego Francisquinha, responsável pela diluição dos efluentes tratados na estação de tratamento de esgoto.

A bacia hidrográfica do Córrego São João está inserida na região central do Estado do Tocantins, no município de Porto Nacional, o qual dista $60 \mathrm{~km}$ de Palmas, a capital estadual. De acordo com a Seplan-TO (2008) a bacia hidrográfica do Córrego São João (Figura 1) está localizada entre os paralelos 1046'43" e $10^{\circ} 41^{\prime} 20^{\prime \prime}$ de latitude sul e entre os meridianos 48 $14^{\prime} 16^{\prime \prime}$ e $48^{\circ} 24^{\prime} 51^{\prime \prime}$ de longitude oeste, na porção sudeste do município de Porto Nacional.

A localização do estado do Tocantins, do município e da bacia em estudo, que possui $81,99 \mathrm{~km}^{2}$ de extensão e tem como principal curso d'água o córrego São João, apresentado na figura 1 , por ser um afluente do Rio Tocantins, é um rio de jurisdição estadual. Sua nascente encontra-se nas escarpas da Serra Manoel do Carmo, com sentido SE/NO, com algumas inflexões durante seu curso, até desaguar no reservatório da Usina Hidrelétrica Luís Eduardo Magalhães (Rio Tocantins).

O município de Porto Nacional é o maior em extensão territorial na região do entorno do reservatório da UHE Luís Eduardo Magalhães (Rio Tocantins) e possui $23,43 \%$ da extensão da bacia hidrográfica do entorno do lago. 
FIGURA 1 - Mapa de localização da Bacia Hidrográfica do Córrego São João em Porto Nacional-TO

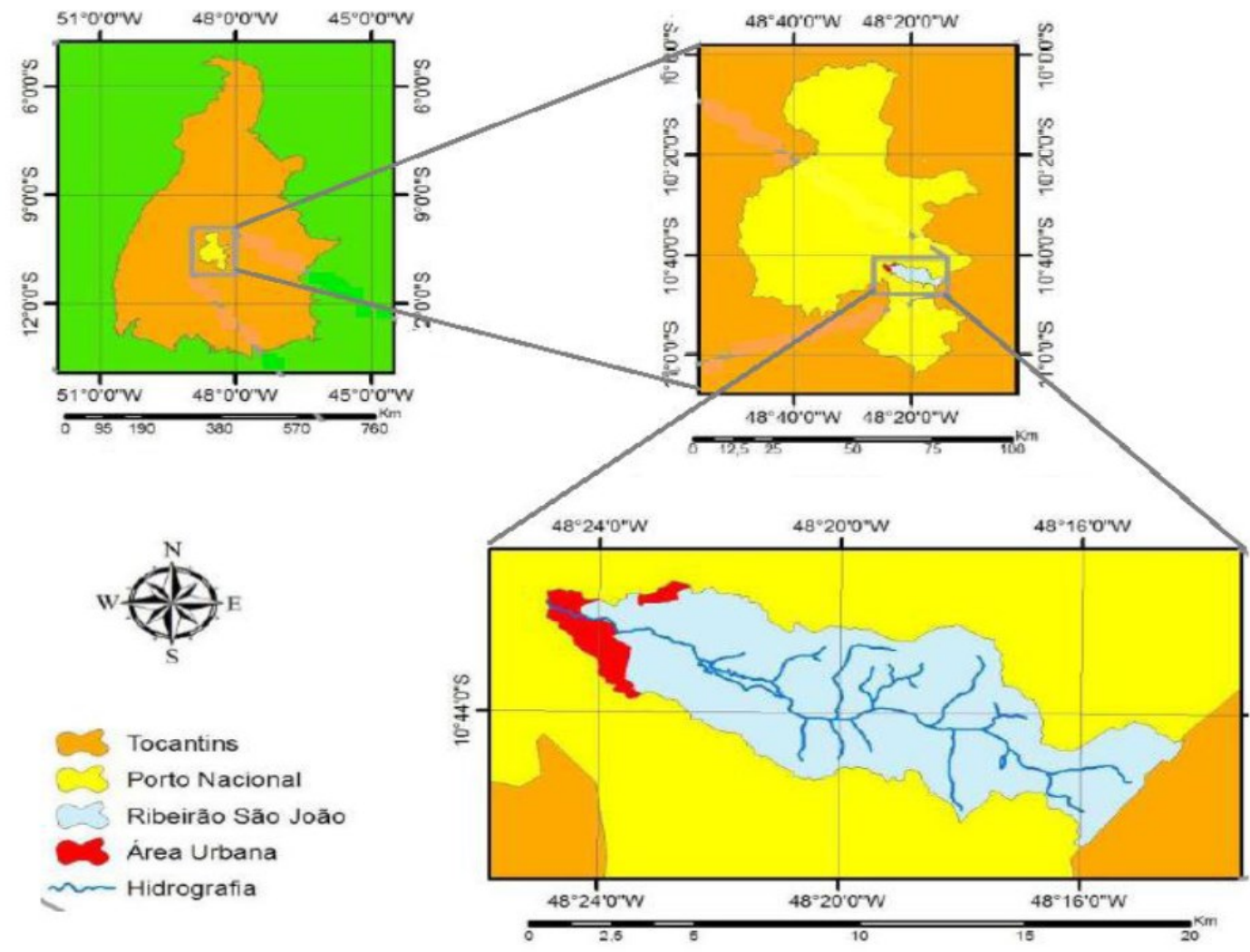

Fonte: Seplan (2008); Silva (2010)

A sede do município de Porto Nacional é atendida por um sistema de abastecimento público operado pela Companhia de Abastecimento de ÁguaSaneatins, a água é captada no Córrego São João por meio de uma barragem de acumulação, onde é bombeada até a estação de tratamento de água, ETA 02, para ser tratada e distribuída. A ETA 02 possui um sistema de dupla filtração, em uma produção total de $170 \mathrm{l} / \mathrm{s}\left(612 \mathrm{~m}^{3} / \mathrm{h}\right)$.

A preocupação com a situação atual da bacia hidrográfica do córrego São João são as transformações ambientais ocorridas, que levaram pesquisadores da UFT a examinarem o uso e a ocupação desta bacia hidrográfica, através de técnicas de sensoriamento remoto que permitiram a confecção de mapas de uso da área da bacia e constataram intensa ocupação da área com agricultura, pecuária e urbanização como principais fatores de degradação ambiental (LEITE e ROSA 2011; CRISTO e NETO 2011). 


\subsection{Objetivos}

A pesquisa tem como objetivo geral avaliar o nível de segurança hídrica do abastecimento público do município de Porto Nacional-TO, em termos de quantidade e qualidade de água bruta do Córrego São João, tendo como referencial a bacia hidrográfica e sua gestão.

Os objetivos específicos incluem:

1. Efetuar uma pesquisa bibliográfica de conceitos básicos relacionados à segurança hídrica;

2. Definir e descrever o modelo conceitual e metodológico para avaliação qualitativa da segurança hídrica de sistemas de abastecimento urbano;

3. Descrever a Bacia Hidrográfica do Córrego São João, suas características ambientais e de uso e ocupação da terra;

4. Descrever o sistema de abastecimento público da sede municipal de Porto Nacional, sobretudo os subsistemas operacionais de captação e tratamento da água bruta;

5. Aplicar o modelo analítico de segurança hídrica para o sistema de abastecimento da sede urbana de Porto Nacional-TO, avaliando os riscos associados à quantidade e qualidade da água bruta, no ponto de captação, e sua compatibilidade com o sistema de abastecimento público, em particular os subsistemas de captação e tratamento.

\subsection{Metodologia de pesquisa}

A metodologia de pesquisa compreende as seguintes etapas não seriadas, mas paralelas, partindo do conceito de segurança hídrica e todos os outros demais conceitos a ele associados nos principais organismos internacionais e nacionais.

Sendo assim, primeiramente, para alcance dos objetivos do estudo, teve-se como ponto de partida uma pesquisa bibliográfica sobre o córrego São João e, nesse percurso, foram identificados vários estudos sobre a bacia do córrego São João. Na sistematização desses estudos foram identificadas 16 pesquisas, entre elas: dissertação de mestrado, artigos e monografias. 
A partir desses produtos foi feita uma caracterização das condições gerais da bacia e a atualização dos dados (usos antrópicos, vazão média, vazão outorgada, dados da qualidade da água, dados de uso da água) e para alcançar os objetivos propostos foram realizadas entrevistas semi-estruturadas junto aos atoreschave envolvidos com a gestão das águas e o abastecimento da água bruta da ETA 02, a saber: NATURATINS, SEPLAN, ITERTINS, MPE-TO, Secretaria Municipal Meio Ambiente, Companhia de Saneamento, proprietários rurais de áreas a montante da captação de água e pesquisadores da UFT e do IFTO. Esse conjunto de informações foi acrescentado à busca de dados junto aos demais órgãos gestores da bacia.

Para avaliação dos usos da terra, inicialmente foram selecionadas imagens de satélite pelo programa Earth Explorer e imagens orbitais (cenas) da constelação de satélites da família Landsat, entre os anos de 2006, 2011 e 2016, grande parte da base vetorial foi adquirida da SEPLAN e o limite da bacia já havia sido gerado anteriormente através do plugin TauDEM instalado no QGIS .

A classificação do uso da terra foi realizada de forma supervisionada, observando-se características de tonalidade, cor, forma e textura na imagem de satélite. Inúmeras técnicas são usadas na interpretação digital com o objetivo de extrair informações sobre o uso da terra, e, de acordo com o programa que se use, as operações podem ser diferentes. No entanto, as mais comuns são as operações de realces, filtragens $\mathrm{e}$ as classificações multiespectrais. No processo de interpretação, dois tipos de classificação podem ser utilizados: não supervisionada e supervisionada, sobre as quais se comentará mais adiante.

Cores, texturas, arranjos e formas são exemplos de características espectrais de feições observadas nas imagens que revelam os alvos imageados, permitindo a identificação de padrões essenciais na interpretação de imagens e a classificação do tipo de Cobertura e de Uso da Terra. Para a interpretação dessas características a utilização das imagens em composição colorida falsa-cor é de grande utilidade para melhor discriminação dos alvos analisados. Nas imagens Landsat utiliza-se frequentemente a composição falsa-cor nas bandas $5 R$, 4G e $3 B$ para as produções de imagens sintéticas por apresentar forte semelhança com as cores da natureza e por facilitar a interpretação da cobertura e do uso da terra.

Além dos materiais citados, foram realizados vários trabalhos de campo para verificação e reconhecimento da área de estudo da bacia hidrográfica do Córrego 
São João seus aspectos e uso e ocupação da terra. Percorreu-se a bacia em estudo pela extensão do curso principal e de alguns afluentes, em ambas as margens, tendo como ponto de partida a barragem de acumulação da companhia de saneamento, até as proximidades da nascente, no seu leito e afluentes, foram realizadas visitas a fazendas, chácaras e sítios para obtenção de informações verbais e observação "in loco" das informações obtidas nos mapas, com levantamento fotográfico terrestre e descrição das características locais (2015 abril/2017).

Para a caracterização do sistema de abastecimento público em relação à qualidade e quantidade de água bruta, além do tipo de tratamento realizado, foram coletados nos documentos oficiais e posteriormente foram aplicados questionários e realizadas entrevistas com funcionários com mais de vinte de anos de serviços prestados à companhia de abastecimento.

Em seguida, baseada na revisão da literatura, desenvolveu-se o modelo analítico de segurança hídrica para uma política de gestão dos recursos hídricos para abastecimentos urbanos com foco na garantia de abastecimento público de Formiga-Johnsson et al (2017), cujo modelo foi aplicado e adaptado para o estudo do caso do Córrego São João. 


\section{CONCEITOS BÁSICOS}

O objetivo desse capítulo é apresentar alguns conceitos sobre segurança hídrica, especialmente de organismos internacionais e nacionais, no sentido de se obter amparo teórico para a pesquisa empírica proposta.

\subsection{Segurança hídrica}

O termo segurança hídrica tornou-se presente no Brasil, principalmente a partir da crise hídrica vivenciada pelo estado de São Paulo e pela região sudeste, em 2014 e 2015, mas esse termo já vem sendo debatido e discutido na academia e em órgãos internacionais, a exemplo da Organização das Nações Unidas (ONU), da Organização para a Cooperação e Desenvolvimento Econômico (OCDE), do Conselho Mundial da Água (World Water Council - WWC) e da Parceria Mundial da Água (Global Water Partnership - GWP).

Desde então, uma profusão de definições e conceitos foram propostos (Melo, 2016), que convergem sobre o tema, mas também geram certa confusão tanto sobre o conceito quanto as possibilidades de medição e gestão da segurança hídrica (Garrick e Hall, 2014).

Ao aprovar um relatório com as principais definições sobre o tema e exemplos da necessidade de discussão em torno dele (ONU, 2013), a instituição ressaltou que faltava uma definição que norteasse tanto as políticas de meio ambiente e saúde, quanto de segurança propriamente dita, focada em operações militares. Ressaltou ainda que um consenso no entendimento da expressão tem uma importância central para a agenda internacional, pois permite colocar todos no mesmo patamar de compreensão e de respostas coerentes aos desafios.

A segurança hídrica é definida pela ONU (2013) como a capacidade de uma população em proteger o acesso sustentável à água, em quantidade e qualidade consideradas aceitáveis, de modo a: atender os meios de subsistência, o bem-estar humano e o desenvolvimento socioeconômico; garantir a proteção contra a poluição e as catástrofes relacionadas à água; e preservar os ecossistemas em um clima de paz e estabilidade política. 
De acordo com a ONU, a definição implica que a água deva ser gerenciada de forma sustentável em todo o ciclo hidrológico, por meio de enfoque interdisciplinar, de modo que contribua para o desenvolvimento socioeconômico, e reforce a resiliência social aos impactos ambientais e às doenças transmitidas pela água, sem comprometer a saúde das populações e dos ecossistemas atuais e futuros (ONU, 2013).

No entendimento da ONU, nos últimos anos, o conceito de segurança hídrica, detém um conjunto de elementos-chave comuns:

1. O acesso à água potável segura e em quantidade suficiente a um custo acessível, a fim de atender as necessidades básicas, que incluem saneamento e higiene e a salvaguarda da saúde e bem-estar;

2. Proteção à vida e aos direitos humanos, a valores culturais e recreativos;

3. Preservação e proteção de ecossistemas;

4. Preservação e proteção dos ecossistemas na alocação e na gestão dos sistemas de água, a fim de garantir a sua capacidade de fornecer e manter a função dos serviços essenciais dos ecossistemas;

5. O fornecimento de água para o desenvolvimento socioeconômico e atividades produtivas (como energia, transportes, indústria, turismo);

6. A coleta e tratamento de água devem ser utilizados para proteger a vida humana e o ambiente contra a poluição;

7. Abordagens colaborativas para gestão de recursos hídricos transfronteiriços dentro e entre países para fomentar a sustentabilidade de água doce e a cooperação;

8. A capacidade de lidar com as incertezas e os riscos de perigos relacionados com a água, tais como inundações, secas e poluição, entre outros; e,

9. Boa governança e "accountability" e a devida consideração aos interesses de todas as partes interessadas, através de: regimes jurídicos adequados e eficazes; instituições transparentes, participativas e responsáveis; infraestrutura devidamente planejada, executada e mantida; e desenvolvimento de capacidades (ONU, 2010).

A agua é vital para a vida e para a saúde da humanidade e dos ecossistemas, sendo um requisito básico para o desenvolvimento de países. Contudo, em todo o mundo, homens, mulheres e crianças não têm acesso à água 
segura para atender às suas necessidades básicas. Por outro lado, as águas e os ecossistemas que as sustentam estão ameaçados de poluição, uso insustentável, mudanças no uso do solo, mudanças climáticas e muitas outras pressões e forçantes (WWC, 20001).

A água deve ser reconhecida como uma grande prioridade. Um dos principais objetivos do Conselho Mundial da Água é aumentar a conscientização sobre o problema da água. Os decisores em todos os níveis devem estar envolvidos. Um dos Objetivos de Desenvolvimento do Milênio (ODM) foi reduzir para metade, até 2015, a proporção de pessoas sem acesso sustentável a água potável e saneamento. Embora esses objetivos não tenham sido alcançados na sua totalidade, a experiência prévia dos ODM (em vigor de 2000 a 2015) apontou que o estabelecimento de objetivos é um eficiente mecanismo para alcançar melhores resultados de desenvolvimento, e que esses compromissos são acompanhados pela ação.

Em setembro de 2015, na Cúpula das Nações Unidas sobre Desenvolvimento Sustentável, foram adotados 17 Objetivos de Desenvolvimento Sustentável, amparados sobre o tripé do desenvolvimento sustentável, que considera as dimensões social, ambiental e econômica de forma integrada e indivisível ao longo de todas as suas 169 metas. O horizonte temporal que os países acordaram para o cumprimento destas metas e objetivos é de 15 anos, sendo 2030 o ano final de vigência dos ODS. Uma das 17 ODS é "Água Potável e Saneamento", que tem como metas:

- Até 2030, alcançar o acesso universal e equitativo à água potável, segura e acessível para todos;

- Até 2030, alcançar o acesso a saneamento e higiene adequados e equitativos para todos, e acabar com a defecação a céu aberto, com especial atenção para as necessidades das mulheres e meninas e daqueles em situação de vulnerabilidade;

- Até 2030, aumentar substancialmente a eficiência do uso da água em todos os setores e assegurar retiradas sustentáveis e o abastecimento de água doce para enfrentar a escassez de água, e reduzir substancialmente o número de pessoas que sofrem com a escassez de água;

\footnotetext{
${ }^{1}$ Disponível em: <http://www.gdrc.org/uem/water/hague-declaration.html>. Acesso em 09 abr. 2017.
} 
- Até 2030, implementar a gestão integrada dos recursos hídricos em todos os níveis, inclusive via cooperação transfronteiriça, conforme apropriado;

- Até 2020, proteger e restaurar ecossistemas relacionados com a água, incluindo montanhas, florestas, zonas úmidas, rios, aquíferos e lagos;

- Até 2030, ampliar a cooperação internacional e o apoio ao desenvolvimento de capacidades para os países em desenvolvimento em atividades e programas relacionados a água e ao saneamento, incluindo a coleta de água, a dessalinização, a eficiência no uso da água, o tratamento de efluentes, a reciclagem e as tecnologias de reuso;

- Apoiar e fortalecer a participação das comunidades locais, para melhorar a gestão da água e do saneamento.

O relatório da OCDE $\left(2013^{2}\right)$, Water Security for Better Lives, propõe uma mudança fundamental na abordagem para enfrentar a segurança da água, aplicável tanto aos países da OCDE como a países não membros da OCDE.

Alcançar os objetivos de segurança da água, segundo a OCDE, significa manter quatro riscos em níveis aceitáveis:

- Risco de escassez (incluindo a seca): água insuficiente para atender a demanda, em curto e longo prazo, de todos os usuários de água (uso humano e urbano, industrial, agropecuário, hidroenergia e demanda ecológica);

- Risco de qualidade inadequada: falta de água com qualidade adequada para os usos preponderantes de um determinado manancial;

- Risco de excesso (incluindo inundações): transbordamento dos limites normais de níveis d'água de um sistema hídrico, natural ou construído, que possam causar desastres;

- Risco de comprometer a resiliência dos sistemas de água doce, ao ultrapassar pontos de inflexão do equilíbrio ecológico e causar danos irreversíveis às funções hidráulicas e biológicas do sistema.

Os quatro riscos devem ser avaliados de forma integrada, pois determinadas intervenções para reduzir um risco podem aumentar outros riscos. Por exemplo,

\footnotetext{
${ }^{2}$ Disponível em: <https://www.oecd.org/env/resources/Water\%20Security\%20for\%20Better\%20Lives\%20brochure.pdf. Acesso em 09 abr. 2017.
} 
fazer derivações e transposições para reduzir o risco de escassez de água pode aumentar o risco de comprometimento da resiliência dos sistemas de água doce. Avaliar o impacto sobre os riscos de água das intervenções políticas (ou a falta dela) exige a pesagem de tais "compromissos de risco-risco".

Uma abordagem baseada em risco aborda a segurança da água em primeiro lugar, determinando níveis aceitáveis de cada um dos quatro principais riscos de água em termos de sua probabilidade e as possíveis consequências (econômicas, ambientais, sociais) e equilibrando isso com os benefícios esperados de melhorar a água segurança. Uma abordagem baseada em risco também permite a identificação de áreas de alto risco, onde as ações políticas devem ser prioritárias.

O Conselho Mundial da Água (Word Water Council - WWF') fundado em 1996 é uma plataforma internacional para desenvolvimento da conscientização e do compromisso político na promoção de ações em questões críticas e estratégicas, em águas.

O Conselho Mundial da Água (WWC, 20004), no ano 2000, conceituou segurança hídrica como: a garantia de proteção e melhoria dos ecossistemas de água doce, costeira e outros relacionados; a promoção do desenvolvimento sustentável e a estabilidade política; acesso à água potável suficiente a um custo acessível para cada pessoa possa levar uma vida saudável e produtiva, e que a população mais vulnerável seja protegida contra os riscos relacionados a água.

Seja qual for o uso de água doce (agricultura, indústria, uso doméstico), uma grande economia de água e melhoria do seu gerenciamento é possível. Quase em todos os lugares, a água é desperdiçada e, enquanto as pessoas não enfrentam escassez de água, permanece a crença de que o acesso à água é óbvio e natural. Com a urbanização e as mudanças no estilo de vida, o consumo de água tem aumentado exponencialmente.

A Global Water Partnership, GWP $\left(2010^{5}\right)$, criada em 1996, é uma rede internacional aberta a todas as organizações envolvidas na gestão de recursos hídricos: país desenvolvido e em desenvolvimento, instituições governamentais, agências das Nações Unidas, bancos biológicos e multilaterais de desenvolvimento,

\footnotetext{
${ }^{3}$ Disponível em: <http://www.worldwatercouncil.org/fileadmin/world_water_council/documents/official_ documents/2013-05_Strategy_2013-2015.pdf>. Acesso em: 09 abr. 2017.

${ }^{4}$ Disponível em: <http://www.gdrc.org/uem/water/hague-declaration.html>. Acesso em 09 abr. 2017.

5 Disponível em: <http://www.gwp.org/Global/About\%20GWP/Annual\%20Reports/GWP\%20in\%20Ac tion\% 20-\%20Annual\%20report\%202010.pdf>. Acesso em: 09 abr. 2017.
} 
associações profissionais, instituições de pesquisa, organizações não governamentais e organizações privadas.

O GWP foi criado para promover a Gestão Integrada de Recursos Hídricos (IWRM), que visa garantir o desenvolvimento e gerenciamento coordenado de recursos hídricos, terrestres e relacionados maximizando o bem-estar econômico e social sem comprometer a sustentabilidade de sistemas ambientais.

O conceito de segurança hídrica tem um grande apelo intuitivo, pois expressa o principal objetivo da gestão da água, que é melhorar a qualidade de vida para todos. É um conceito que fornece aos políticos, líderes empresariais, especialistas de recursos hídricos e diversas disciplinas diferentes e grupos de interesse com uma linguagem comum. A segurança hídrica é um ponto de partida para negociar a complexidade da alocação de recursos hídricos limitados entre muitos concorrentes e muitas vezes demandas conflitantes.

Um mundo seguro de água é aquele em que cada pessoa tem o suficiente seguro, acessível, com água limpa para levar uma vida saudável e produtiva e onde as comunidades encontram-se protegidas de inundações, secas e doenças transmitidas pela água. A segurança hídrica promove a proteção ambiental e a justiça social, abordando a conflitos e disputas que surgem sobre recursos hídricos compartilhados. Isto é a visão da Parceria Global da Água e, nos últimos 20 anos, pesquisadores e os profissionais procuraram entender as questões econômicas, sociais e implicações ambientais de aumentar a segurança hídrica e o que isso significa na prática.

Existe agora um crescente consenso internacional para aumentar a segurança hídrica de maneira sustentável e para construir água mais resiliente e robusta sistemas e, portanto, o conceito de segurança hídrica está evoluindo rapidamente a partir de uma visão para um imperativo de desenvolvimento. No entanto, ainda não há consenso sobre como enquadrar, abordar e operacionalizar o que é um problema real e complexo.

Para a GWP $\left(2010^{6}\right)$ o valor econômico do aumento da segurança hídrica presente nas intervenções de infraestrutura e gestão em sistemas de água são dispendiosas e, portanto, a análise econômica tem que fornecer uma visão dos custos e benefícios das intervenções, comparando o atual "estado do mundo" com algum futuro planejado. Estimar os custos é a parte fácil. Estimar os benefícios

6 Disponível em: <http://www.gwp.org/Global/About\%20GWP/Annual\%20Reports/GWP\%20in\%20Ac tion\% 20-\%20Annual\%20report\%202010.pdf>. Acesso em: 09 abr. 2017. 
requer uma compreensão sólida do valor da água para os usuários, que geralmente é dependente do contexto.

Além disso, algum uso de água geralmente não é totalmente consumível e, portanto, pode ser usado novamente na mesma bacia. Isso faz com que a perspectiva de um Estado (governo), sobre o valor econômico da água, diferente do dos agregados familiares. O Estado deve considerar o valor de todo o sistema, enquanto as famílias apenas olham o valor direto que a água tem para eles. Whittington et al. (2013) fornece uma visão geral desses problemas:

- A segurança da água por si só não pode ser expressa em termos de valor econômico ( $\mathrm{O}$ que os economistas podem fornecer é o valor econômico de se mudar de um nível de segurança da água para outro, ou seja, aumentar a segurança da água);

- Na determinação desse valor econômico, as diferentes perspectivas das famílias e dos Estados devem ser levadas em consideração;

- Um Estado deve considerar cuidadosamente as percepções dos usuários sobre a economia Valor das intervenções de água, na medida em que determinam a utilização dos serviços; E a vontade dos usuários de contribuir financeiramente para investimentos, operações e manutenção (recuperação de custos)

- As decisões individuais sobre os investimentos devem ser consideradas como etapas ao longo Um longo caminho de desenvolvimento da água. Cada decisão deve ser economicamente justificada. Para explicar as incertezas no futuro, a análise de cenários deve ser usada para explorar futuros estados futuros do mundo.

Segundo Melo (2016), o conceito de risco, na literatura de gestão ambiental, designa a combinação entre a probabilidade de ocorrência de um determinado evento e os impactos (positivos ou negativos) resultantes caso ele ocorra (Versilind; Morgan, 2011, Junior; Demajorovic, 2013,

Sanches, 2008, CETESB, 2016, Mitjavila; Grah, 2011). Para a WHO (2009), risco é uma composição de perigo, vulnerabilidade, exposição e capacidade. Simpson et al. (2012), definem o risco em função da vulnerabilidade e da perda, abordando três componentes: a suscetibilidade, o potencial de perigo e as consequências. Já a EPA considera risco como a possibilidade de efeitos nocivos para a saúde humana ou para sistemas ecológicos, resultantes da exposição a um estressor ambiental (EPA, 2016). 
Sendo assim, baseando-se na literatura estudada e nos objetivos deste trabalho, o conceito de risco está associado a impactos potenciais sobre a qualidade e quantidade da água bruta, resultantes da exposição a um ou mais estressores ambientais, que possam vir a afetar o abastecimento público.

No Brasil, o assunto é ainda pouco explorado, tanto pelos estudiosos quanto pelos gestores públicos, e precisa ser discutido. Somente a partir da crise hídrica do Sudeste, em 2014 - que atingiu sobretudo os estados de São Paulo, Rio de Janeiro e Minas Gerais -, o assunto passou a ser mais discutido no meio técnico de recursos hídricos e ganhou prioridade em nível nacional. Foi nessa época que foi adotada uma definição oficial, pelo Thesaurus da ANA (2014), que estabelece dois significados para segurança hídrica:

1. Sua própria definição: "Condição que visa garantir quantidade e qualidade aceitável de água para abastecimento, alimentação, preservação de ecossistemas e demais usos, associados a um nível aceitável de riscos relacionados com a água para as pessoas, economias e meio ambiente" (ANA, 2014, p.34).

2. Definição do Conselho Nacional de Recursos Hídricos - CNRH: "Garantia de disponibilidade hídrica em quantidade e qualidade" (CNRH, 2013, p.34).

As definições acima - de organismos internacionais mais influentes em políticas públicas (ONU, 2010 e 2013; OECD, 2013, Word Water Council, 2000 e 2015; GWP, 2010) evidenciam que o conceito abordado é muito amplo e inclui múltiplas dimensões, envolvendo a gestão de água bruta e serviços de água tratada: água para o consumo humano; água para atividades econômicas; água para os ecossistemas aquáticos; segurança no provimento de serviços de água; gestão do risco de secas; gestão do risco de inundações, entre outros.

A partir de uma extensa revisão bibliográfica, Melo (2016) constatou que o novo paradigma de segurança hídrica, embora emergente, já apresenta vasta literatura e bons resultados práticos de gestão de recursos hídricos em vários países (França, 2009; GTZ, 20107; AAS, 2016\%; EPA, 20169; CEPAL, 2016 ${ }^{10}$; AWDO, 2016 ${ }^{11}$; apud Melo, 2016).

\footnotetext{
7 Disponível em: <http://www.ilo.org/aids/Projects/WCMS_116577/lang--en/index.htm?ssSourceSiteld =global/lang--en/index.htm>. Acesso em: 04 maio 2016 .

${ }^{8}$ Disponível em: <http://aasciences.ac.ke/>. Acesso em: 18 maio 2016.
} 
Neste trabalho, restringiremos o conceito de segurança hídrica segundo a proposta de Formiga-Johnsson et al. (2017), que limita a pesquisa a um único uso (abastecimento público de áreas urbanas) e restringe o conceito de segurança à disponibilidade em termos de quantidade e qualidade de água bruta, conforme detalhado no capítulo 3 , a seguir.

${ }^{9}$ Disponível em: <https://www3.epa.gov/>. acesso em: 18 maio 2016

10 Disponível em: <http://www.cepal.org/es/publicaciones/40074-desafios-la-seguridad-hidricaamerica-latina-caribe>. Acesso em: 06 ago. 2016.

${ }^{11}$ Disponível em: < https://www.adb.org/sites/default/files/publication/189411/awdo-2016.pdf>. Acesso em: 18 ago. 2016 


\section{MODELO CONCEITUAL E METOdOLÓGICO PARA AVALIAÇÃO QUALITATIVA DA SEGURANÇA HÍDRICA NO ABASTECIMENTO PÚBLICO DE ÁREAS URBANAS}

Este capítulo tem por objetivo propor um modelo conceitual e analítico para a avaliação qualitativa do nível de segurança hídrica do abastecimento público de áreas urbanas, em termos de disponibilidade quali-quantitativa de água bruta.

O modelo foi desenvolvido entre maio de 2016 e junho de 2017 no âmbito do Grupo de Pesquisa "Água, Gestão e Segurança Hídrica em tempos de Mudanças Ambientais Globais", sob a coordenação da Prof. Rosa Formiga, da Universidade do Estado do Rio de Janeiro (UERJ/FEN/DESMA), e envolveu uma pesquisadora de doutorado (Marilia Carvalho de Melo, doutorado concluído em dezembro de 2016 pela Universidade Federal do Rio de Janeiro) e dois pesquisadores de mestrado (Millena A. Formiga Dias Bernardeli, mestrado em Geografia pela Universidade Federal do Tocantins; e Phelipe Rabelo da Silva, mestrado em engenharia ambiental pela UERJ; ambos em fase de conclusão) (Formiga-Johnsson et al., 2017).

\subsection{Delimitação do modelo}

Para a construção do modelo de avaliação de segurança hídrica, foram adotados os seguintes recortes:

1. Restringir-se à água bruta, em particular às águas superficiais, concentrandose na gestão ambiental dos recursos hídricos em nível de bacia hidrográfica;

2. Focar em um único usuário de recursos hídricos, a saber, o setor de abastecimento público de água potável em áreas urbanas, mas somente nos seus aspectos que tenham uma relação direta com a água bruta, principalmente os sistemas de captação e tratamento.

Portanto, o conceito de segurança hídrica definido para esta pesquisa é o seguinte:

\footnotetext{
"Segurança hídrica para abastecimento urbano de água pode ser definida como a garantia de provimento de quantidade e qualidade de água bruta que sejam compatíveis com o sistema de abastecimento público, associado a um determinado risco de escassez, tendo como referencial a bacia hidrográfica".
} 
Ressalte-se que uma análise global da segurança do abastecimento de uma determinada área urbana deveria compreender tanto a gestão quali-quantitativa da água bruta quanto a capacidade do serviço de abastecimento público de captar, tratar e distribuir água tratada para toda a população urbana. Ou seja, tal análise deveria compreender todas as etapas relacionadas tanto à água bruta quanto à água tratada, até o consumidor final.

A restrição dessa análise pode ser justificada tanto pela escolha de se manter no setor de gerenciamento de recursos hídricos quanto pelo volume de trabalho e complexidade exigidos por uma avaliação da segurança hídrica envolvendo todas as unidades de um sistema de abastecimento de água potável da captação ao consumidor final. De fato, o setor de abastecimento público, e de saneamento em geral, constitui outro sistema técnico, político e institucional que compreende pesquisas específicas de grande complexidade. Deste setor específico, somente será considerado a parte diretamente relacionada à água bruta, principalmente os sistemas de captação e tratamento.

O desenvolvimento do modelo partiu dos esquemas conceitual e metodológico construídos anteriormente por outros membros do mesmo Grupo de Pesquisa (Raber et al., 2010; e Nogueira, 2011). Estes se basearam sobretudo no conceito de vulnerabilidade, da literatura de mudanças climáticas, e objetivaram avaliar a vulnerabilidade da disponibilidade hídrica de sistemas de abastecimento público perante estressores climáticos e não-climáticos.

Portanto, o modelo analítico, apresentado a seguir, é resultado tanto da evolução do esquema metodológico de referência quanto da construção de uma nova modelagem conceitual e analítica.

\subsection{Modelo para avaliação qualitativa da segurança hídrica de abastecimentos urbanos}

O modelo analítico para avaliação do nível de "segurança hídrica de abastecimentos urbanos" compreende duas partes distintas e complementares (Figura 2):

1. A avaliação do nível de segurança da disponibilidade hídrica de água bruta para o abastecimento urbano, associado a um determinado risco de 
escassez quali-quantitativa, utiliza-se, sobretudo, de quatro componenteschave:

i. Fator de estresse ou estressor sobre as águas e sua bacia hidrográfica, a montante do ponto de captação. Foi definido arbitrariamente um conjunto de cinco estressores, a partir de ampla revisão bibliográfica;

ii. Impactos sobre a qualidade e quantidade de água relacionados ao conjunto dos estressores;

iii. O risco resultante para a quantidade e qualidade de água, em relação a cada estressor considerado; e

iv. Ações de resposta dos sistemas de gerenciamento de recursos hídricos e da gestão ambiental que sejam de maior interesse para a gestão do risco associado à segurança hídrica do abastecimento humano e urbano.

\section{O dimensionamento da vulnerabilidade do sistema de abastecimento} urbano de água relacionado à quantidade e qualidade dos recursos hídricos captados em determinado ponto da bacia hidrográfica, que envolvem sobretudo o sistema de captação e de tratamento, cujas tecnologias devem ser compatíveis com a disponibilidade da água bruta.

É a combinação dessas duas características que determina o nível de segurança hídrica de um determinado sistema urbano de abastecimento, associado a um determinado risco em termos de água bruta, sob o enfoque de uma análise qualitativa (Figura 2).

O modelo tem como resultado principal a "indicação qualitativa do nível de segurança hídrica de um determinado sistema de abastecimento público", visando dar subsídios às políticas públicas envolvidas no provimento de água bruta, em quantidade e qualidade. Para tanto, são consideradas tanto as condições atuais de disponibilidade de água bruta do manancial de abastecimento, e os riscos a ela associados, bem como as capacidades operacionais do sistema urbano de abastecimento público de se adaptar à quantidade e qualidade da água, em termos de captação e tratamento, ou, ainda, de tornar mais racional o uso da água tratada. 
FIGURA 2 - Modelo analítico para avaliação qualitativa de segurança hídrica de sistemas de abastecimento urbano

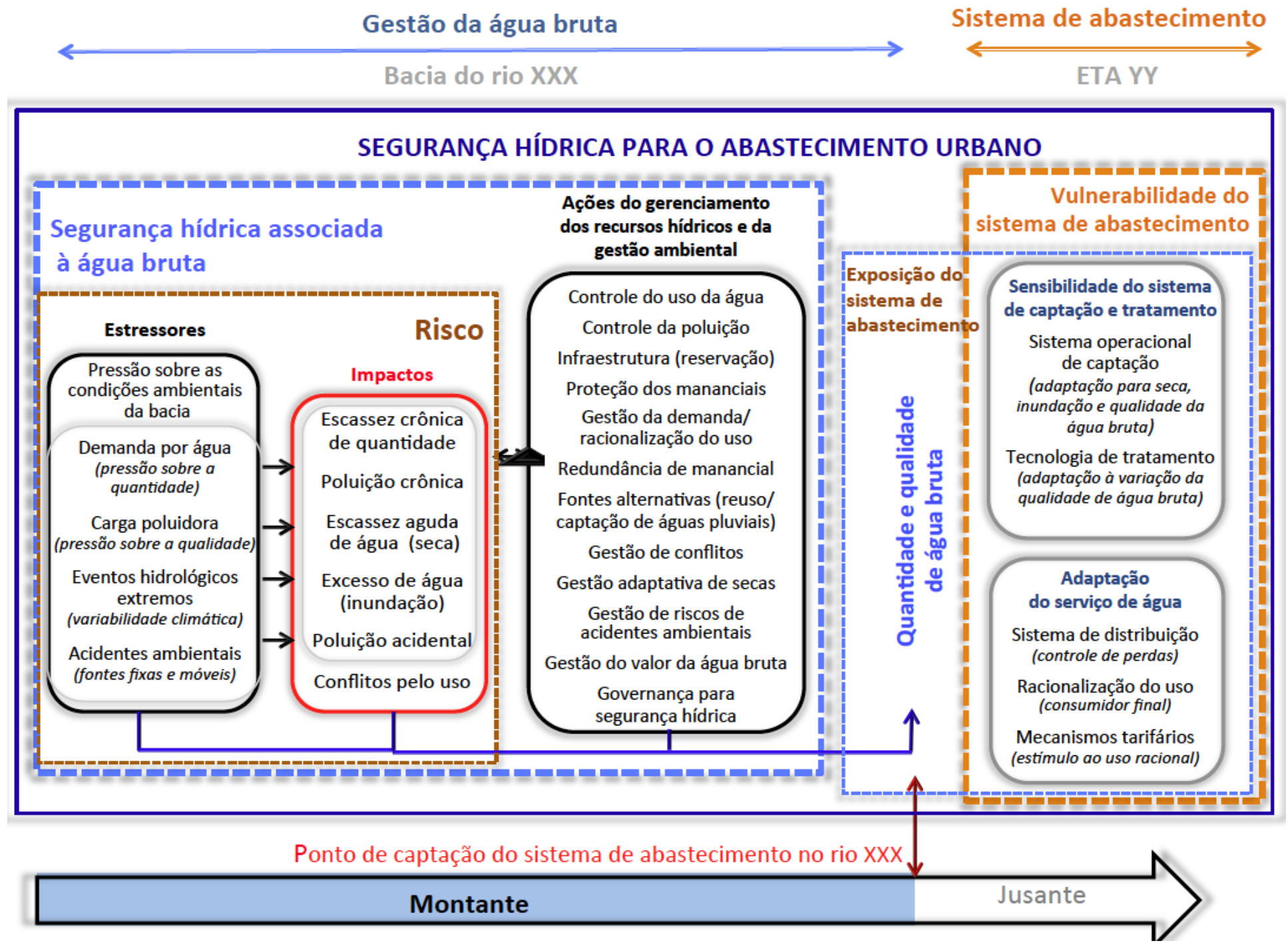

Fonte: Formiga-Johnsson, Melo, Bernardeli e Silva, 2017, a partir de Nogueira (2011) e Raber et al. (2010). 
São apresentadas abaixo as definições básicas que compõem o modelo analítico, especialmente customizadas para o conceito de segurança hídrica adotado neste trabalho tendo por base a extensa revisão bibliográfica:

- Risco é a probabilidade de ocorrência de impactos sobre a quantidade ou qualidade da água bruta, resultantes de efeitos combinados de estressores sobre o manancial e sua bacia hidrográfica, que podem acarretar prejuízos à segurança hídrica do abastecimento público. Neste trabalho, o risco foi avaliado de forma qualitativa (riscos aceitáveis, toleráveis e inaceitáveis).

- Estressor é o fator que pode induzir a estresses e impactos sobre a quantidade ou qualidade da água bruta no ponto de captação, podendo pressionar ou afetar o sistema de abastecimento público nos seus componentes de captação e tratamento.

- Impacto é aqui definido como resultado da severidade da ação de um ou mais estressores sobre a quantidade e qualidade das águas de uma bacia hidrográfica, em função da magnitude e ocorrência de estressores, isolada ou simultaneamente, e das intervenções que visam prevenir, mitigar ou gerir os efeitos dos estressores;

- Vulnerabilidade de um sistema (neste caso, o sistema de abastecimento urbano de água) está relacionada à sua exposição às condições da água bruta no ponto de captação, resultante das ações dos estressores e da gestão a montante da bacia hidrográfica, que pode impactar a água tratada. $\mathrm{A}$ vulnerabilidade foi também avaliada de forma qualitativa (alta, média e baixa).

- Ações de gestão compreendem as intervenções tanto do sistema de gerenciamento de recursos hídricos quanto do sistema de gestão ambiental, que permitam prevenir, mitigar ou controlar os efeitos/impactos dos estressores sobre a água bruta. Busca-se manter os riscos associados aos diferentes estressores em níveis aceitáveis de segurança hídrica para o abastecimento humano, em termos de quantidade e qualidade de água bruta. 


\subsection{Definição de estressores, impactos e ações de gestão na bacia hidrográfica}

A segurança hídrica para abastecimento público de uma determinada área urbana, em termos de quantidade e qualidade de água bruta, é baseada no conhecimento dos estressores e seus impactos, dos padrões de ocorrência e da probabilidade de risco a eles associados, em toda a área de influência da bacia hidrográfica, a montante do ponto de captação.

\subsubsection{Estressores}

A escolha dos estressores foi baseada na revisão da literatura e em longas discussões com o Grupo de Pesquisa sobre quais estressores mais influenciam a segurança hídrica na maioria dos casos das áreas urbanas brasileiras. Foram selecionados os seguintes:

- Pressão sobre as condições ambientais na bacia hidrográfica que pode alterar a quantidade e qualidade de água e está relacionada às características físicas da bacia e ao uso e ocupação do solo, cobertura vegetal, entre outros.

- Demanda por água (pressão sobre a quantidade), que é caracterizada pelos usos de água, consuntivos e não consuntivos, a montante da captação (uso urbano, uso industrial, irrigação, dessedentação de animais, hidroenergia, mineração e outros).

- Carga poluidora (pressão sobre a qualidade), que está diretamente relacionada às condições ambientais da bacia, e às fontes de degradação da qualidade das águas (esgotamento sanitário, lançamento de efluentes industriais, agrotóxicos, disposição dos resíduos sólidos, etc.).

- Eventos hidrológicos extremos (variabilidade climática), que podem resultar em estiagens severas/secas e inundações.

- Acidentes ambientais, que podem ser provenientes de fontes fixas (acidentes industriais) e móveis (acidentes em ferrovias e rodovias), a montante do ponto de captação.

A caracterização que segue de cada estressor, nesta seção, foi baseada em Melo (2016). 


\subsubsection{Pressão sobre as condições ambientais da bacia hidrográfica}

A bacia hidrográfica está sujeita a pressões antrópicas, que podem alterar suas condições ambientais, com efeitos na quantidade e na qualidade das águas. $\mathrm{A}$ vulnerabilidade da bacia a esse estressor depende, de um lado, de suas características originais (geologia, topografia, cobertura vegetal) e, de outro lado, da ocupação da terra tal como urbanização, indústria, mineração e agricultura.

Outra característica é a intensidade $\mathrm{e}$ as áreas atingidas pelo desmatamento, que aumenta a velocidade de run-off e diminui a taxa de infiltração no solo. O desmatamento, em geral, desprotege o solo, o que propicia erosão e assoreamento dos cursos de água, tendo impactos exacerbados sobre as águas quando se trata de APPs hídricas (margens de rios e nascentes).

Em curto prazo, a ação desse estressor é sentida principalmente sobre a qualidade das águas da bacia hidrográfica e do manancial. Ao longo do tempo, o estressor pode levar a situações em que a quantidade de água disponível e alteração do regime de escoamento é diminuída pela impermeabilização e consequentemente há um aumento da velocidade de escoamento.

\subsubsection{Demanda por água (pressão sobre a quantidade)}

A variabilidade quantitativa é inerente a qualquer sistema de água em condições naturais. Ela é função do regime hidrológico anual, que determina as vazões sazonais disponíveis nos corpos de água, com disponibilidade maior no período de chuva e menor no período de estiagem. Por sobre as condições naturais, que impõem variabilidade à quantidade disponível, frequentemente ocorre o crescimento da demanda como função da dinâmica do desenvolvimento econômico e do crescimento populacional em áreas urbanas na bacia.

A demanda por água, por parte de todos os usuários consuntivos, estressa quantitativamente o manancial, de maneira proporcional à demanda, pois diminui o balanço hídrico da bacia, sobretudo os usos consuntivos (usos urbano, agrícola, industrial e dessedentação de animais, entre outros). Este estressor afeta também a qualidade das águas, visto que a diminuição do volume remanescente reduz a capacidade de auto-depuração. 
Em casos extremos, este estressor pode se apresentar sob a forma de conflitos pelo uso da água bruta, quando a relação disponibilidade-demanda se aproxima dos seus limites. Em situações de escassez, a prioridade legal é o abastecimento humano e dessedentação de animais.

\subsubsection{Carga poluidora (pressão sobre a qualidade da água)}

Carga poluidora é aqui considerada como aquela continuamente lançada na bacia, constituindo, portanto, um estressor que pode resultar na deterioração da qualidade da bacia hidrográfica e do manancial. Os poluentes são aqueles oriundos de lançamentos, pontuais e difusos, de carga poluidora com origem principalmente nos esgotos sanitários, nos efluentes industriais, na aplicação de agrotóxicos e na disposição dos resíduos sólidos. O impacto do estressor é função direta da intensidade com que ocorre.

A expansão urbana desordenada, agravada pelo tradicional descaso com o lançamento de efluentes industriais e domésticos in natura no meio ambiente, é um determinante das origens desse estressor.

Em geral, os lançamentos se concentram em um espaço restrito do território, o que produz um impacto cumulativo de sucessivos lançamentos no corpo de água. Considerando a capacidade de auto-depuração ou capacidade de suporte de um corpo de água, que representa a sucessão ecológica, o adensamento de lançamentos pode enfraquecer ou debilitar a resiliência dos sistemas de água doce (OCDE, 2013; von Sperling, 2007 apud Melo, 2016). Assim, as águas de muitos rios urbanos tornam-se impróprias para o abastecimento público por causa da degradação da qualidade, ou devido a altos custos de tratamento.

\subsubsection{Eventos hidrológicos extremos}

Os eventos hidrológicos extremos aqui considerados são os períodos de estiagem acentuada/secas ou de chuvas intensas. $O$ estressor pode perturbar a segurança hídrica tanto quantitativa, quanto qualitativamente.

Já é sabido que o comportamento hidrológico caracteriza-se naturalmente por variações sazonais. Em períodos de estiagem severa ou prolongada, há uma diminuição da disponibilidade de água, em quantidade e, por vezes, há o comprometimento em alguns parâmetros que descrevem a qualidade. Por causa da 
natureza do estressor, a severidade do impacto de uma estiagem sobre a segurança hídrica é mais significativa em termos da quantidade do que da qualidade da água.

Inundação é o fenômeno caracterizado pelo transbordamento de água de calha normal de um curso d'água, ou pela acumulação de água, por drenagem, em áreas não habitualmente submersas (UNESCO, 1983, apud ANA, 2015), que pode afetar a segurança hídrica por causa da deterioração da qualidade da água, do comprometimento da integridade física e operacional do subsistema de captação ou até mesmo da planta de tratamento (Melo, 2016).

\subsubsection{Acidentes ambientais}

Tal como os ordinários, os poluentes acidentais podem comprometer a qualidade das águas do manancial. Também como no caso dos poluentes ordinários, o impacto do estressor é função direta da intensidade com que ocorre. Os poluentes acidentais podem ser provenientes de fontes fixas, como é o caso do lançamento irregular, proposital ou não, de efluentes industriais, minerários, entre outros, ou de fontes móveis, como é o caso de cargas poluidoras oriundas de acidentes com meios de transporte.

Em resumo, o estressor surge como consequência de qualquer evento anormal, indesejado e inesperado, com potencial para causar danos diretos ou indiretos à saúde humana, ao meio ambiente ou a outro bem a proteger (CETESB, 2003).

A ocorrência do estressor depende da existência de atividades ou estruturas fixas propensas a provocar acidentes ambientais, e também depende da proximidade do manancial com vias terrestres ou fluviais de transporte.

Ambos os estressores, poluentes ordinários e acidentais, provocam a degradação da qualidade da água bruta, cuja extensão pode ser avaliada por comparação de valores determinados para os parâmetros de qualidade do corpo de água com os padrões da Resolução CONAMA 357/2005).

\subsubsection{Impactos: definições}

Aos impactos associados aos estressores, apontados anteriormente, foram definidos seis riscos associados aos estressores (Formiga-Johnsson et al., 2016), a saber: 
- Escassez crônica de quantidade, caracterizada pela "falta ou insuficiência de água" (ANA, 2015), em quantidade, que ocorre em 'tempos normais' (sem extremos climáticos) quando a demanda quantitativa por água excede ou se encontra próximo do limite da oferta da disponibilidade de água doce superficial e subterrânea, em uma determinada unidade hidrológica.

- Poluição crônica, caracterizada pela "falta ou insuficiência de água" (ANA, 2015), em qualidade apropriada para o consumo humano, mesmo havendo disponibilidade quantitativa de água, conforme regulamentação da Resolução CONAMA 357/2005 que "dispõe sobre a classificação dos corpos de água e diretrizes ambientais para o seu enquadramento" (alterada pela Resolução 410/2009 e pela 430/2011).

- Escassez aguda de água (seca): a estiagem é um fenômeno natural que ocorre quando há um período de tempo sem a ocorrência de chuvas (ANA, 2015). Quando a estiagem é severa ou prolongada (seca), há uma diminuição da disponibilidade de água, em quantidade e também às vezes em qualidade, que pode causar escassez de água e impactar o abastecimento humano e os usos múltiplos.

- Excesso de água (inundação), caracterizada pelo "transbordamento de água de calha normal de um curso d'água ou acumulação de água, por drenagem, em áreas não habitualmente submersas" (UNESCO, 1983, apud ANA, 2015), que pode afetar o abastecimento humano através da deterioração da qualidade de água, do impacto sobre o sistema de captação de água e até mesmo da planta de tratamento.

- Acidentes ambientais, de origem tecnológica, associados à poluição acidental das águas causadas por fontes fixas industriais ou móveis (transporte de cargas perigosas em ferrovias e rodovias) que podem causar a interrupção do sistema de captação para abastecimento público. Foi considerado como "acidente ambiental qualquer evento anormal, indesejado e inesperado, com potencial para causar danos diretos ou indiretos à saúde humana, ao meio ambiente ou a outro bem a proteger" (CETESB, 2003, apud Nogueira, 2011).

- Conflitos pelo uso, decorrentes dos usos múltiplos das águas superficiais e subterrâneas e do uso e ocupação do solo, associados ao desenvolvimento socioeconômico na bacia hidrográfica. 


\subsubsection{Ações de gestão}

As ações de gestão foram aqui consideradas como intervenções tanto do sistema de gerenciamento de recursos hídricos, instituídos pelas leis federal 9.433/97 e leis estaduais, quanto do sistema de gestão ambiental que compreende uma vasta gama de ações, desde a biodiversidade e áreas protegidas às mudanças climáticas, passando pelo controle da poluição. Elas compreendem todas as ações relacionadas à prevenção, mitigação ou controle dos efeitos dos estressores sobre a água bruta, visando garantir que os riscos associados à segurança hídrica - ou seja, à disponibilidade quali-quantitativa para o abastecimento público - permaneçam em níveis aceitáveis.

As ações de gestão podem ser assim apreendidas como gestão do risco, cujo objetivo é prevenir, mitigar e controlar os riscos, devendo agir sobre os estressores a fim de controlar ou minimizar a exposição ao fator que pode induzir um efeito adverso na quantidade e na qualidade da água bruta utilizada para o abastecimento urbano.

Baseada na revisão bibliográfica e na experiência prática dos pesquisadores do Grupo de Pesquisa, Formiga-Johnsson et al. (2017) elencaram 11 ações como sendo de maior interesse para a segurança hídrica em termos de quantidade e qualidade de água bruta, que podem ser agregadas em ações operacionais de gerenciamento (itens 1 a 7) e ações institucionais de gestão e governança das águas (8 a 11):

1. Controle do uso da água;

2. Controle da poluição;

3. Infraestrutura (reservação);

4. Proteção dos mananciais;

5. Gestão da demanda/ racionalização do uso;

6. Redundância de manancial (fonte de água bruta);

7. Fontes alternativas (reuso/captação de águas pluviais);

8. Gestão de conflitos;

9. Gestão adaptativa de secas;

10. Gestão de risco de acidentes ambientais;

11. Governança para segurança hídrica. 


\subsection{Avaliação qualitativa do risco associado à segurança hídrica do abastecimento urbano}

\subsubsection{Avaliação qualitativa de risco associada a cada estressor}

As propriedades dos estressores que influem diretamente na medida do risco, consideradas neste estudo, são a severidade do impacto e a probabilidade de ocorrência dos estressores. Riscos maiores correspondem a impactos mais severos e a maiores probabilidades de ocorrência do estressor.

A severidade do impacto e a probabilidade de ocorrência dependem das características do ambiente antrópico e do ambiente natural em que se insere a bacia hidrográfica, e da recorrência observada. Em muitos casos, ainda não estão estabelecidos modelos físicos e matemáticos capazes de permitir a avaliação, a exemplo da probabilidade de ocorrência do estressor "pressão sobre as condições ambientais" (Melo, 2016); em casos como esse, os graus das propriedades podem ser razoavelmente arbitrados pelo gestor da bacia hidrográfica. Em outros casos, a exemplo da Bacia do Córrego São João, não há dados, em quantidade e medidos com frequência suficiente para permitir a avaliação das propriedades de um estressor ou de um conjunto de estressores.

O Quadro 1 apresenta os critérios empregados para atribuir graus às propriedades dos estressores. Para cada propriedade dos estressores, foi adotada uma graduação de três níveis para efeito de avaliação qualitativa de riscos: baixo, moderado e alto. A escolha da escala com apenas três graus é também coerente com a realidade da bacia de estudo, que tem pouca disponibilidade de dados e informações precisas sobre suas condições ambientais e dos recursos hídricos.

QUADRO 1 - Graduação qualitativa dos estressores, por propriedade

\begin{tabular}{|c|l|c|}
\hline \hline GRADUAÇÃO & OCORRÊNCIA DO ESTRESSOR & SEVERIDADE DO IMPACTO \\
\hline \hline Baixo & \multicolumn{1}{|c|}{ Casos isolados } & $\begin{array}{c}\text { Definido de acordo com } \\
\text { os indicadores específicos, } \\
\text { apresentados adiante (item } \\
\text { Moderado }\end{array}$ \\
\cline { 1 - 2 } Alto & $\begin{array}{l}\text { Ocorrência irregular, ou regular } \\
\text { segundo padrões sazonais }\end{array}$ & \\
\hline \hline
\end{tabular}

Fonte: Melo, 2016. 
De forma bem simplificada, pode-se combinar de forma matricial os três graus qualitativos atribuídos às propriedades dos estressores, resultando em nove medidas possíveis de risco, por estressor. Para graduar o risco resultante na matriz, tomou-se por referência OCDE (2013) que agrupou os riscos de acordo com o seu nível: aceitáveis, toleráveis e inaceitáveis (Figura 3).

FIGURA 3 - Matriz de determinação do grau de risco, por estressor

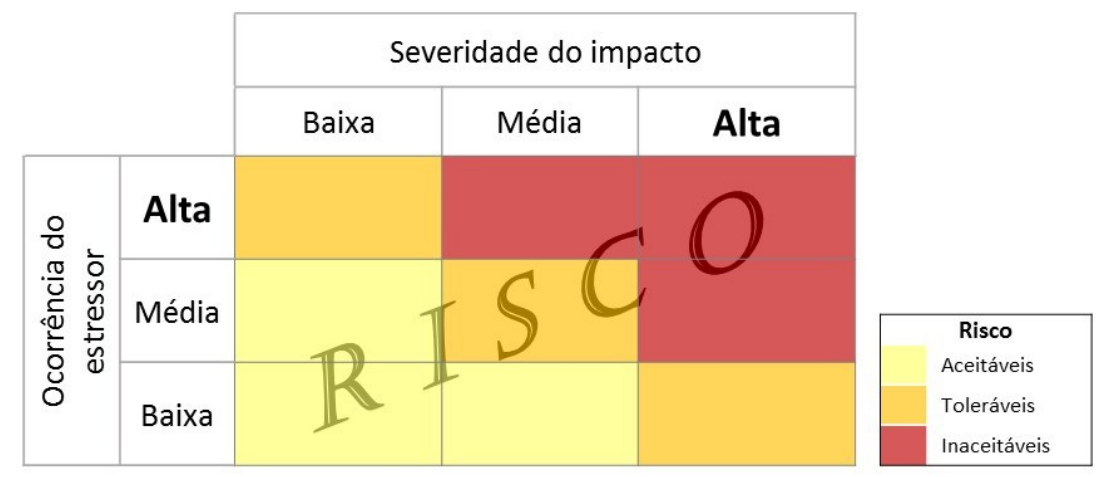

Essa graduação é também uma forma simples e direta de indicar as prioridades de gestão para fins de segurança hídrica, em geral, e do abastecimento urbano, em particular. Os riscos aceitáveis requerem sobretudo ações de monitoramento de seu comportamento, por meio das características mensuráveis do estressor, e de ações preventivas de planejamento e gestão. Em contrapartida, ações são necessárias para reduzir um risco com nível tolerável para o nível aceitável; no extremo, riscos intoleráveis requerem ações urgentes para reduzi-los a um nível aceitável devido a sua probabilidade muito elevada ou seu alto potencial de dano (OCDE, 2013).

\subsubsection{Severidade do impacto de estressores}

A ação dos estressores sobre a fonte de água bruta pode provocar dois efeitos: o estresse quantitativo e o estresse qualitativo, cujo impacto depende da intensidade da ação do estressor.

O grau de severidade indica que o impacto produzido por um estressor ou pela combinação de vários estressores pode alterar a quantidade e a qualidade da água bruta com intensidade correspondente. 


\subsubsection{Severidade do impacto sobre a quantidade}

O impacto sobre a quantidade de água na bacia hidrográfica e no manancial é resultado da ação de 3 estressores: pressão sobre as condições ambientais, demanda por água e eventos hidrológicos extremos.

\section{(a) Estressor "pressão sobre as condições ambientais da Bacia"}

Este estressor foi o mais desenvolvido e explorado, no âmbito desta dissertação, em função da disponibilidade de dados e estudos dispersos, globalmente mais favoráveis quando comparado aos demais estressores. Além de uma ampla caracterização da Bacia, foram escolhidos três indicadores-chave:

- Uso e ocupação da terra (Área antropizada);

- Desmatamento da cobertura vegetal na bacia (Área desmatada na totalidade da bacia); e

- APPs hídricas degradadas (APP-fluvial e APP- nascentes sem cobertura vegetal).

\section{(b) Estressor "demanda por água"}

Em termos quantitativos, um índice de estresse hídrico pode ser expresso de diferentes maneiras (por exemplo: Gleick, 1996; Raskin, et al., 1997; Fernandes, 2002; ANA, 2009; McNulty et al., 2010; apud Melo, 2016).

Neste trabalho, o indicador finalístico será o percentual de comprometimento da vazão outorgável, disponível no Plano da Bacia Hidrográfica do Entorno do Lago (FAPTO, 2016) que fez o cálculo do balanço hídrico para avaliar o comprometimento da disponibilidade hídrica da Bacia do Córrego São João.

\section{(c) Eventos hidrológicos extremos (seca)}

Diante da inexistência do monitoramento das águas do Córrego São João e de estudos com registros de extremos de estiagem severa/seca, este estressor foi avaliado de forma qualitativa, a partir de relatos de ribeirinhos e técnicos que trabalham com a Bacia sobre a ocorrência e frequência deste extremo hidrológico. 


\subsubsection{Severidade do impacto sobre a qualidade}

Informações sobre a qualidade das águas do Córrego São João são raras e pontuais. Por essa razão, este estressor foi avaliado de maneira qualitativa, buscando, de um lado, a identificação de fontes poluidoras (ocorrência do estressor) e, de outro lado, a avaliação disponível da qualidade das águas da Bacia que é o indicador do impacto das diferentes fontes poluidoras, pontuais e difusas, sobre os recursos hídricos.

3.4.2.3 Resumo dos indicadores relativos ao impacto dos estressores sobre as águas da Bacia

O Quadro 2 apresenta um resumo dos estressores da fonte de água bruta, suas características mensuráveis e os parâmetros que os quantificam, que foram adaptados para esta pesquisa, sobre a Bacia do Córrego São João. 
QUADRO 2 - Estressores de água bruta selecionados para compor o modelo analítico de avaliação da segurança hídrica do abastecimento urbano

\begin{tabular}{|c|c|c|c|c|}
\hline \multicolumn{2}{|r|}{ Estressor } & $\begin{array}{c}\text { Característica mensurável } \\
\text { (quantitativa ou qualitativamente) }\end{array}$ & Indicador & Unidade \\
\hline \multirow{3}{*}{1} & \multirow{3}{*}{$\begin{array}{c}\text { Pressão } \\
\text { sobre as } \\
\text { condições } \\
\text { ambientais da } \\
\text { bacia }\end{array}$} & Uso e ocupação da terra & Área antropizada & \multirow{3}{*}{$\begin{array}{c}\text { hectares } \\
\text { e } \\
\text { \% em } \\
\text { relação } \\
\text { ao total }\end{array}$} \\
\hline & & $\begin{array}{l}\text { Desmatamento da cobertura } \\
\text { vegetal na bacia (exceto Áreas de } \\
\text { Preservação Permanente - APPs) }\end{array}$ & $\begin{array}{l}\text { Área desmatada na } \\
\text { totalidade da bacia }\end{array}$ & \\
\hline & & APPs hídricas degradadas & $\begin{array}{l}\text { APP-fluvial e APP- } \\
\text { nascentes } \\
\text { cobertura vegetal }\end{array}$ & \\
\hline \multirow[b]{2}{*}{2} & \multirow{2}{*}{$\begin{array}{l}\text { Demanda } \\
\text { por água } \\
\text { (pressão sobre } \\
\text { a quantidade) }\end{array}$} & Usos atuais e usuários da água & $\begin{array}{l}\text { Vazão estimada e } \\
\text { outorgada }\end{array}$ & $\mathrm{m}^{3} / \mathrm{s}$ \\
\hline & & Disponibilidade hídrica atual & Balanço hídrico & $\begin{array}{l}\mathrm{m}^{3} / \mathrm{s} \text { e } \\
\% \text { em } \\
\text { relação } \\
\text { ao total }\end{array}$ \\
\hline 3 & $\begin{array}{l}\text { Carga } \\
\text { poluidora } \\
\text { (pressão sobre } \\
\text { a qualidade) }\end{array}$ & \multicolumn{2}{|c|}{$\begin{array}{l}\text { Avaliação qualitativa e pontual, } \\
\text { de acordo com registros e estudos existentes. }\end{array}$} & - \\
\hline 4 & $\begin{array}{l}\text { Eventos } \\
\text { hidrológicos } \\
\text { extremos }\end{array}$ & \multicolumn{2}{|c|}{ Registros e memórias de secas e inundações } & - \\
\hline 5 & $\begin{array}{l}\text { Acidentes } \\
\text { ambientais }\end{array}$ & \multicolumn{2}{|c|}{ Identificação de potenciais fontes fixas e móveis } & - \\
\hline
\end{tabular}

Fonte: A autora.

\subsection{Vulnerabilidade do sistema de abastecimento urbano perante sua exposição ao risco associado à água bruta}

A avaliação de segurança hídrica, conforme recorte desta pesquisa, se limita às questões da água bruta, envolvendo, de um lado, a gestão dos recursos hídricos do manancial de abastecimento, no contexto da bacia hidrográfica, e, de outro lado, o próprio sistema de abastecimento público naquilo que envolve diretamente a água bruta, em particular sua vulnerabilidade, objeto desta seção. 


\subsubsection{Conceitos}

A vulnerabilidade de um determinado sistema de abastecimento urbano perante à água bruta pode ser avaliada de forma qualitativa, tendo por base a equação desenvolvida por Yohe e Tol (2002), e adaptada por Engle e Lemos (2007), que parte do conceito de vulnerabilidade às mudanças climáticas, ou outra ameaça, como intrinsecamente ligado a capacidade de adaptação (Formiga-Johnsson, 2011):

$$
V=f\{E(A C) ; S(A C)\}
$$

Onde:

- V é vulnerabilidade,

- E é o grau de exposição ao estresse,

- S é o grau de sensibilidade ao estresse e

- AC é capacidade da adaptação.

Vulnerabilidade de um sistema a uma ameaça é, portanto, função do seu grau de exposição e grau de sensibilidade aos estresses a elas relacionados bem como do nível de capacidade de adaptação desse sistema a essas mudanças. Nesta pesquisa, a vulnerabilidade do sistema de abastecimento urbano de água foi definida como função do seu grau de exposição e do seu grau de sensibilidade aos riscos relacionados à água bruta, bem como da sua capacidade adaptativa às variabilidades de quantidade e qualidade da água no ponto de captação, no contexto da gestão da bacia hidrográfica ${ }^{12}$.

Para os autores, a exposição é vista como a natureza e o grau em que um sistema experimenta estresses ambientais ou político-sociais, ou seja, diz respeito à natureza, magnitude, frequência, duração e extensão de um estressor ou ameaça (estresse climático, por exemplo) sobre uma determinada unidade de análise. № presente trabalho, a ameaça ao qual o sistema de abastecimento está exposto refere-se ao risco relacionado à disponibilidade de água bruta no ponto de captação de água, no contexto da gestão da bacia hidrográfica, tanto em termos de quantidade (seca ou inundação) quanto de qualidade.

12 Grifo nosso. 
A sensibilidade é encarada como o grau em que um sistema é afetado ou como ele vai responder aos estresses, seja de forma positiva ou negativa. Assim, $\underline{a}$ sensibilidade de um sistema, neste estudo, é uma resultante de características operacionais dos sistemas de captação e tratamento, que podem ser mais ou menos sensíveis à variação do nível do corpo d'água, em momentos de estiagem e inundação, ou à qualidade dos recursos hídricos do manancial de abastecimento, respectivamente.

Por sua vez, a literatura teórica identifica várias categorias de determinantes que influenciam a capacidade de um sistema adaptar-se positivamente a diferentes estresses, incluindo: recursos econômicos, tecnologia, informação e capacidades, infra-estrutura, instituições e governança. A adaptação, neste trabalho, refere-se sobretudo à determinadas características do serviço de abastecimento e sua gestão que lhe permitem ser mais adaptativo - e consequentemente menos sensível - à eventuais problemas de disponibilidade de água bruta (por exemplo, sistemas móveis de captação ou barragens de captação).

\subsubsection{Metodologia de avaliação da vulnerabilidade}

A vulnerabilidade do sistema de abastecimento será determinada de acordo com a fórmula de Yohe e Tol (2002), adaptada por Engle e Lemos (2007) e utilizada por Raber et al. (2010) e Nogueira (2011):

- A exposição da Estação de Tratamento de Água se refere à localização geográfica do ponto de captação de água bruta, que determina a quantidade e qualidade de água disponível no ponto de captação, associado a determinado risco.

- A sensibilidade da ETA que é vista como o componente interno da vulnerabilidade, ou seja, são as propriedades ou atributos inerentes ao sistema analisado. Estas propriedades indicam de que forma e intensidade 0 sistema é afetado, ou seja, de que maneira ele sente a exposição, o que, por sua vez, depende de sua capacidade de adaptação, a saber:

- Subsistema de captação, que pode ser mais ou menos adaptativo às variações do nível do rio, sobretudo durante eventos de seca e inundação: captação fixa ou móvel; a fio d'água ou com reservação; se tem proteção contra correntezas e inundações; 
- Subsistema de tratamento, se tem tecnologia suficientemente robusta para absorver variações de qualidade da água bruta, durante situações de normalidade hidrológica, secas e inundações: simples desinfecção; convencional - gradeamento, floculação, decantação, filtração e desinfecção -; e tratamento avançado, que emprega tecnologias como membranas de osmose reversa e carvão ativado. A segurança hídrica das instalações contra inundações também é um fator importante de sensibilidade.

- Subsistema de distribuição, se existem medidas que possam diminuir a pressão do consumo urbano sobre o manancial de abastecimento: redução de perdas físicas e desperdício de água; e medidas de estímulo à indução ao uso racional da água tratada por parte do consumidor final.

Conforme recorte adotado, a avaliação se limita às questões de interesse direto ou que possa impactar a gestão da água bruta (Figura 4). Então não serão analisadas todas as demais questões inerentes ao sistema de distribuição, operação e manutenção do serviço de abastecimento que possam afetar o abastecimento de água potável para a população. 
FIGURA 4 - Modelo analítico de segurança hídrica: Vulnerabilidade do sistema de abastecimento urbano de água

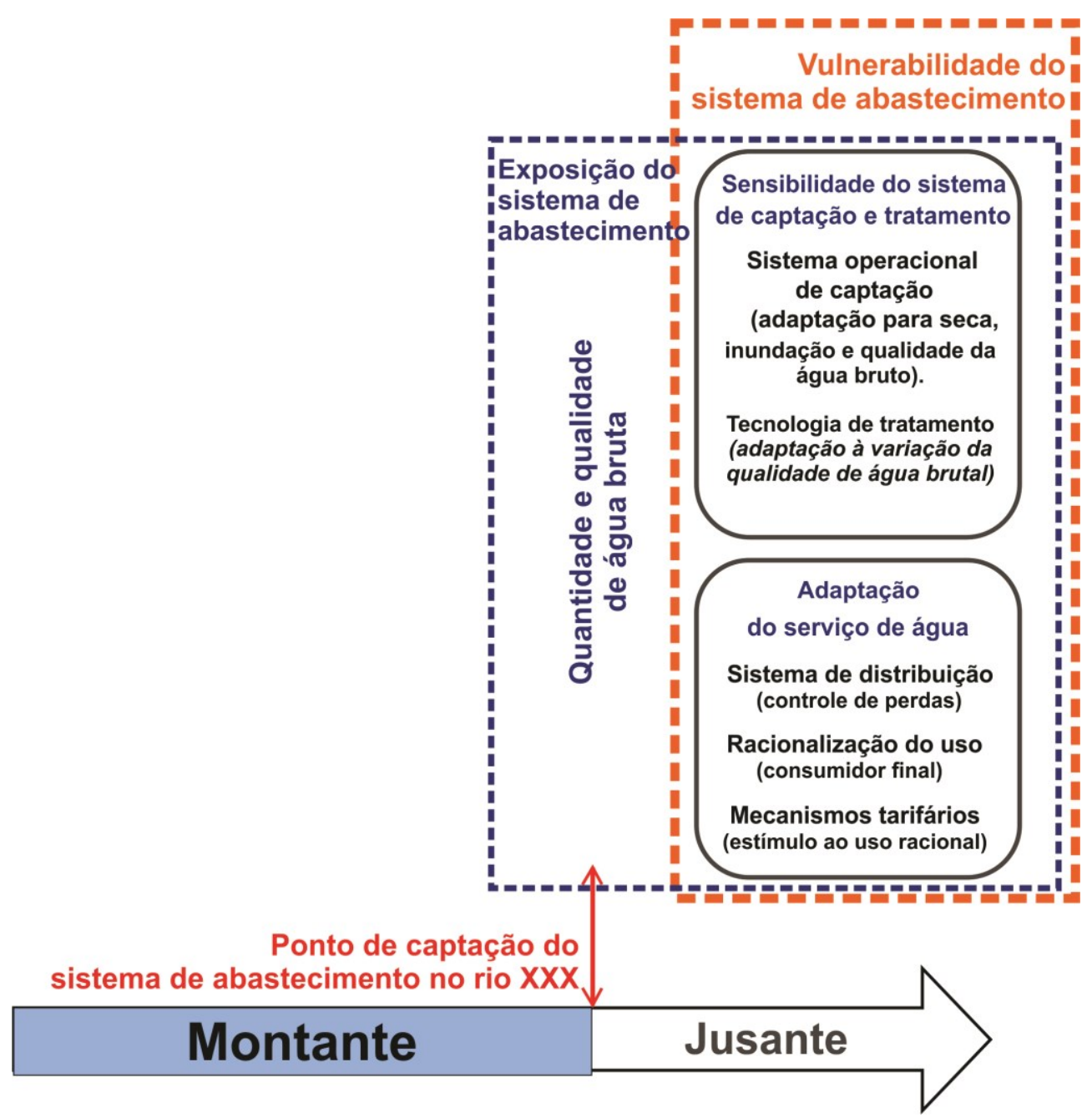

Para este trabalho, será efetuada uma avaliação qualitativa simplificada da vulnerabilidade do sistema de abastecimento, em particular:

- Subsistema de captação, face à disponibilidade de água em quantidade, em situações de normalidade hidrológica e de secas, e face à integridade da infraestrutura em situações de inundação;

- Subsistema de tratamento, face à qualidade de água no ponto de captação em situações de normalidade hidrológica, secas inundações e face à integridade da infraestrutura em situações de inundação.

Para cada uma dessas situações, será efetuada uma análise matricial combinando os três graus qualitativos atribuídos à exposição e à sensibilidade, resultando em nove medidas possíveis de vulnerabilidade. A vulnerabilidade resultante será correspondente à graduação corrente da literatura, que varia de baixa a muito alta (Figura 5). 
FIGURA 5 - Matriz de determinação da vulnerabilidade

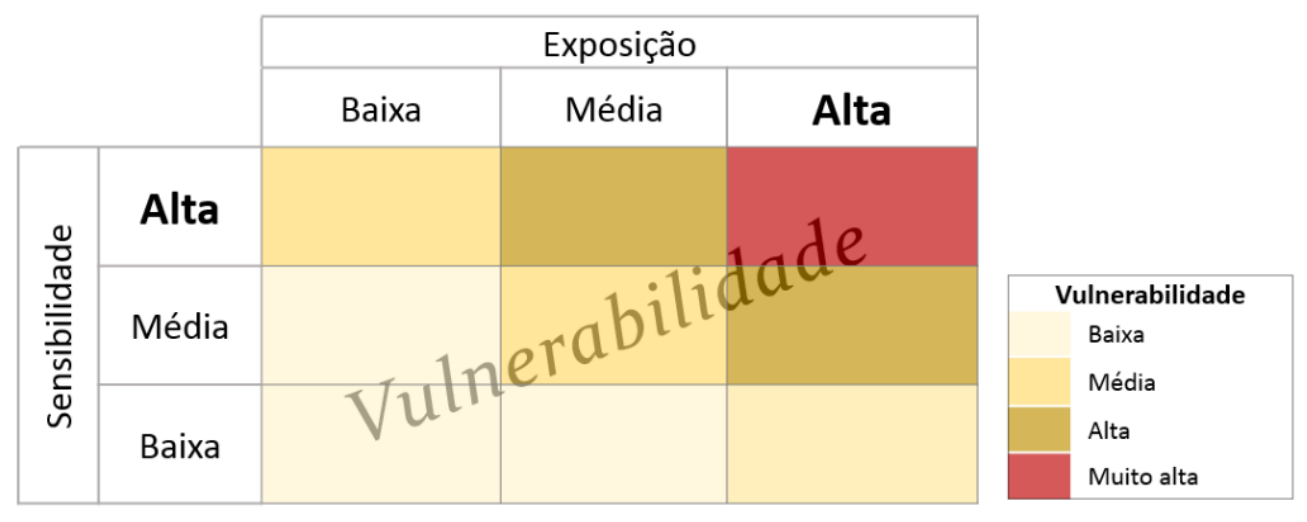

Embora seja uma avaliação simplificada, esta graduação é um bom indicador do nível de vulnerabilidade de um determinado sistema de abastecimento em relação à sua exposição na bacia hidrográfica, em termos de quantidade e qualidade de água bruta, combinada com as características intrínsecas dos seus componentes de captação e tratamento.

Quanto maior for a vulnerabilidade, maior é o risco para a segurança hídrica do abastecimento urbano em questão e maior será a necessidade de intervenção, no sistema de abastecimento e/ou na gestão da bacia hidrográfica. As possibilidades de intervenção variam bastante e devem ser definidas de acordo com as características específicas de cada caso.

Em suma, as análises segundo a metodologia aqui proposta, mesmo sendo uma mensuração qualitativa, constroem um panorama sistêmico acerca da situação de segurança hídrica de um determinado sistema urbano de abastecimento e, sobretudo, fornecem indicativos claros para os decisores políticos sobre quais devem ser as prioridades para as ações de gestão do risco, o que envolve a gestão ambiental do manancial-bacia hidrográfica e a gestão do sistema de abastecimento, visando aumentar a garantia de segurança hídrica. 


\section{CARACTERIZAÇÃO DO OBJETO DE ESTUDO}

O modelo analítico de segurança hídrica, apresentado no Capítulo 3, será aplicado ao estudo de caso do abastecimento da sede municipal de Porto nacional, Tocantins. O manancial de abastecimento da sede do Município é o Córrego São João, afluente de primeira ordem do rio Tocantins, que deságua hoje no Lago da Usina Hidrelétrica Luís Eduardo Magalhães.

A escolha deste estudo de caso deve-se, de um lado, à oportunidade de contribuir para o tema 'segurança hídrica' do abastecimento de municípios de pequeno porte, como Porto Nacional; em geral, o assunto é privilegiado para aglomerações e metrópoles. De outro lado, é uma oportunidade de trazer contribuições para este caso, trazendo uma nova perspectiva (de segurança hídrica do abastecimento urbano) para a gestão da bacia hidrográfica e para o município de Porto nacional, a partir de informações disponíveis.

Portanto, este capítulo apresentará os principais resultados da pesquisa bibliográfica relacionados ao objeto de estudo, a saber: a bacia hidrográfica do Córrego São João; e o sistema de abastecimento público da sede municipal de Porto Nacional, em particular os subsistemas de captação e tratamento, que interessam mais diretamente a este estudo.

\subsection{Bacia hidrográfica do Córrego São João}

De acordo com o plano Estadual de Recursos Hídricos, o estado do Tocantins é dividido em 17 áreas estratégicas de gestão (AEGS), sendo que a bacia hidrográfica do córrego São João está localizada na região central da Bacia Hidrográfica do Lago de Palmas da UHE Luís Eduardo Magalhães, e está localizado na região central da Bacia Hidrográfica Araguaia-Tocantins, na porção centro-sul do Estado do Tocantins, de acordo com a figura 6, a bacia do Lago de Palmas encontra-se entre duas AEG's: a de número 10 - Rio Manuel Alves em Natividade e a de número 11- Palmas (FAPTO, 2015). 
FIGURA 6 - Áreas estratégicas de gestão e localização da Bacia Hidrográfica do Lago de Palmas, no estado do Tocantins.

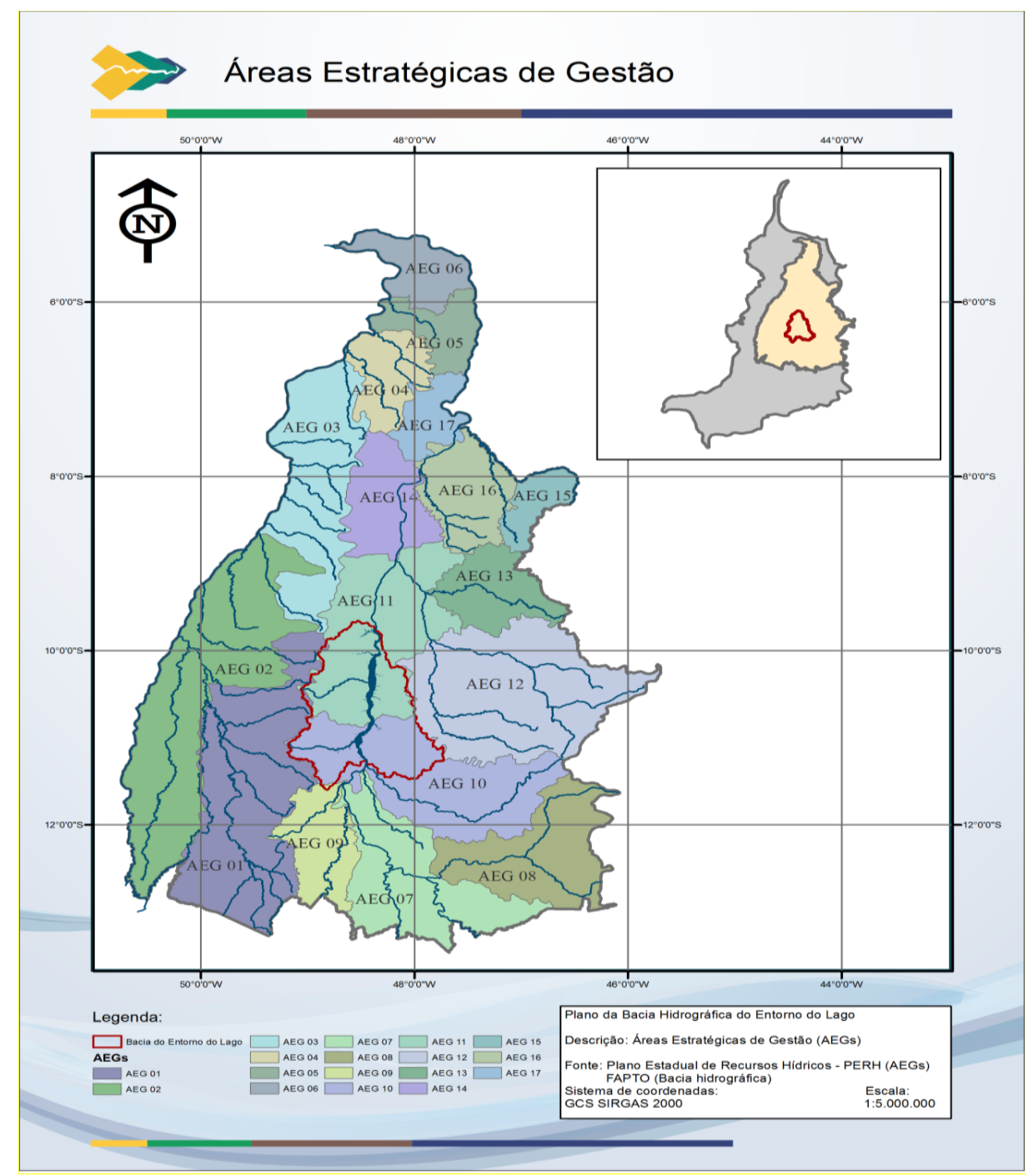

Fonte: FAPTO, 2015

A UHE Luís Eduardo Magalhães está localizada nas coordenadas geográficas $9^{\circ} 45^{\prime} 25,83^{\prime \prime}$ Sul $48^{\circ} 22^{\prime} 17,11^{\prime \prime}$ Oeste e a Bacia Hidrográfica delimitada pela área de drenagem dos cursos d'água que drenam diretamente para seu reservatório define a abrangência geográfica deste plano de bacia, então a Bacia do Entorno do Lago é formada por diversas sub-bacias, cada qual com sua rede de drenagem para uma única foz, a UHE Luís Eduardo Magalhães (FAPTO, 2015).

A Bacia do Córrego São João compreende dois municípios do Estado do Tocantins: Porto Nacional $(99,7 \%)$ e Monte do Carmo (0,3\%). A Bacia compreende inclusive a sede do Município de Porto Nacional apresentado na figura 7. 
FIGURA 7 - Mapa de localização da Bacia Hidrográfica do Córrego São João em Porto Nacional-TO

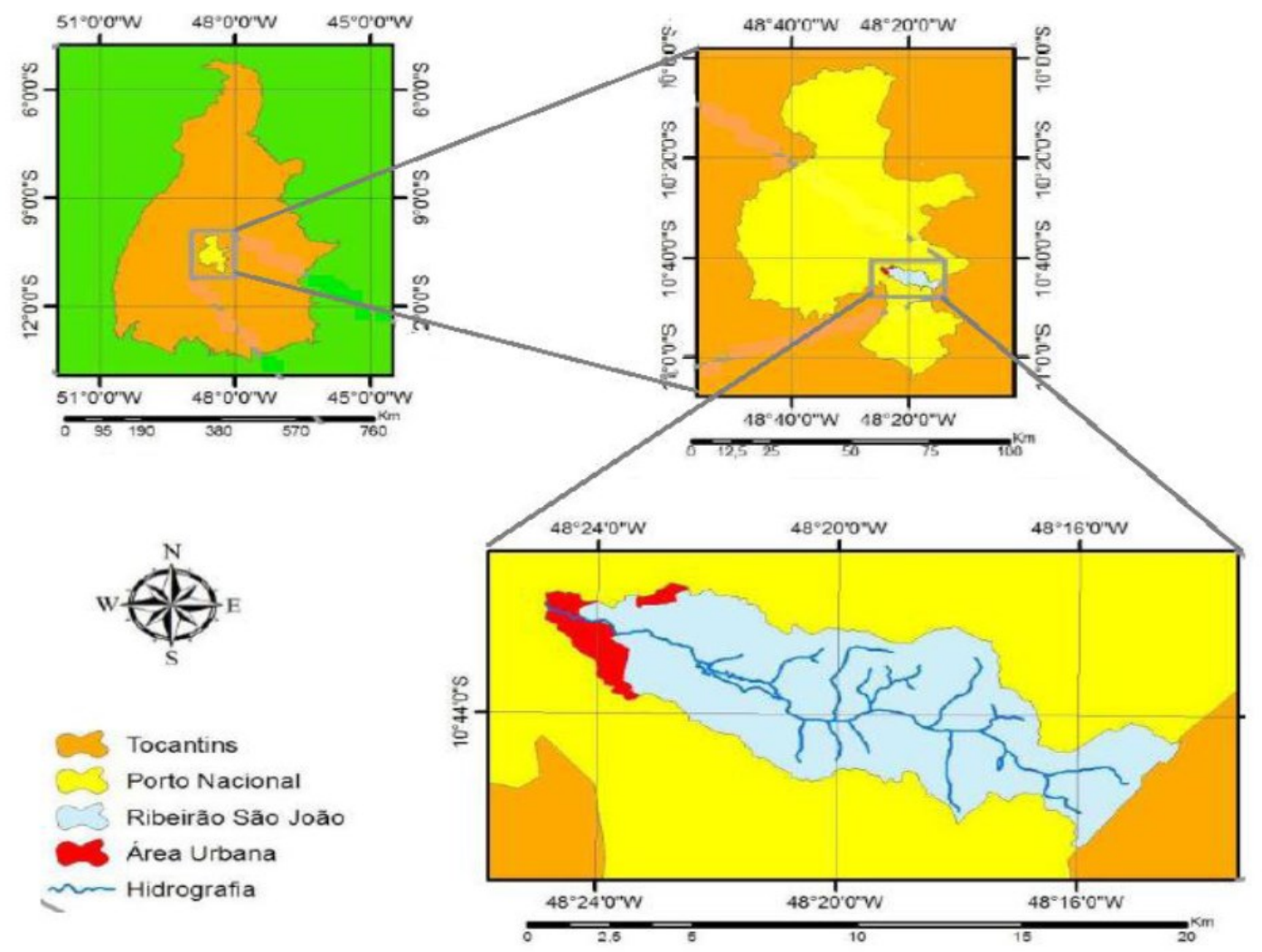

Fonte: Seplan (2008); Silva (2010)

O município de Porto Nacional é o quarto maior em população do estado do Tocantins, situa-se no centro geográfico do Estado, na mesorregião oriental, sendo que a cidade está à margem direita do Rio Tocantins. O município limita-se ao norte com os municípios de Palmas e Paraíso do Tocantins e ao sul com os municípios de Silvanópolis e Brejinho de Nazaré, a leste com os municípios de Monte do Carmo, Ipueiras e Brejinho de Nazaré, e a oeste com o Rio Tocantins e a BR-153, próxima a Fátima, Nova Rosalândia e Oliveira de Fátima. Possui altitude de 212 metros, referente ao reservatório da UHE acima do nível do mar, e uma superfície de $4.449,9 \mathrm{Km}^{2}$. A cidade dista $63 \mathrm{~km}$ ao sul de Palmas, capital do estado, e tem uma população estimada em 52.510 habitantes (IBGE, 2015).

No quesito socioeconômico, Porto Nacional é destacado pelo potencial agropecuário e ocupa a $4^{\mathrm{a}}$ posição do PIB dentre os 139 municípios do estado. $\mathrm{O}$ PIB per capita do município é de $\mathrm{R} \$ 13.652,27$, superior ao valor obtido do estado do Tocantins, sendo este de $\mathrm{R} \$ 12.462,00$. A participação do município para o PIB é relevante, representando $3,89 \%$ do PIB estadual, conforme apresentado na tabela 1 . 
TABELA 1 - Produto Interno Bruto - Município de Porto Nacional, 2010

\begin{tabular}{|l|l|}
\hline Agropecuária & $\mathrm{R} \$ 66.723,00$ \\
\hline Indústrias & $\mathrm{R} \$ 237.169,00$ \\
\hline Serviços & $\mathrm{R} \$ 298.501,00$ \\
\hline Impostos & $\mathrm{R} \$ 68.520,00$ \\
\hline Total & $\mathrm{R} \$ 670.913,00$ \\
\hline Tocantins TOTAL & $\mathrm{R} \$ 17.240 .000,00$ \\
\hline
\end{tabular}

Fonte: PMAE 2013

Cabe ressaltar que o setor de serviços prepondera no PIB de Porto Nacional, contribuindo com $44,49 \%$ dos valores monetários de todos os bens e serviços finais produzidos no município. Esse setor inclui atividades comerciais, pessoais e comunitárias, abrangendo a área de comercio, indústria, educação, administração pública , além de outras atividades indiretamente ligadas aos serviços (IBGE, 2010).

Quanto à densidade demográfica do município de Porto Nacional, conforme quadro 3, a partir do ano 2000 as estimativas populacionais indicam um aumento de concentração de habitantes km/2, que no fim da década foi de 11,04 hab/km², segundo os dados o último censo do IBGE (PMAE, 2013).

QUADRO 3 - Densidade demográfica Município de Porto Nacional

\begin{tabular}{|c|c|}
\hline ANO & Densidade (hab/km ${ }^{2}$ ) \\
\hline 2000 & 10,11 \\
\hline 2010 & 11,04 \\
\hline
\end{tabular}

Fonte: PMAE 2013

A bacia situa-se na região sudeste do município e tem como principal curso d'água o córrego São João, com vazão média anual de 1,556 m³/s, sendo 0,6555 m³ no período seco e $2,784 \mathrm{~m}^{3} / \mathrm{s}$ no período chuvoso (FAPTO, 2015). Suas nascentes encontram-se nas escarpas da Serra Manoel do Carmo, no município de Monte do Carmo, correndo no sentido SE/NO, desaguando no lago da Usina Hidrelétrica Luís Eduardo Magalhães (Rio Tocantins).

O principal uso do Córrego São João é para abastecimento público da sede municipal de Porto Nacional, cuja captação, figura 8, se situa no médio curso da Bacia, mas a montante da parte urbana. No entanto, outros usos se situam a 
montante do ponto de captação, tais como dessedentação de animais, pecuária, piscicultura e irrigações de atividades agrícolas. Importante ressaltar que, para o abastecimento humano, o Córrego São João é planejado também como o manancial responsável para atender a demanda futura em quantidade e qualidade de água, até o ano de 2042, segundo o Plano de Água e Esgoto do Município (PMAE,2013).

FIGURA 8 - Localização do ponto de captação da sede municipal de Porto Nacional

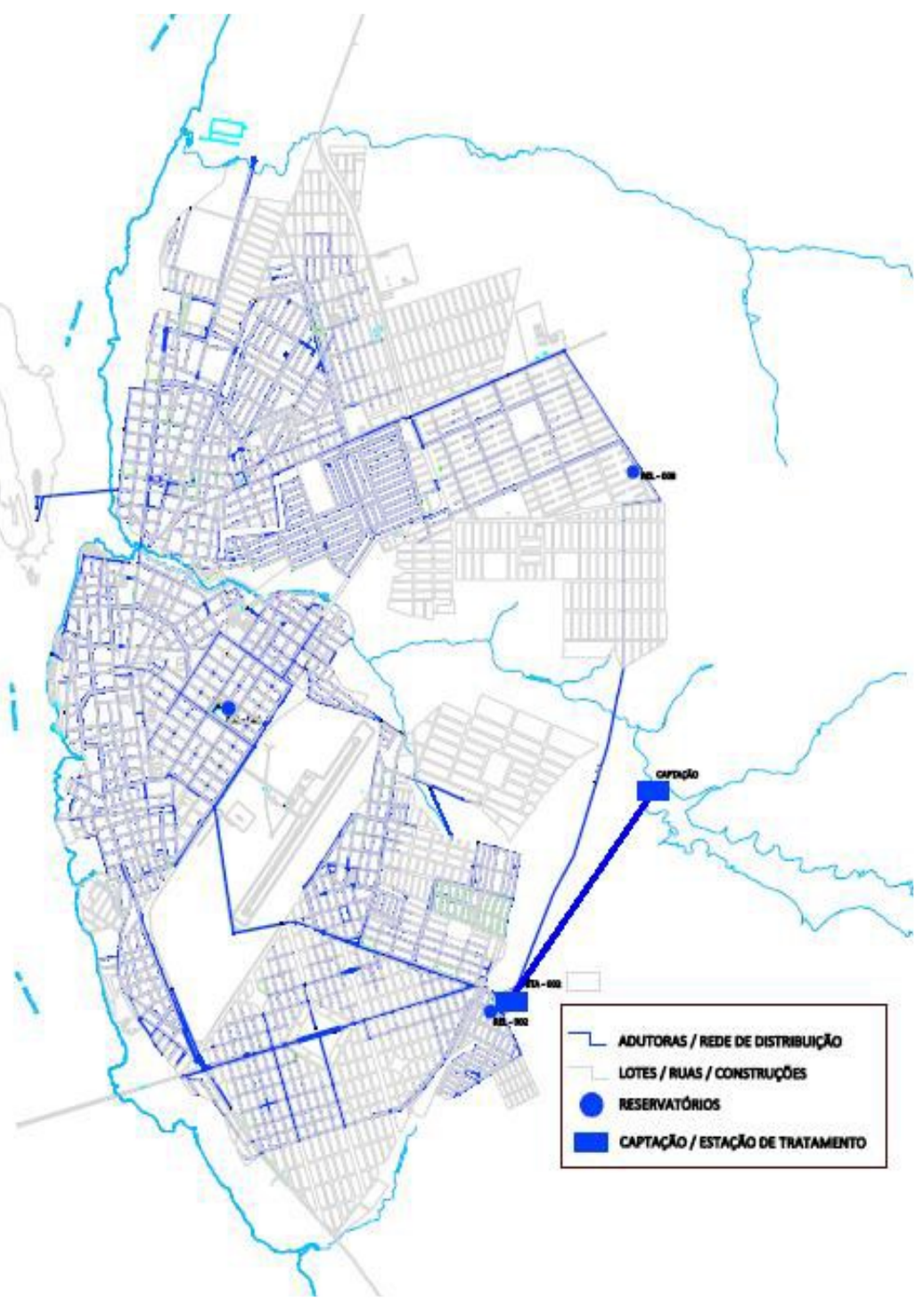

Fonte: PMAE 2013

A área de contribuição do reservatório é de $\mathbf{8 , 9} \mathbf{k m}^{2}$, onde se encontra o ponto de captação, que é a área da bacia do córrego São João com influência direta na água bruta captada e para abastecer a sede municipal de Porto Nacional.

A vazão do Córrego São João atualmente regularizada é de 168,93 L/s e a vazão de captação atual é de 119 L/s (ANA, 2010). Segundo o estudo do Plano 
Municipal de Água e Esgoto realizado em 2013, o índice de atendimento total de 99\% da população urbana correspondente a 45.206 habitantes em 2013 e com projeção de crescimento em 2042 para 191,93 L/s, para atendimento de 99\% ou 61.174 habitantes (PMAE, 2013).

\subsubsection{Características ambientais da Bacia do Córrego São João}

O clima da região de Porto Nacional é do tipo C2wA'a" (clima úmido subúmido com moderada deficiência hídrica no inverno), segundo o método de Thornthwaite (SEPLAN, 2012). Com característica tipicamente tropical, a média pluviométrica anual é de $1.667,9 \mathrm{~mm}$, sendo que a concentração das chuvas ocorre entre os meses de outubro a abril (estação chuvosa), correspondendo a cerca de $80 \%$ da pluviosidade anual, já o período seco se prolonga do mês de maio ao mês de setembro (RAMOS et al., 2009). Os meses mais quentes coincidem com o rigor da seca, em fins de agosto e setembro, sendo que a temperatura média anual é de 26,1 ${ }^{\circ} \mathrm{C}$ (RAMOS et al., 2009). A umidade relativa média anual está em aproximadamente $70 \%$, pois no período chuvoso os índices de umidade são superiores a $80 \%$ e no período seco inferiores a $50 \%$ (PMAE, 2013).

A vegetação predominante na região é o cerrado, cujas principais características são a grande presença de arbustos e de árvores esparsas, com galhos retorcidos e raízes profundas. Entre as diferentes fitofisionomias presentes na área, destacam-se também as matas galeria. $\mathrm{Na}$ área do município predominam os solos Cambissolos, Plintossolos, Gleissolos, Latossolos e Neossolos (PMAE, 2013).

O córrego São João, é uma bacia de $2^{\mathrm{a}}$ ordem, composto de sete canais de drenagem com extensão total de $35,52 \mathrm{~km}$ e extensão do canal principal de $18,36 \mathrm{~km}$, o divisor de águas da bacia representa um perímetro de 46,26km e amplitude altimétrica é de $321 \mathrm{~m}$ (GLORIA, 2011).

Os parâmetros utilizados e resultados obtidos por Gloria (2011) através do software SPRING, identificaram a variação morfométrica da rede de drenagem e do relevo, o valor encontrado da densidade de drenagem é de $0,40 \mathrm{~km} / \mathrm{km}^{2}$ indica a baixa densidade de drenagem da bacia, essa baixa densidade de drenagem está relacionada com um terreno mais poroso, o que facilita a infiltração da água no solo.

A densidade hidrográfica $(\mathrm{Dh})$ possibilita a verificação da quantidade de rios 
existentes por km2 em uma bacia hidrográfica, no quadro 4 são apresentados os parâmetros morfométricos da bacia do córrego São João (GLORIA, 2011)

QUADRO 4 - Parâmetros morfométricos para definição do padrão, da forma e das características do relevo na bacia do córrego São João.

\begin{tabular}{|l|c|c|}
\hline \multicolumn{1}{|c|}{ Parâmetro Morfométrico } & Índice (Unidade) & Bacia Córrego São João \\
\hline Índice de circularidade & $\mathrm{C}$ & 0,7 \\
\hline Relação de elongação & $\mathrm{Re}$ & 0,6 \\
\hline Textura da topografia & $\mathrm{Tt}$ & 0,60 \\
\hline Densidade de drenagem & $\mathrm{Dd}\left(\mathrm{km} / \mathrm{km}^{2}\right)$ & 0,40 \\
\hline Densidade hidrográfica & $\mathrm{Dh}\left(\mathrm{canais} / \mathrm{km}^{2}\right)$ & 0,08 \\
\hline Relação de relevo & $\mathrm{Rr}$ & 17,27 \\
\hline Coeficiente de manutenção & $\mathrm{Cm}\left(\mathrm{m}^{2} / \mathrm{m}\right)$ & 2.500 \\
\hline
\end{tabular}

Fonte: Gloria, R. B. (2011)

O trabalho de Gloria (2011) indicou uma baixa densidade hidrográfica, sendo a Bacia do córrego São João uma bacia alongada, sem maiores riscos de inundações provenientes de precipitações ${ }^{13}$.

Silva (2010) realizou um mapeamento geomorfológico da bacia em estudo o que proporcionou a confecção de mapas com variáveis geormorfológicas através do programa SPRING, entre eles a hipsometria, que refere-se à representação das elevações do terreno através do fatiamento do relevo em cotas altimétricas que visam demonstrar através de classes coloridas a sua distribuição espacial, conforme figura 9.

${ }^{13}$ Existem registros de inundações ocorridas no Jardim Querido à jusante, mas que outras causas podem estar envolvidas nesses episódios, como a ocupação em fundo de vale e problemas relacionados à rede urbana que escoa para o canal do São João. 
FIGURA 9 - Mapa de Hipsometria da bacia do córrego São João

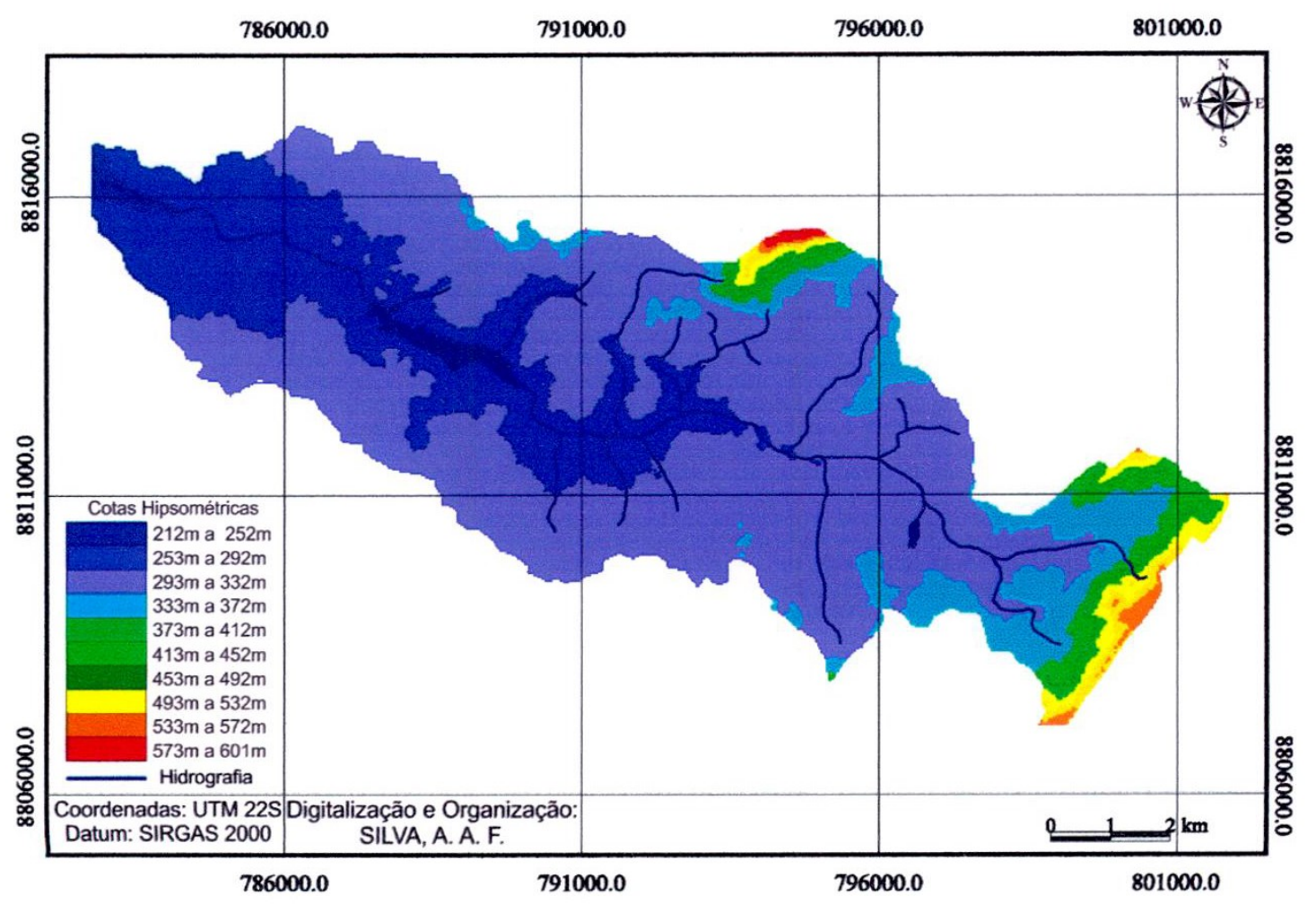

Fonte: Silva, A. A. F. (2010)

Silva (2010), utilizando a ferramenta do SPRING para a criação automática de perfil topográfico, calculou a divisão do curso hídrico principal da bacia em três patamares: alto curso (próximo à Serra do Manuel do Carmo até $2.500 \mathrm{~m}$ de comprimento), médio curso (de $2.500 \mathrm{~m}$ até o início do reservatório) e baixo curso (do inicio do reservatório até a foz), por meio da interpretação das principais linhas de quebra de relevo. Sendo que o reservatório para abastecimento público está localizado no médio curso da bacia (Figura 10).

FIGURA 10 - Perfil Topográfico do Córrego São João

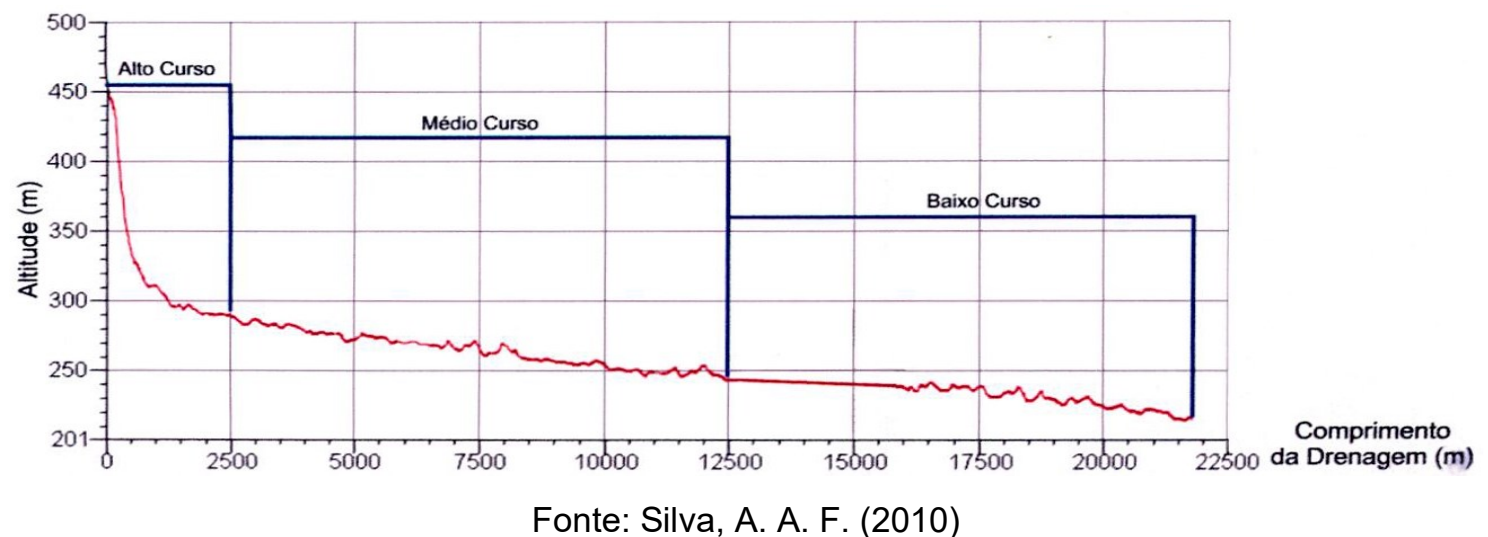


A declividade é a relação trigonométrica entre a diferença de altura entre dois pontos e a distância horizontal entre esses pontos, isto é, a inclinação da superfície do terreno em relação ao plano horizontal, ela é importante para determinar a angulação da vertente e predizer qual o seu tipo de modelado, com a ajuda da hipsometria local. A malha triangular gerada em graus decimais foi classificada em cinco classes de acordo com o sistema brasileiro de classificação de solos da Embrapa (1999), visualizado na Figura 11, a seguir (SILVA, 2010).

FIGURA 11 - Mapa de Declividade da Bacia do Córrego São João

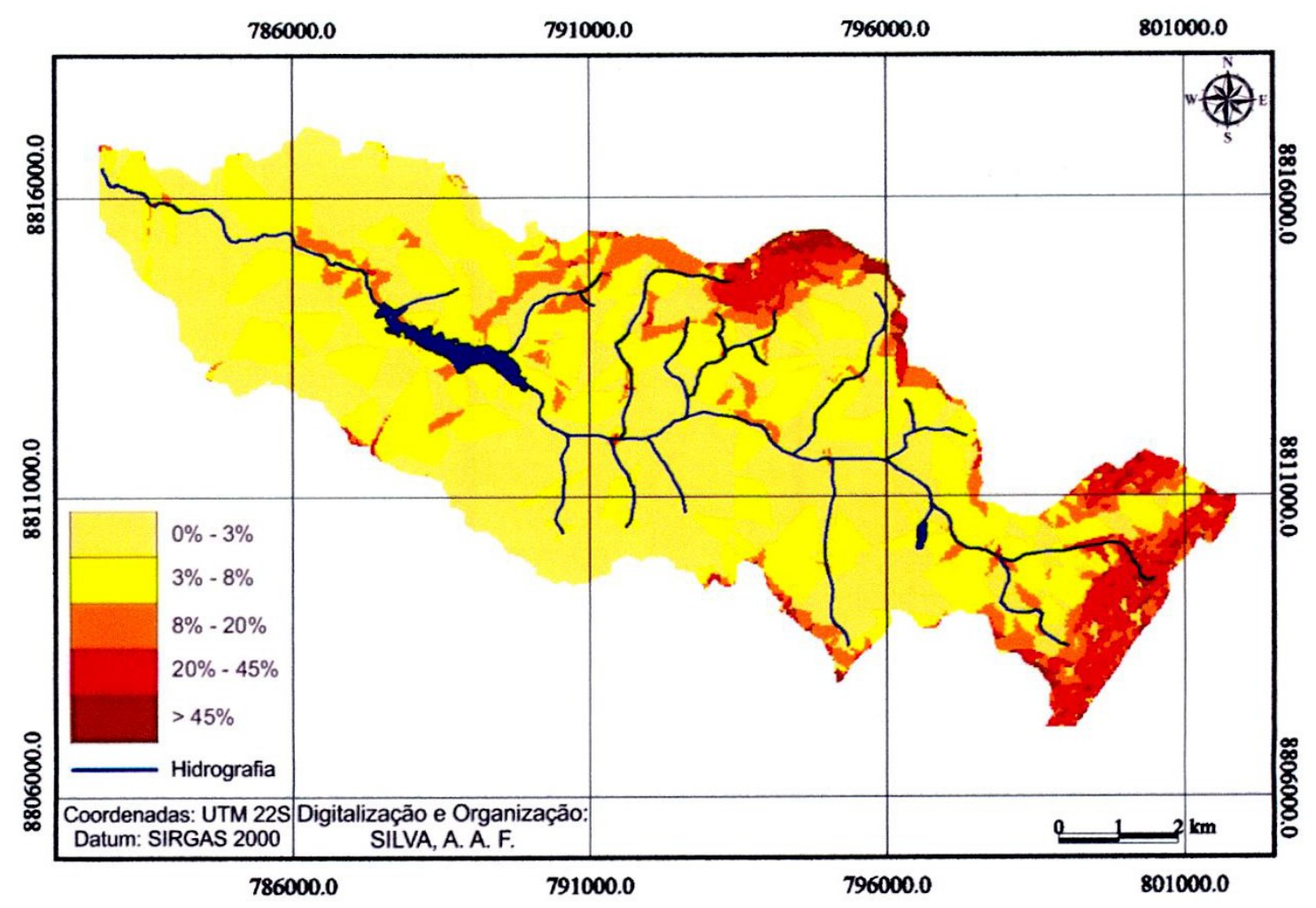

Fonte: Silva, A. A. F. (2010)

A bacia do Ribeirão São João possui $83 \%$ de sua área com declividade plana $(54 \%)$ ou suavemente ondulada $(29 \%)$. Isso justifica o intenso grau de entalhamento do vale, resultado das ações erosivas que desgastaram o relevo até chegar a esta taxa de declividade tão baixa, sendo que essa característica está relacionada também à localização regional da bacia à margem direita do rio Tocantins, situada na área compreendida pela unidade geomorfológica da Depressão do Tocantins (SILVA, 2010).

Na pesquisa de Silva (2010) é ressaltado que $72,85 \%$ de toda a área da bacia possui uma amplitude altimétrica de $80 \mathrm{~m}$, o relevo é plano e/ou suavemente 
ondulado, e mesmo com os divisores de águas sendo elevados em relação ao exutório (389 metros de diferença), aproximadamente $3 / 4$ da bacia apresenta uma área desgastada e erodida. Sendo que o morro São João é a única exceção, por se tratar de um morro isolado frente à paisagem local, que além de possuir as cotas altimétricas e declividades mais elevadas da bacia, serve consequentemente como limitador topográfico e nascente para cinco cursos d'água em suas vertentes.

\subsubsection{Uso e ocupação da terra da bacia no período de 1980 a 2016}

Segundo Cristo et al. (2010), a vegetação do cerrado na bacia hidrográfica do Córrego São João foi alterada pela expansão das atividades agropecuárias e agrícolas, sendo destacada a presença de várias represas no córrego São João e em seus afluentes, principalmente em seu alto curso, como meio de suprir a escassez hídrica do verão, sendo utilizadas para irrigação das culturas agrícolas e como bebedouros para o gado na atividade pecuária.

De acordo com Rocha (2015), a expansão agrícola em Porto Nacional intensificou-se a partir de 2003, quando se deu a modernização agrícola do município por meio da inserção do capital privado e a imigração de produtores especializados, substituindo gradativamente produtores locais e do Estado. A agregação desses agentes fomentou a sojicultura no município, sendo que no período entre 2003 e 2013 ocorreu um crescimento acima de $700 \%$ de áreas de produção de soja.

Segundo Bispo (2017) algumas regiões do cerrado que já passaram por processo de intensificação da produção de grãos, como a que se verifica no Tocantins, sofreram e ainda sofrem com as consequências desses processos, com os efeitos da degradação do meio ambiente.

No relatório fase $A$, do plano de bacias hidrográficas do lago de Palmas, Porto Nacional encontra-se no topo do ranking dos municípios de melhores solos com aptidão agrícola para plantio de culturas perenes, sendo que isso implica na demanda pela quantidade e qualidade de água (FAPTO, 2015).

O município de Porto Nacional destaca-se pela grande expansão na área plantada dentro do município, principalmente no que se refere à soja, que passou de 11.000 hectares em 2009 para 23.000 hectares em 2013. Um dos fatores indutores desse aumento na área plantada pode-se relacionar com a chegada da Granol, 
empresa esmagadora de soja e produtora de biodiesel, que iniciou suas operações no segundo semestre de 2015 (FAPTO, 2015).

Na sede municipal também se verifica um grande aumento de loteamentos novos que visam atender à demanda gerada por novos empregos gerados no município, alem do interesse especulativo que estimula o investimento em terra urbana (SOUZA, 2015). Empreendimentos no setor hoteleiro também confirmam o fluxo migratório temporário e permanente para Porto Nacional. Isso gera uma maior demanda por água e outros serviços de saneamento como tratamento de esgoto, coleta de lixo e drenagem urbana com pressão direta ou indireta sobre a bacia do córrego São João.

De acordo com Leite e Rosa (2011), por meio da figura com os mapas temáticos de uso e ocupação da terra na bacia hidrográfica do córrego São João (Figura 12), houve uma evolução da malha urbana, implantação de pastagens e de áreas agrícolas. Como consequência, a análise em diferentes datas (1980 a 2012), observou-se o predomínio de agricultura e pecuária desde a década de 80 , a classe temática denominada vegetação rala e/ou pastagem era responsável por $42,88 \%$ da área da bacia, em 1990 passou a responder por $64,33 \%$ ou 5713,88 ha.

Leite e Carvalho (2013), por meio de análise multitemporal de imagens orbitais, também verificaram um significativo aumento da ocupação urbana na bacia, passando de 4,2\% em 1980 para 15,4\% em 2012, o que chama a atenção por conta dos riscos à sua qualidade ambiental, conforme figura 12 . 
FIGURA 12 - Mapa de temático de uso e ocupação da terra na bacia hidrográfica do Córrego São João, no período de 1980 a 2012.

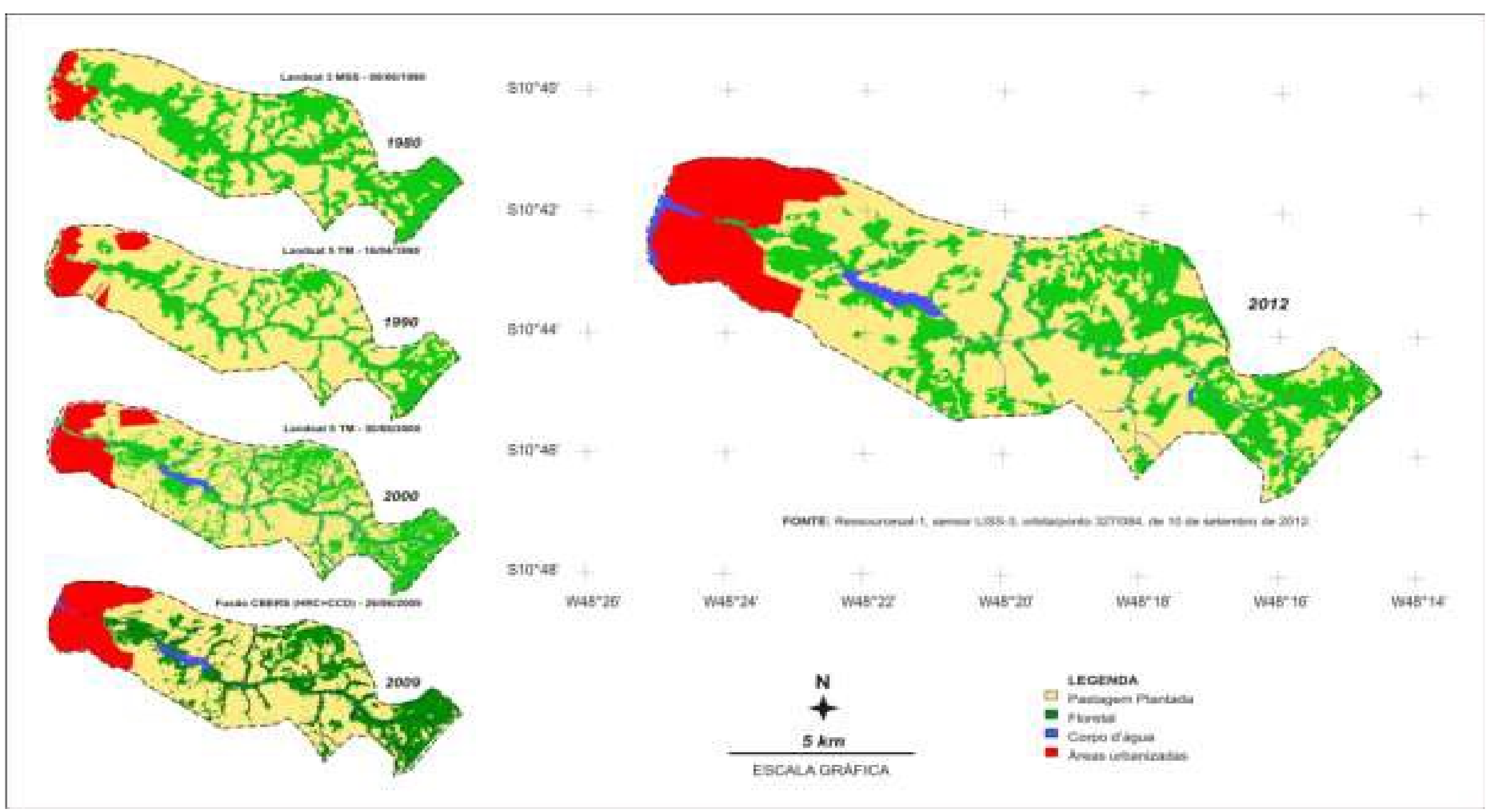

Fonte: (LEITE; ROSA 2011) 
Percebe-se uma mudança na demanda pelo uso da água, pois o diagnóstico do plano da bacia hidrográfica do entorno do lago (TOCANTINS, 2015) ressalta inciativas de investimentos para o município, destacando-se o agronegócio (expansão da produção de soja), que coloca o município de Porto Nacional em evidência, tornando-o um polo de crescimento econômico.

De acordo com Souza (2015), Porto Nacional encontra-se com novos loteamentos, sem que haja demanda efetiva por terrenos urbanizados, serviços de terraplanagem, aberturas de vias e obras de infraestrutura, essas ações estão sempre presentes e tendem a ser mais duradouras, em virtude da lenta ocupação dos vazios urbanos. Quando a etapa de implantação desses loteamentos (obras iniciais) coincide com o período chuvoso, é muito provável que os processos erosivos e o assoreamento de cursos d'água sejam potencializados, resultando em vultosos prejuízos ambientais.

\subsubsection{Outros estudos realizados na Bacia do Córrego São João}

A quantidade de estudos realizados e coletados sobre a bacia do córrego São João ratifica a preocupação de seus estudiosos em conservá-lo e a relevância do seu manancial para a manutenção do abastecimento humano da população urbana da sede de Porto Nacional.

Para pesquisar a bacia em estudo, foram feitas consultas nas seguintes fontes: acervo das bibliotecas físicas da UFT, campus Palmas e Porto Nacional; acervo digital das bibliotecas virtuais da Plataforma Sucupira, Domínio Público e da Biblioteca Digital de Teses e Dissertações onde várias universidades federais e estaduais disponibilizam seu acervo.

O quadro 5, a seguir, sistematiza os principais resultados da pesquisa realizada. Esse material sistematizado é de grande relevância para a caracterização da bacia e atualização dos dados mensurados em pesquisas anteriores, por exemplo, quanto ao uso e ocupação da terra e à qualidade da água. 
QUADRO 5 - Levantamento dos Estudos Realizados sobre a Bacia do Córrego São João

\begin{tabular}{|c|c|c|c|}
\hline $\begin{array}{l}\text { Instituição/ } \\
\text { Programa ou Fonte }\end{array}$ & Tipo & Título, Autor e ano & Principais Contribuições \\
\hline $\begin{array}{l}\text { UNITAU - Universidade de } \\
\text { Taubaté, Departamento de } \\
\text { Ciências Agrárias- Mestrado } \\
\text { em Ciências Ambientais }\end{array}$ & Dissertação & $\begin{array}{l}\text { Qualidade da água da bacia hidrográfica } \\
\text { do ribeirão são João na região centro } \\
\text { norte do Brasil no município de Porto } \\
\text { Nacional - Tocantins (BALDUINO, A. R., } \\
\text { 2013) }\end{array}$ & $\begin{array}{l}\text { As águas do ribeirão São João atenderam aos } \\
\text { padrões de qualidade determinados pela resolução } \\
357 / 05 \text { do CONAMA. } \\
\text { Identificados processos de degradação ambiental à } \\
\text { montante da captação de água. }\end{array}$ \\
\hline $\begin{array}{l}\text { GEOAMBIENTE On-Line } \\
\text { ISSN 1679-9860 } \\
\text { Revista Eletrônica do Curso } \\
\text { de Geografia n } 20 \text { Jan-Jun } \\
2013 \text { - Campus Jataí - UFG }\end{array}$ & Artigo & $\begin{array}{l}\text { Mapeamento do uso e cobertura da } \\
\text { terra na bacia hidrográfica do ribeirão } \\
\text { São João, Porto Nacional, Tocantins } \\
\text { (LEITE, E. F.; Carvalho, E. M. 2013) }\end{array}$ & $\begin{array}{l}\text { Utilização do software Spring/INPE para a detecção } \\
\text { temporal e espacial do uso e ocupação da Terra na } \\
\text { bacia hidrográfica do ribeirão São João; } \\
\text { Evolução da malha urbana e implantação de } \\
\text { pastagens; } \\
\text { Supressão e fragmentação da vegetação. }\end{array}$ \\
\hline $\begin{array}{l}\text { Anais XV Simpósio } \\
\text { Brasileiro de Sensoriamento } \\
\text { Remoto - SBSR Curitiba, } \\
\text { PR, Maio 2011, INPE } \\
\text { p.6365-6371 }\end{array}$ & Artigo & $\begin{array}{l}\text { Uso e ocupação da Terra na Bacia } \\
\text { Hidrográfica do Ribeirão São João, } \\
\text { Porto Nacional- TO: uma análise } \\
\text { espaço-temporal (LEITE, E. F.; ROSA, } \\
\text { R. 2011) }\end{array}$ & $\begin{array}{l}\text { Mapa da expansão urbana no período de } 1980 \text { a } \\
2010 \text { na bacia do ribeirão São João. } \\
\text { Identificação de supressão da vegetação. }\end{array}$ \\
\hline $\begin{array}{l}\text { GEOAMBIENTE On-Line } \\
\text { ISSN 1679-9860 } \\
\text { Revista Eletrônica do Curso } \\
\text { de Geografia n } 14 \text { Jan-Jun } \\
2010 \text { - Campus Jataí UFG }\end{array}$ & Artigo & $\begin{array}{l}\text { Diagnóstico preliminar de impactos } \\
\text { ambientais no trecho urbano do córrego } \\
\text { São João em Porto Nacional, TO } \\
\text { (ARAUJO, E. S. et al 2014) }\end{array}$ & $\begin{array}{l}\text { Diagnóstico visual da atividade antrópica no trecho } \\
\text { urbano do córrego São João (remoção de matas } \\
\text { ciliares, erosão, assoreamento, aporte de esgoto). }\end{array}$ \\
\hline
\end{tabular}




\begin{tabular}{|c|c|c|c|}
\hline $\begin{array}{c}\text { Instituição/ } \\
\text { Programa ou Fonte }\end{array}$ & Tipo & Título, Autor e ano & Principais Contribuições \\
\hline $\begin{array}{l}\text { Revista Eletrônica em } \\
\text { Gestão, Educação re } \\
\text { Tecnologia r Ambiental } \\
\text { REGET/UFSM e-ISSN } 2236 \\
1170-\text { V.18 Dez } 2014\end{array}$ & Artigo & $\begin{array}{l}\text { Meio ambiente na concepção de } \\
\text { usuários do rio Tocantins e do ribeirão } \\
\text { São João no município de Porto } \\
\text { Nacional - TO (CARVALHO, A. P.; } \\
\text { PAULA, M. A. N. R. 2014) }\end{array}$ & $\begin{array}{l}\text { Percepção ambiental que desfavorece a construção } \\
\text { de valores reflexivos na formação de sujeitos críticos. } \\
\text { Conhecimento restrito sobre responsabilidade } \\
\text { ambiental. }\end{array}$ \\
\hline $\begin{array}{l}\text { XXIX } r \text { Congresso } \\
\text { Interamericano } r \text { de } \\
\text { Engenharia Sanitária e } \\
\text { Ambiental, 2004, San Juan. }\end{array}$ & Artigo & $\begin{array}{l}\text { Avaliação da influência do córrego São } \\
\text { João no aporte de contaminação fecal } \\
\text { no reservatório da UHE Luís Eduardo } \\
\text { Magalhães, Tocantins-Brasil, e a a } \\
\text { respectiva influência na balneabilidade } \\
\text { das praias locais (NAVAL L.P. et al) }\end{array}$ & $\begin{array}{l}\text { Presença de coliformes fecais na foz do ribeirão São } \\
\text { João; Identificações de ligações de esgoto } \\
\text { clandestinas a jusante no trecho urbano; Influência } \\
\text { negativa na qualidade da água do reservatório da } \\
\text { UHE Luís E. Magalhães para a balneabilidade da } \\
\text { Praia de Porto Real. }\end{array}$ \\
\hline $\begin{array}{l}\text { Holos Enviroment, v. } 2 \text { n.2, } \\
2002 \text {, p. 174-184 ISSN } \\
1519-8421 . \text { Unesp }\end{array}$ & Artigo & $\begin{array}{l}\text { BORGES, K. P.; BERTOLIN, A.O. } \\
\text { Avaliação Microbiológica da } \\
\text { qualidade da água do Córrego São } \\
\text { João, Porto Nacional - To, Brasil. }\end{array}$ & $\begin{array}{l}\text { Avaliação Microbiológica do Córrego São João no } \\
\text { período de } 1996 \text { a } 1998 \text {. Conclusão de água } \\
\text { inapropriada para consumo humano sem prévia } \\
\text { desinfecção e para irrigação de hortas. }\end{array}$ \\
\hline 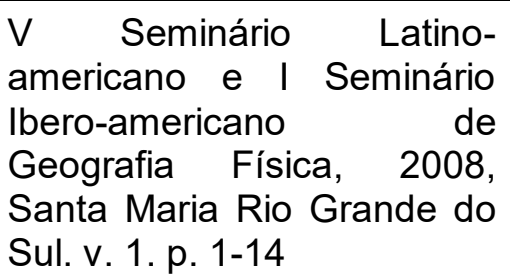 & Artigo & $\begin{array}{l}\text { Analise do uso e ocupação da bacia } \\
\text { hidrográfica do córrego São João } \\
\text { através de técnicas do sensoriamento } \\
\text { remoto, Porto Nacional - Tocantins - } \\
\text { Brasil. (CRISTO, S. S. V.; SILVA-NETO. } \\
\text { A. A. 2010) }\end{array}$ & $\begin{array}{l}\text { Confeç̧ão do mapa de uso do solo nas seguintes } \\
\text { classes: Urbanização, Solo Exposto, Agropecuária, } \\
\text { Drenagem e Formações Florestais. Identificação de } \\
\text { intensa ocupação da área com agricultura, pecuária } \\
\text { e urbanização, como principais fatores de } \\
\text { degradação ambiental. }\end{array}$ \\
\hline FAPTO/UFT & $\begin{array}{l}\text { Relatório do } \\
\text { Plano da } \\
\text { Bacia do } \\
\text { Lago }\end{array}$ & 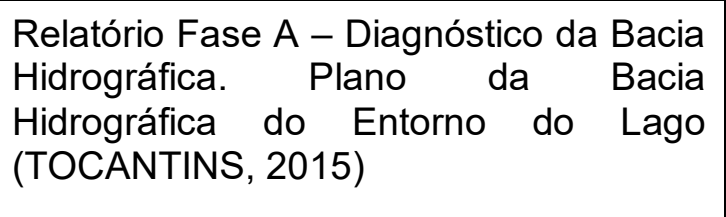 & $\begin{array}{l}\text { Descrição das } 16 \text { sub-bacias que são afluentes da } \\
\text { bacia do entorno do lago. } \\
\text { Vazão média do Córrego São João. } \\
\text { Área de aptidão agrícola de Porto Nacional. }\end{array}$ \\
\hline $\begin{array}{lr}\text { UFT - Universidade Federal } \\
\text { do } & \text { Tocantins, } \\
\text { Especialização } & \text { em }\end{array}$ & Monografia & $\begin{array}{l}\text { Análise do uso da terra na sub-bacia } \\
\text { hidrográfica do córrego São João, } \\
\text { município de Porto Nacional - TO. }\end{array}$ & $\begin{array}{l}\text { O córrego São João recebe as águas de pequenos } \\
\text { afluentes em sua grande maioria intermitentes. } \\
\text { Identificação dos principais afluentes, sendo da }\end{array}$ \\
\hline
\end{tabular}




\begin{tabular}{|c|c|c|c|}
\hline $\begin{array}{c}\text { Instituição/ } \\
\text { Programa ou Fonte }\end{array}$ & Tipo & Título, Autor e ano & Principais Contribuições \\
\hline Geografia & & (SILVA-NETO, A. A., 2006) & $\begin{array}{l}\text { margem direita os córregos: Cachoeirinha, Cangalha, } \\
\text { Afatí, Brejinho; e da sua margem esquerda os } \\
\text { córregos: Fazendinha, Cabeceira do Meio, Jacozinho } \\
\text { e Brejo Roldão. }\end{array}$ \\
\hline $\begin{array}{l}\text { UFT - Universidade Federal } \\
\text { do Tocantins, Bacharelado } \\
\text { em Geografia }\end{array}$ & Monografia & $\begin{array}{l}\text { Geoprocessamento Aplicado a Analise e } \\
\text { Mapeamento Geomorfológico da Bacia } \\
\text { Hidrográfica do Ribeirão São João. } \\
\text { Porto Nacional - TO (SILVA, A. A. F., } \\
\text { 2010) }\end{array}$ & $\begin{array}{l}\text { Mapeamento geomorfológico e atualização da rede } \\
\text { de drenagem. } \\
\text { Hipsometria - Amplitude altimétrica da bacia em } 81 \% \\
\text { da bacia é de } 79 \mathrm{~m} \text { ( } 212 \text { até } 332 \mathrm{~m}) \text {; } \\
\text { Declividade }-83 \% \text { declividade plana e } 29 \% \\
\text { levemente ondulada; } 3 / 4 \text { da bacia encontra-se } \\
\text { erodida e desgastada. }\end{array}$ \\
\hline $\begin{array}{l}\text { UFT - Universidade Federal } \\
\text { do Tocantins, Bacharelado } \\
\text { em Geografia }\end{array}$ & Monografia & 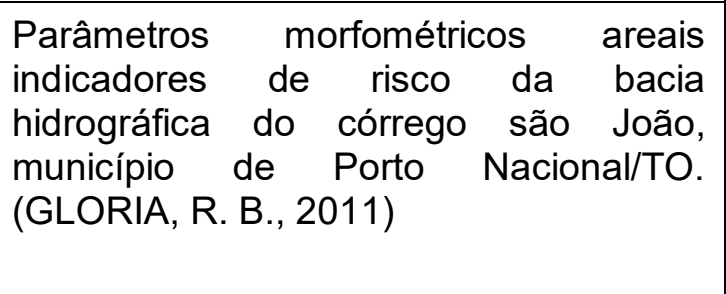 & $\begin{array}{l}\text { Mensuração dos canais existentes da bacia, } \\
\text { comprimento total dos canais e potencial hídrico da } \\
\text { bacia. } \\
\text { Parâmetros (área da bacia; formato; distancias e } \\
\text { relações de relevo) calculados pelo software } \\
\text { SPRING. }\end{array}$ \\
\hline $\begin{array}{l}\text { UFT - Universidade Federal } \\
\text { do Tocantins, Bacharelado } \\
\text { em Biologia }\end{array}$ & Monografia & 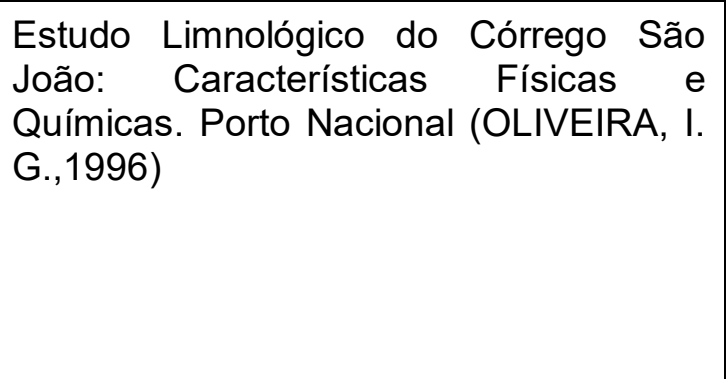 & $\begin{array}{l}\text { A grande variabilidade espacial ou ambiental do } \\
\text { córrego São João deve-se a multiplicidade de usos } \\
\text { de sua bacia (abastecimento, agricultura e pecuária } \\
\text { de subsistência, indústria cerâmica, assentamento } \\
\text { humano, recreação e lazer). } \\
\text { Área de captação comprometida em sua proximidade } \\
\text { com a área urbana recebendo resíduos domésticos } \\
\text { (esgoto e detergente) }\end{array}$ \\
\hline
\end{tabular}




\begin{tabular}{|l|l|l|l|}
\hline \multicolumn{1}{|c|}{$\begin{array}{c}\text { Instituição/ } \\
\text { Programa ou Fonte }\end{array}$} & Tipo & \multicolumn{1}{|c|}{ Título, Autor e ano } & \multicolumn{1}{c|}{ Principais Contribuições } \\
\hline $\begin{array}{l}\text { UFT - Universidade Federal } \\
\text { do Tocantins, Bacharelado } \\
\text { em Biologia }\end{array}$ & Monografia & $\begin{array}{l}\text { Levantamento florístico e } \\
\text { fitossociológico em mata de galeria da } \\
\text { sub-bacia do ribeirão São João, Porto } \\
\text { Nacional, TO. (BORGES, G.C., 2007) }\end{array}$ & $\begin{array}{l}\text { Diagnóstico a composição florística da mata de } \\
\text { galeria e estrutura fitossociológica das espécies } \\
\text { lenhosas em uma área na sub-bacia do ribeirão são } \\
\text { João, buscando o fornecimento de subsídios às } \\
\text { ações de recuperação de áreas degradadas ao longo } \\
\text { da sub-bacia. }\end{array}$ \\
\hline $\begin{array}{l}\text { UFT - Universidade Federal } \\
\text { do Tocantins, Licenciatura } \\
\text { em Biologia }\end{array}$ & Monografia & $\begin{array}{l}\text { A fotografia como recurso metodológico } \\
\text { em ações de Educação Ambiental no no } \\
\text { Ribeirão São João, Porto Nacional/TO. } \\
\text { (RIBEIRO, L. S., 2014) }\end{array}$ & $\begin{array}{l}\text { Margens da foz do ribeirão na área urbana com } \\
\text { desmatamento das matas ciliares e presença de } \\
\text { resíduos sólidos. }\end{array}$ \\
\hline
\end{tabular}


Após levantamento das pesquisas, relatórios, artigos e trabalhos acadêmicos registrados ratifica-se a importância da qualidade ambiental da bacia hidrográfica do córrego São João, tendo em vista que a mesma é estudada há mais de duas décadas e que a cidade de Porto Nacional é dependente de seus recursos hídricos.

\subsection{Sistema de abastecimento urbano de Porto Nacional}

Após a contextualização mais ampla da bacia hidrográfica do Córrego São João, apresentaremos a seguir os sistemas que compõem o abastecimento urbano da sede municipal de Porto Nacional. O conhecimento amplo de todo o sistema de abastecimento público da sede municipal de Porto Nacional, permite situar a importância do estudo de caso na bacia hidrográfica do Córrego São João.

O município de Porto Nacional, como os demais municípios do norte do estado de Goiás, era abastecido pela Companhia de Saneamento de Goiás. Após a criação do Estado do Tocantins, e o consequente desmembramento da Companhia de Saneamento de Goiás - SANEAGO, foi criada a SANEATINS - Companhia de Saneamento do Tocantins, de domínio do estado. Porém, com o objetivo de desenvolver os serviços de saneamento no novo Estado, em 1998, o Governo do Tocantins buscou uma parceria societária estratégica com a iniciativa privada, tornando a SANEATINS uma empresa com gestão privada. Desde outubro de 2011, tendo como controladora a Foz do Brasil (empresa de engenharia ambiental da Organização Odebrecht), a Foz/SANEATINS tem como desafio tornar o Tocantins o primeiro estado do país a ter os serviços de água e esgoto universalizados. (PMAE, 2013).

Em outubro de 1999 a Prefeitura Municipal de Porto Nacional e a Companhia de Saneamento do Tocantins (SANEATINS) firmaram Contrato de Concessão $n^{\circ} 157 / 99$, com prazo de 30 (trinta) anos e cujo objeto principal é a exploração em regime de exclusividade, dos serviços públicos de água e esgoto no Município. Em 2017 ocorreu uma aquisição recente da Odebrecht Ambiental pelo fundo de investimento da Brookfield, empresa canadense e mudança para a BRK Ambiental, como prestadora de serviços de abastecimento público de Porto Nacional.

Segundo o Plano Municipal de Água e Esgoto do ano de 2013, Porto Nacional possui $99,0 \%$ da população urbana da Sede Municipal atendida com abastecimento 
de água tratada, e os padrões de qualidade no atendimento são garantidos. Já o atendimento com esgoto corresponde a $61 \%$ da população urbana atendida na Sede Municipal e todo esgoto coletado é tratado, sendo este devolvido ao manancial hídrico no Córrego Franscisquinha, visando melhorar a situação dos cursos d'água locais. (PMAE, 2013).

A concessionária responsável pelo abastecimento público do município, possui estação de tratamento de água, denominada ETA 02, responsável pelo atendimento de aproximadamente 45.206 habitantes, possui uma vazão de produção de até $175 \mathrm{~L} / \mathrm{s}$, com uma demanda de consumo entre 10 a $12 \mathrm{mil} \mathrm{m} 3 / \mathrm{dia}$. Em janeiro de 2016, o faturamento contabilizou 15.929 ligações ativas na sede de Porto Nacional, segundo informações da referida empresa.

Todavia, nos últimos anos, a Prefeitura de Porto Nacional tem autorizado o parcelamento do solo, via loteamentos, sem a presença de rede de esgotos, o que deverá contribuir para a redução do percentual de população urbana atendida com esse tipo de infraestrutura. Por outro lado, a instalação futura da rede de esgotos nesses loteamentos deverá ocorrer mediante transferência desse ônus dos empreendedores para o poder público e a população.

\subsubsection{Captação e tratamento}

A captação de água bruta é superficial, no Córrego São João, utilizando-se do seu represamento (Figura 13) e bombeamento da água bruta para a Estação de Tratamento de Água ETA - 02. O lago possui $8,9 \mathrm{~km}^{2}$ de área inundada e tem capacidade de fornecimento de água para as demandas atuais e futuras da cidade (PMAE, 2013).

FIGURA 13 - Barragem no Córrego São João

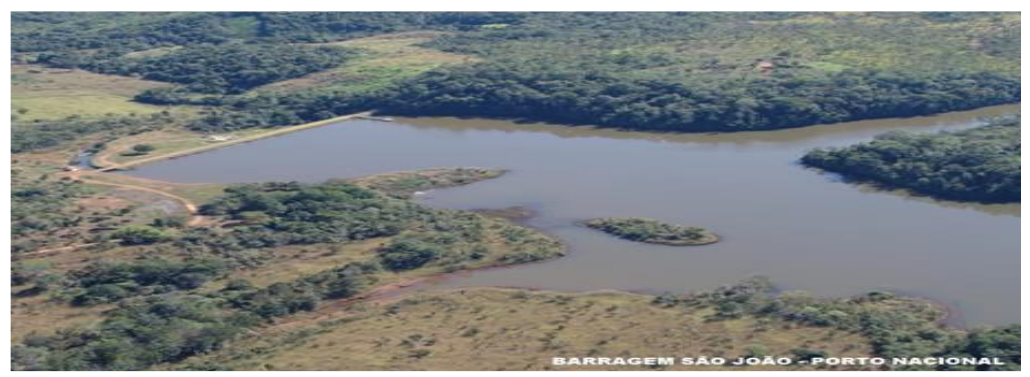

Foto: Acervo Foz/Saneatins 
Segundo o PMAE (2013), a estação elevatória e a adutora de água bruta que interliga a captação superficial no Córrego São João à estação de tratamento de água - ETA 001 tem as seguintes características:

- Elevatória de Água Bruta - EEAB 001;

- Localização: Córrego São João

- Modelo (1Conj. Moto - Bomba + 1 reserva) - Eberle / BCT Worthington 8LN18A

- Potência: 175 cv;

- Sub-estação: 150 KVa;

- Vazão: 170 L/s.

- Adutora de Água Bruta - AAB 001:

- Cota saída: 241,4

- Cota chegada: 284,9

- Diâmetro/material: DN 500 mm (FoFo); e

- Comprimento: 2035 metros

FIGURA 14 - Ponto de captação superficial na represa - Fazenda Jaiara

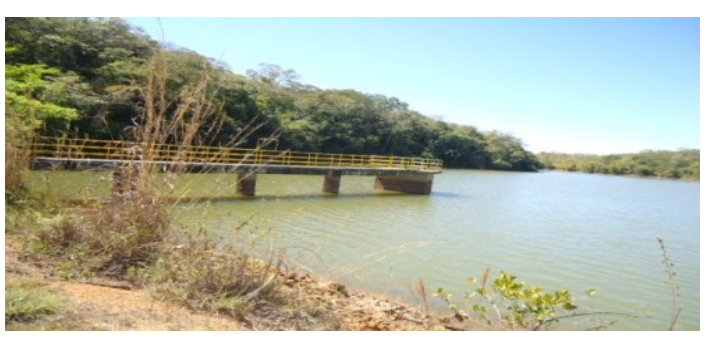

Foto: Bernardeli, M. (outubro 2015)

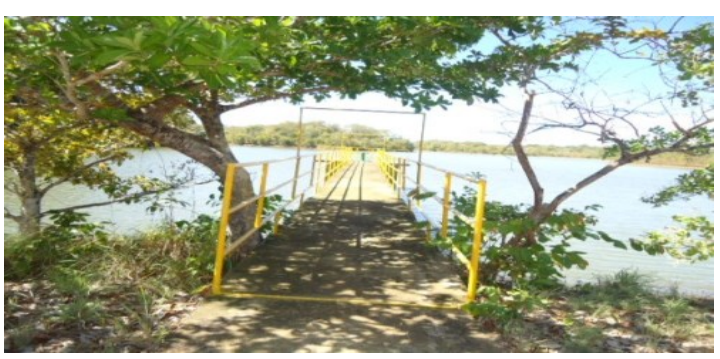

Foto: Bernardeli, M. (outubro 2015)

No quadro 6, pode-se observar a vazão demandada para o abastecimento humano relacionando a área por população.

QUADRO 6 - Vazões demandadas estimadas para Abastecimento Humano por Subbacias

\begin{tabular}{|c|c|c|c|}
\hline Sub-bacia & Area $\mathbf{( k m}^{\mathbf{2}}$ ) & População (2015) & Vazão (L/s) \\
\hline Córrego São João & 81,899 & 44.082 & 122,45 \\
\hline
\end{tabular}

Fonte: FAPTO (2015) 


\subsubsection{Estação de tratamento de água}

Em Porto Nacional, a água é captada através da barragem de acumulação do córrego São João o tratamento é do tipo convencional e passa pelos seguintes processos de tratamento: captação, adução, coagulação, dupla filtração, desinfecção, fluoretação, reservação e distribuição. A estação de tratamento situa-se na Rua Contorno, s/n, Parque Eldorado, apresentado na figura 15.

A água coagulada então passa pelo processo de dupla filtração (uma filtração ascendente e uma descendente), sendo que na ETA velha, os filtros ascendentes e os descendentes são de areia, e na ETA nova os filtros ascendentes são de pedregulho e os descendentes são de areia, totalizando no sistema 20 filtros (PMAE, 2013).

FIGURA 15 - Estação de Tratamento de Água de Porto Nacional - ETA 02

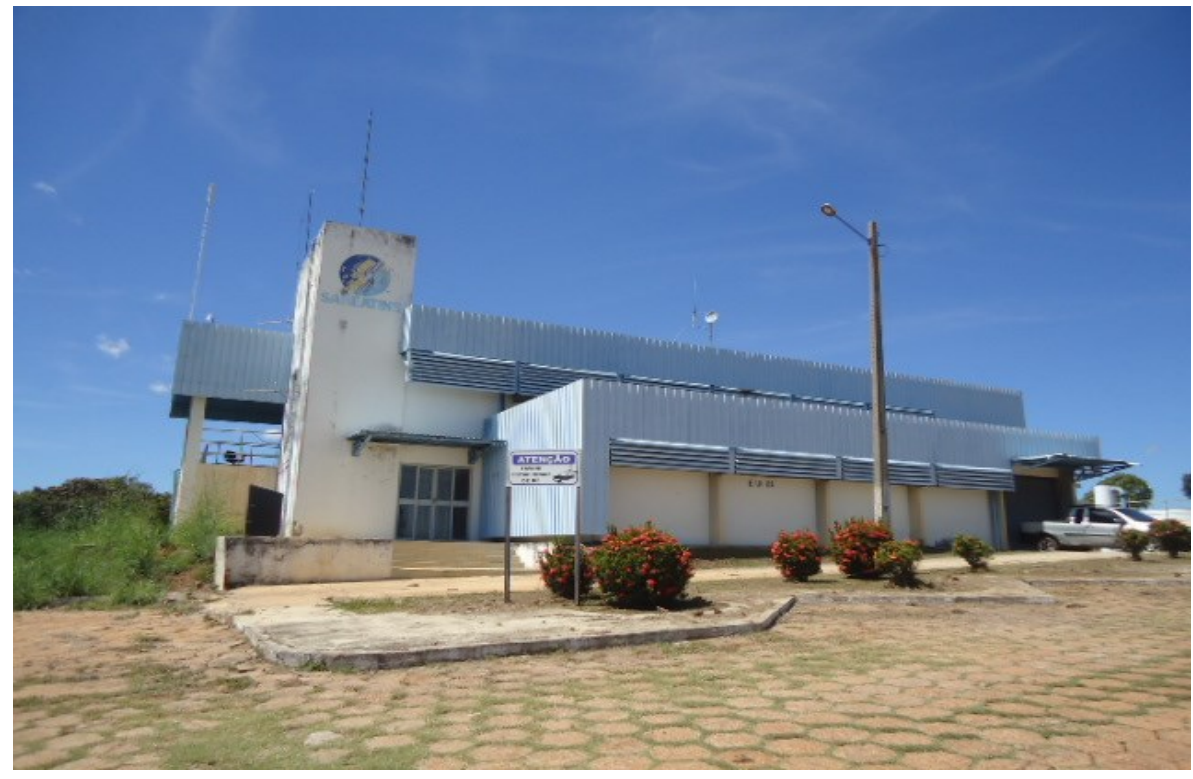

Fonte: Bernardeli, M. (abril 2017)

O local de tratamento de Porto Nacional possui dois sistemas, um antigo e um mais novo. Na ETA 02 (estrutura mais nova) a água bruta recebe os primeiros produtos químicos: hidróxido de cálcio e sulfato de alumínio ferroso líquido.

Na figura 16, temos a imagem dos filtros de lavagem instalados na ETA 02. Após a filtração, a água passa pelo processo de desinfecção, fluoretação e correção de $\mathrm{pH}$. A desinfecção é realizada pelo sistema Hidrogerox plus 36 , o qual utiliza sal como matéria prima para a produção da solução de cloro e flúor. Então, a água é 
armazenada e distribuída. A água de lavagem dos filtros segue para a lagoa de sedimentação e posteriormente retorna para ser tratada, realizando assim a recirculação da água e a redução de perdas no tratamento (PMAE, 2013).

FIGURA 16 - Filtros de Lavagem - ETA 02

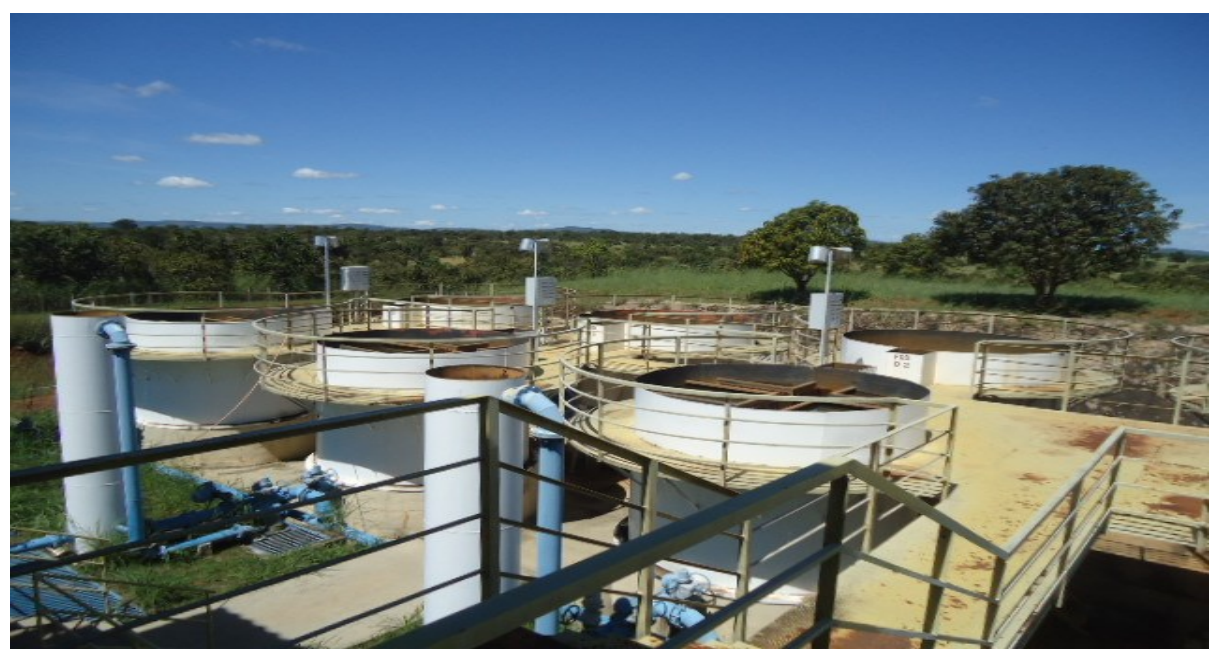

Fonte: Bernardeli, M. (abril 2017)

FIGURA 17 - Conjunto de Filtros - Dupla filtração

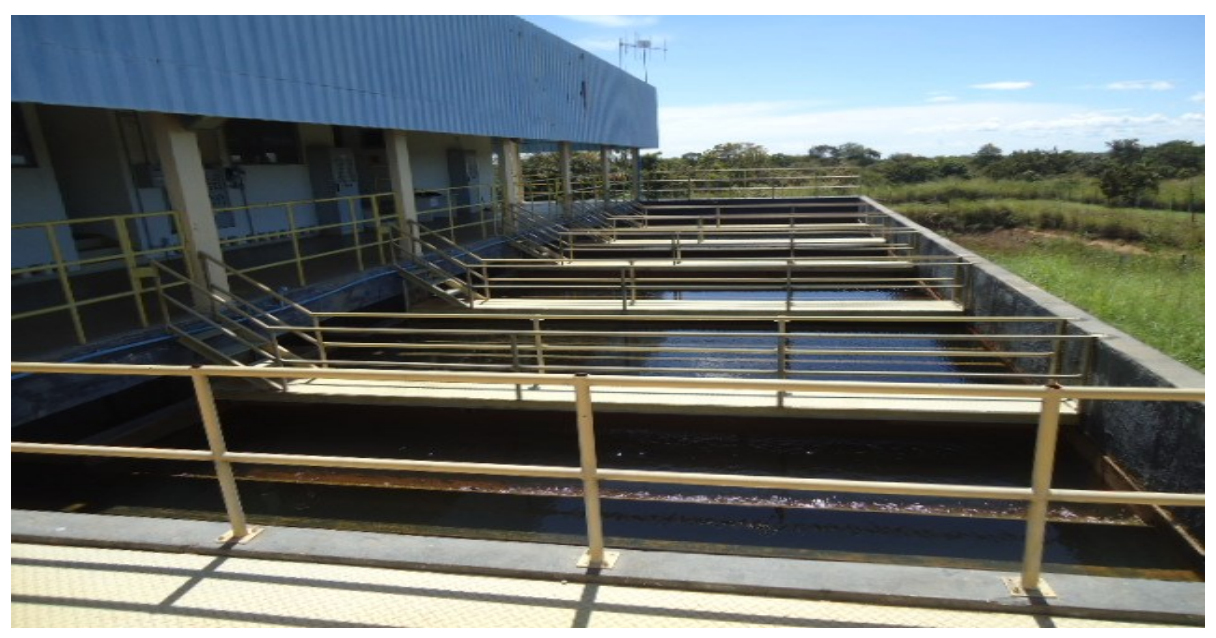

Fonte: Bernardeli, M. (abril 2017)

O plano municipal de água e esgoto de 2013 possui uma redação que destaca a eficiência do tratamento da água pela companhia de abastecimento público. 


\subsubsection{Reservação de água}

O PMAE (2013) apresenta que a reservação de água tratada em Porto Nacional encontra-se difusa em áreas estratégicas do município, promovendo assim uma melhor setorização das zonas piezométricas. É composta de dois reservatórios apoiados (RAP) e três reservatórios elevados (REL). O maior reservatório é o semienterrado RSE 01, apresentado na figura 18, está localizado na ETA 2, com capacidade de reservação de $2.700 \mathrm{~m}^{3}$ e a água para praticamente todo o sistema, a exceção do reservatório elevado da ETA 2, cuja água é recalcada diretamente do tanque de contato.

O reservatório elevado REL ETA 02, com capacidade de armazenar $125 \mathrm{~m}^{3}$, está localizado junto à ETA 2 (figura 19) e abastecem os seguintes setores: Conjunto Residencial Padre Luso, Parque Eldorado, Setor Nacional, Residencial Jardim das Mansões (expansão), Loteamento São Francisco, Parte do Conjunto Residencial Brigadeiro Eduardo Gomes, Parte da Vila Porto Imperial, Parte do Jardim Querido (PMAE, 2013).

FIGURA 18 - Reservatório RSE localizado na ETA 02

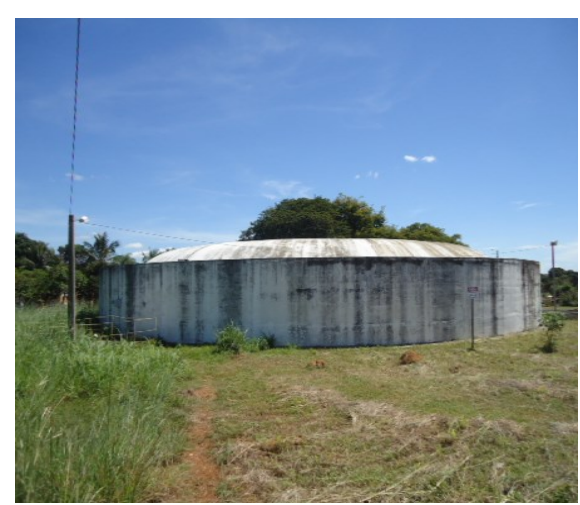

Fonte: Bernardeli, M. (abril 2017)
FIGURA 19 - Reservatório REL localizado na ETA 02

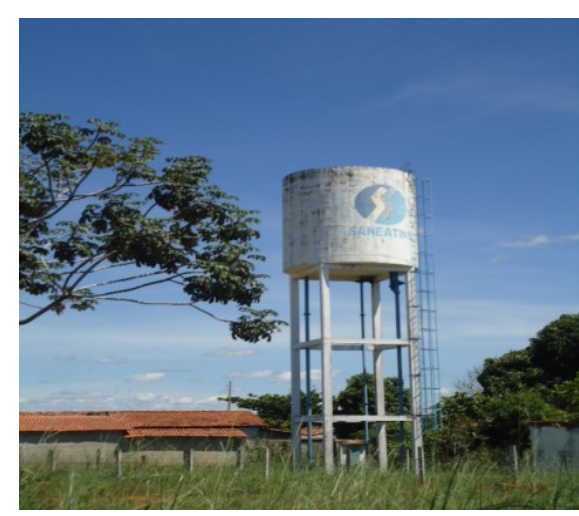

Fonte: Bernardeli, M. (abril 2017)

No escritório central da companhia de abastecimento, situado no setor Aeroporto, encontra-se um REL, com capacidade de armazenar $125 \mathrm{~m}^{3}$ (figura 20) e no setor Jardim dos Ipês encontram-se mais dois reservatórios um RAP e um REL (figura 21) esses últimos perfazem o total de $1.075 \mathrm{~m}^{3}$ de capacidade de armazenamento. 
FIGURA 20 - Reservatório REL localizado no escritório da cia de abastecimento

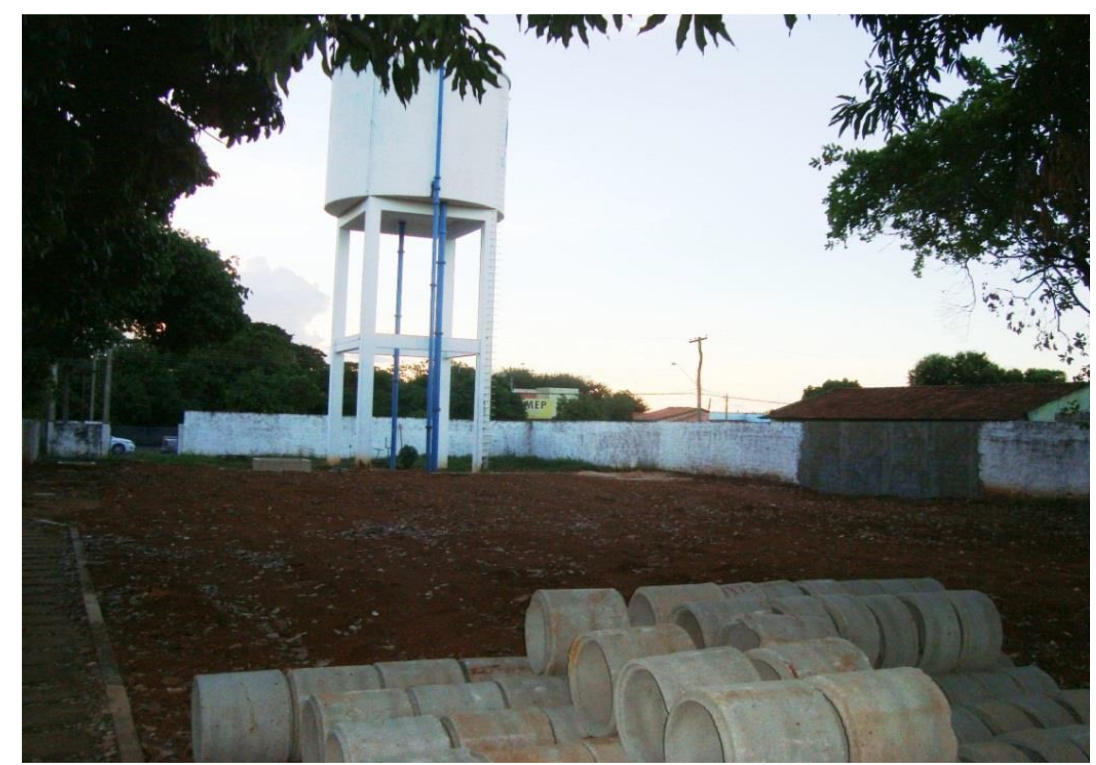

Fonte: (PMAE, 2013)

FIGURA 21 - Reservatório RAP e REL Ipês

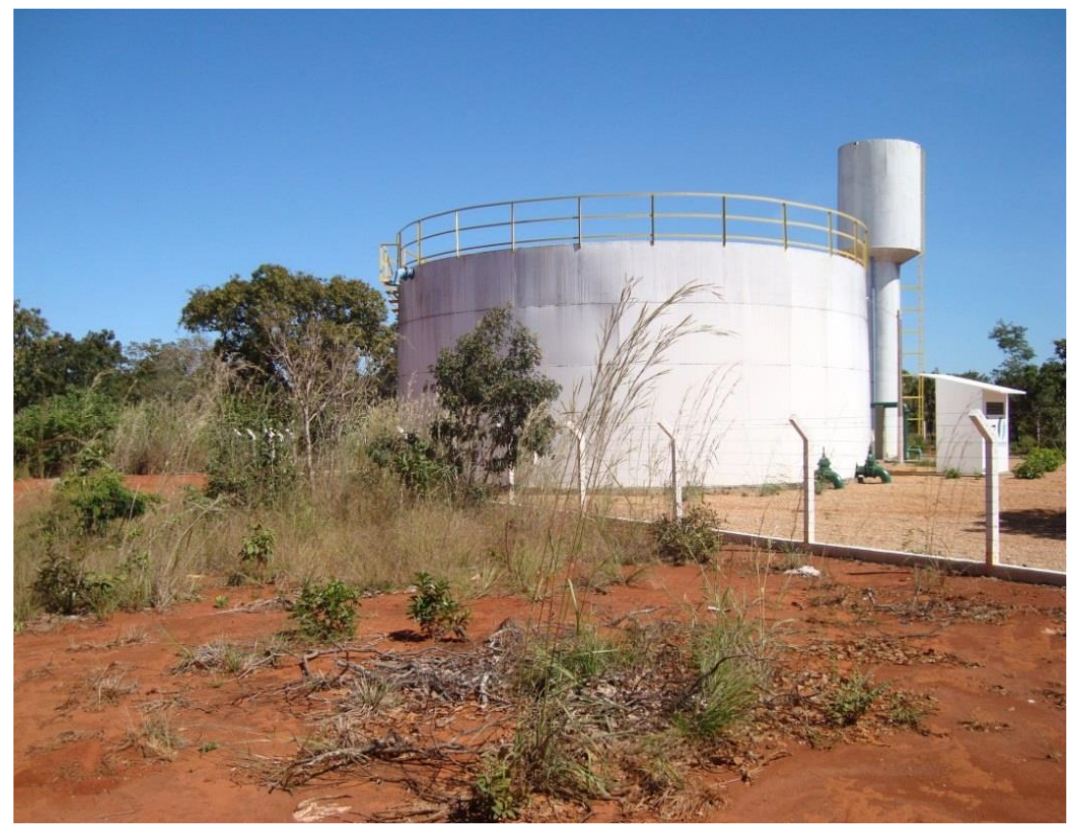

Fonte: (PMAE, 2013)

O quadro 7 relaciona a quantidade de reservatórios existentes na sede municipal de Porto Nacional, a sua capacidade de reservação, tipo de material e localização. 
QUADRO 7 - Reservatórios existentes na sede de Porto Nacional

\begin{tabular}{|c|c|c|c|c|}
\hline Reservatório & Capacidade $\left(\mathrm{m}^{3}\right)$ & Tipo & Material & Localização \\
\hline RSE & 2700 & Semienterrado & Concreto & ETA 002 \\
\hline REL & 125 & Elevado & Concreto & Adm. Central \\
\hline REL & 125 & Elevado & Concreto & Setor Ypê \\
\hline RAP & 1000 & Apoiado & Metálico & Setor Ypê \\
\hline REL & 75 & Elevado & Metálico & \\
\hline TOTAL & 4.025 & & &
\end{tabular}

Fonte: (PMAE, 2013)

\section{Consumo}

As ligações ativas de água na sede de Porto Nacional são distribuídas em quatro categorias, apresentadas no Quadro 8 o quantitativo e comparativo de ligações ativas por categoria, no mês de março nos anos de 2012, 2015, 2016 e 2017.

QUADRO 8 - Comparativo de Ligações Ativas de Água

\begin{tabular}{|l|l|l|l|l|}
\hline Tipo de categoria & Março/ 2012 & Março/ 2015 & Março/2016 & Março/ 2017 \\
\hline Residenciais & 12.135 & 14.669 & 15.537 & 17.048 \\
\hline Comerciais & 525 & 1.195 & 1.206 & 1.369 \\
\hline Públicas & 145 & 164 & 170 & 186 \\
\hline Industriais & 13 & 39 & 33 & 51 \\
\hline Total de Ligações & 13.374 & 16.067 & 16.946 & 18.654 \\
\hline
\end{tabular}

Fonte: PMAE 2013 e Cia de Saneamento 2017 Organizado: Bernardeli, M. 2017

Porto Nacional é uma cidade histórica, onde ainda possui muitas redes de cimento amianto (CA) material não mais utilizado pela companhia de saneamento, uma parte da rede ainda é desconhecida, mas a toda intervenção realizada na rede o cadastro é atualizado. A rede de distribuição é executada em malha com extensão aproximada de 255.949,73 metros em materiais e diâmetros diversos (PMAE, 2013). 


\section{APLICAÇÃO DO MODELO ANALÍTICO DE SEGURANÇA HÍDRICA NO SISTEMA DE ABASTECIMENTO DE PORTO NACIONAL-TO: RESULTADOS E DISCUSSÕES}

Conforme apresentado anteriormente, a segurança hídrica do abastecimento urbano, neste trabalho de dissertação, refere-se à gestão de riscos associados a diversos estressores que impactam ou podem impactar a disponibilidade de água bruta utilizada para abastecimento público, em quantidade e qualidade, tendo a bacia hidrográfica como referência. São também considerados aspectos associados à vulnerabilidade do sistema de abastecimento público de água, que podem ser mais ou menos adaptativos em relação à disponibilidade de quantidade e qualidade de água bruta.

Ou seja, a segurança hídrica global do abastecimento urbano de água, em termos de quantidade e qualidade de água bruta, é resultante da:

- Avaliação qualitativa do nível de segurança da disponibilidade de água bruta, associado a um determinado risco; e

- Avaliação qualitativa da vulnerabilidade do sistema de abastecimento urbano.

A aplicação do modelo no estudo de caso, iniciou-se, portanto, pela avaliação dos estressores na bacia hidrográfica do Córrego São João, a montante do ponto de captação, bem como seus impactos e riscos associados para a quantidade e qualidade de água captada para abastecimento urbano da sede municipal de Porto Nacional. Este conjunto informa o nível de segurança hídrica quali-quantitativo, perante cada estressor, que é associado a um determinado risco.

Em seguida, foi elaborado um cenário de vulnerabilidade, por meio da análise qualitativa e, por conseguinte, foram avaliadas as vulnerabilidades nos sistemas de abastecimento de água potável, da captação do sistema até o tratamento da água potável, considerando que a exposição de Sistema de abastecimento de água potável deriva do resultado da gestão da água bruta.

\subsection{Segurança hídrica associada à água bruta}

Serão analisados os cinco estressores da água bruta do modelo analítico: pressão sobre as condições ambientais da bacia, demanda por água (pressão sobre 
a quantidade), carga poluidora (pressão sobre a qualidade), eventos hidrológicos extremos (seca e inundações) e acidentes acidentais, de fontes fixas e móveis.

Para cada estressor, nesta etapa, é feita a sua caracterização na bacia hidrográfica do sistema de abastecimento da sede de Porto Nacional, a identificação do seu impacto, as ações de gestão que atualmente são executadas e que têm o propósito de atuar sobre o efeito do estressor e, por fim, a avaliação do risco associado ao estressor.

Neste estudo, foram utilizados, tratados e sistematizados, conforme metodologia proposta, os dados e informações disponibilizados pela Secretaria de Meio Ambiente e Recursos Hídricos do Estado de Tocantins (SEMARH), Instituto Natureza do Tocantins (NATURATINS), Instituto de Terras do Tocantins (ITERTINS), Companhia de Saneamento do Tocantins (SANEATINS), Diretoria Municipal do Meio Ambiente de Porto Nacional, Comitê da Bacia Hidrográfica do Lago de Palmas e Ministério Público do Estado do Tocantins (MPE-TO).

\subsubsection{Estressor da água bruta (1): pressão sobre as condições ambientais}

A "pressão sobre as condições ambientais" a montante do ponto de captação da ETA 02 é consequente particularmente da expansão agrícola. O parcelamento do solo e a expansão urbana ainda não atingiram a zona a montante do ponto de captação, embora estejam próximos e a tendência recente indique sua ampliação. Esse estressor será mensurado de forma qualitativa por meio de análise dos mapas temáticos de uso/ocupação e cobertura da terra, a determinação dos polígonos de intervenção antrópica e, por fim as áreas de preservação permanente fluvial.

\subsubsection{Uso e ocupação da terra e cobertura vegetal na bacia}

O mapa de uso da terra foi confeccionado a partir de um arquivo shape e importado para o banco de dados geográficos da bacia hidrográfica do Córrego São João e convertidos para um PI temático em linha/polígonos e matriz, possibilitandose representar a área ocupada por cada classe temática na bacia em estudo. Foram mapeadas feições relativas às i) formações florestais, ii) vegetação campestre, iii) corpos hídricos, iv) mancha urbana e v) solo descoberto e vi) uso antropizado. 
Posteriormente, foi realizada a avaliação do uso da terra na bacia de interesse, em 2006, 2011 e 2016. Esta apreciação tem o objetivo de fazer uma classificação de forma macro à alteração do uso da terra neste período em toda a bacia do Córrego São João. Esta avaliação complementa a anterior, uma vez que detalha a densidade de ocorrência da cobertura vegetal no território.

Por fim, foram calculados os valores de área e respectivos percentuais de cobertura das classes mapeadas em cada ano da bacia de contribuição no ano de 2006, 2011 e 2016, cujos resultados são apresentados a seguir.

Segundo Rosa (2007), o estudo do uso e da ocupação da terra consiste em buscar conhecimento de toda a sua utilização por parte do homem ou, quando não utilizado pelo homem, a caracterização dos tipos de categorias de vegetação natural que revestem o solo, como também suas respectivas localizações.

Além da classificação do uso do solo, também foi aplicada técnica complementar de geoprocessamento e sensoriamento remoto sobre as imagens de satélite, com o intuito de estimar a situação da vegetação nas porções territoriais em análise, com base no comportamento espectral desse alvo, elaborou-se uma chave de interpretação utilizada no processo de classificação de imagens (figura 22). 
FIGURA 22 - Chave de interpretação utilizada no processo de classificação de imagens

\begin{tabular}{|c|c|c|c|}
\hline \multicolumn{4}{|c|}{ CHAVE DE INTERPRETAÇÃO } \\
\hline \multirow[t]{2}{*}{ Classe } & \multirow[t]{2}{*}{ Foto } & \multicolumn{2}{|l|}{ Composição colorida } \\
\hline & & 5R, 4G, 3B (Landsat 7) & 6R, 5G, 4B (Landsat 8) \\
\hline \multicolumn{4}{|l|}{ Formações } \\
\hline \multicolumn{4}{|l|}{ Florestais } \\
\hline \multicolumn{4}{|l|}{ Vegetação } \\
\hline \multicolumn{4}{|l|}{ Corpos } \\
\hline \multicolumn{4}{|l|}{ Hídricos } \\
\hline \multicolumn{4}{|l|}{ Mancha } \\
\hline \multicolumn{4}{|l|}{ Urbana } \\
\hline \multicolumn{4}{|l|}{ Solo } \\
\hline \multicolumn{4}{|l|}{ Descoberto } \\
\hline \multirow{2}{*}{\multicolumn{4}{|c|}{$\begin{array}{l}\text { Uso } \\
\text { Antropizado }\end{array}$}} \\
\hline & & & \\
\hline & & & \\
\hline & & & \\
\hline
\end{tabular}

Org. Bernardeli, M. (2017) 
As classes de uso e ocupação da terra apresentadas na Tabela 2, com as respectivas áreas e os percentuais em relação ao total da bacia hidrográfica do Córrego São João, permitem identificar as áreas de formações florestais que exercem uma relevante função ecológica na região, onde se encontra a barragem de acumulação de água para captação do abastecimento urbano da sede municipal de Porto Nacional.

TABELA 2- Comparação do uso e ocupação da terra 2006, 2011 e 2016

\begin{tabular}{|c|c|c|c|c|c|c|}
\hline CLASSES & $\begin{array}{c}\text { Áreas (ha) } \\
2006\end{array}$ & $\%$ & $\begin{array}{c}\text { Áreas (ha) } \\
2011\end{array}$ & $\%$ & $\begin{array}{c}\text { Áreas } \\
\text { (ha) } 2016\end{array}$ & $\%$ \\
\hline $\begin{array}{l}\text { Formações } \\
\text { Florestais }\end{array}$ & $3.322,23$ & $41,05 \%$ & $3.129,38$ & $38,67 \%$ & $2.864,72$ & $35,40 \%$ \\
\hline $\begin{array}{l}\text { Vegetação } \\
\text { Campestre }\end{array}$ & $1.808,90$ & $22,35 \%$ & $2.278,95$ & $28,16 \%$ & $1.831,13$ & $22,62 \%$ \\
\hline $\begin{array}{l}\text { Corpos } \\
\text { hídricos }\end{array}$ & 112,55 & $1,39 \%$ & 114,22 & $1,41 \%$ & 112,92 & $1,40 \%$ \\
\hline $\begin{array}{l}\text { Mancha } \\
\text { urbana }\end{array}$ & 463,43 & $5,73 \%$ & 479,69 & $5,93 \%$ & 819,22 & $10,12 \%$ \\
\hline $\begin{array}{l}\text { Solo } \\
\text { descoberto }\end{array}$ & 482,73 & $5,96 \%$ & 54,84 & $0,68 \%$ & 186,99 & $2,31 \%$ \\
\hline Agropecuária & $1.903,71$ & $23,52 \%$ & $2.036,47$ & $25,16 \%$ & $2.278,57$ & $28,15 \%$ \\
\hline $\begin{array}{l}\text { Área total da } \\
\text { bacia }\end{array}$ & $8.093,55$ & $100,0 \%$ & $8.093,55$ & $100,0 \%$ & $8.093,55$ & $100,00 \%$ \\
\hline
\end{tabular}

Organizadora: Bernardeli, M.

Considerando-se a diferença de resolução radiométrica da imagem disponível em 2006, a avaliação comparativa no período em 2011 e 2016, permite identificar a expansão da mancha urbana e da agropecuária na porção da bacia, e esse uso inclui a agricultura. Destaca-se a diminuição da cobertura vegetal na bacia por formações florestais e por vegetação campestre e a expansão urbana na bacia aproximando-se do reservatório de água onde está localizado o ponto de captação para abastecimento urbano, apresentado no gráfico 1. 
GRÁFICO 1 - Comparação do uso e ocupação da terra nos anos 2006, 2011 e 2016 na bacia do Córrego São João

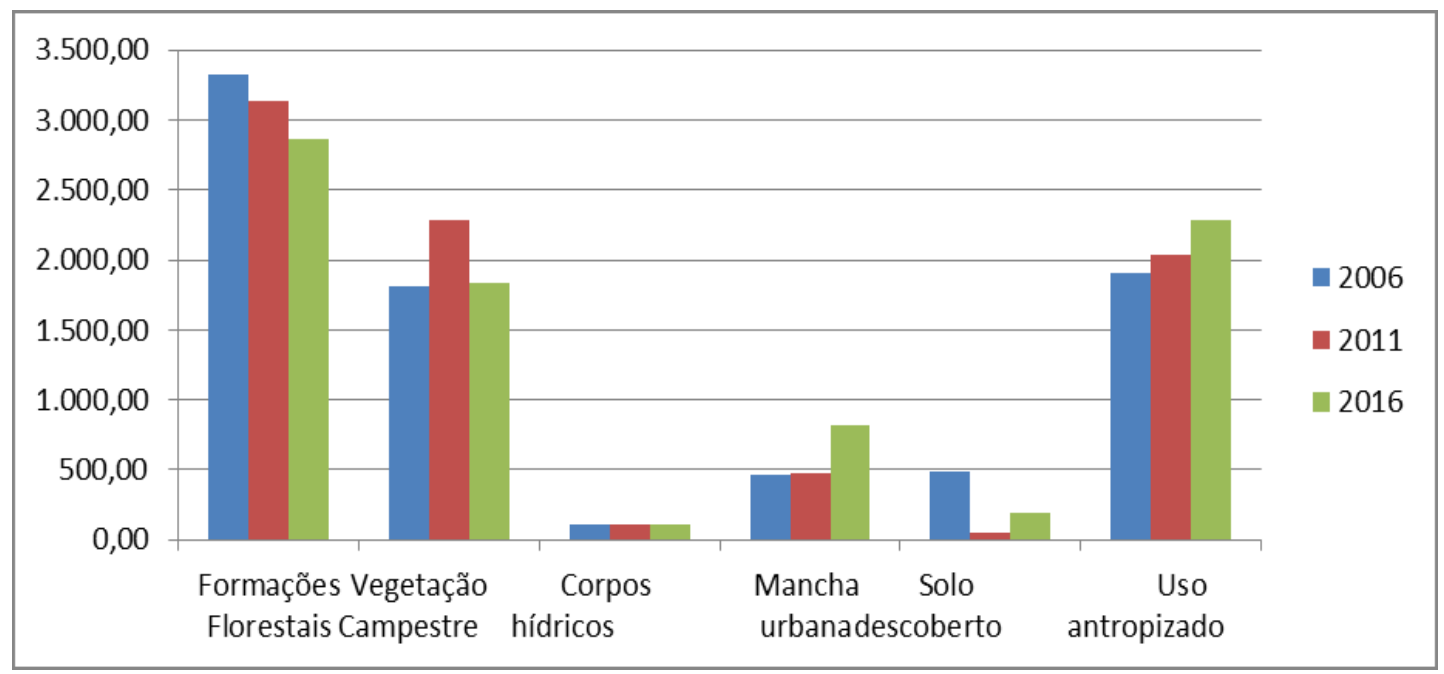

Fonte: Bernardeli, M

Cristo et al. (2006), ao estudarem esta mesma área, a bacia do Córrego São João, relataram no ano de 2006 a constatação das práticas agropecuárias na bacia, principalmente em seu médio e alto curso, onde as atividades agrícolas eram realizadas em áreas menores para produção de subsistência (milho, mandioca, cana-de-açúcar) e a pecuária extensiva com ocupação de grandes áreas para pastagens.

Leite (2011) realizou em sua pesquisa a detecção têmporo-espacial do uso e ocupação da terra na bacia do córrego São João no período de 1980 a 2010 e verificou que a evolução da malha urbana e a implantação de pastagens e de áreas agrícolas retirou a vegetação mais densa que caracterizava a bacia. Em 1980, essa classe ocupava $46,42 \%$ de área, já em 2010 houve uma redução para 26,81\%. Provocou-se, assim, a supressão e a fragmentação da vegetação, incidindo-se na qualidade ambiental da bacia que está intrinsicamente ligada proporcionalmente à mata mais densa, bem como as possíveis ligações entre a vegetação primária.

A partir dos mapas de uso e ocupação da terra da bacia hidrográfica do córrego São João no ano de 2006 (Figura 23), evidenciam-se os usos atuais e seus percentuais respectivos, para a compreensão no processo de ocupação e comparação durante os anos estudados. No ano de 2006, as formações florestais representavam $41,05 \%$ da área da bacia e a mancha urbana ocupava $5,73 \%$.

No ano de 2006, a bacia encontrava-se com mais de 35\% de área modificada, somando as seguintes classes: mancha urbana, solo descoberto e agropecuária, principalmente no médio e baixo curso da bacia. 
Leite (2011) comenta que a constante abertura de novas áreas para aproveitamento agropecuário, bem como a expansão de áreas urbanas, tem deixado marcas na superfície terrestre, determinadas pelo uso e ocupação da terra, com uma consequente supressão e fragmentação da vegetação primária.

As degradações em áreas de preservação ambiental envolvem as margens dos rios e suas matas ciliares, ocasionando danos tanto no solo, quanto na qualidade da água e na capacidade produtiva da bacia. Por isso, é preciso assegurar a conservação desses recursos para que sejam utilizados de forma sustentável pela população, respeitando a legislação vigente (GUERRA et al., 2010). 
FIGURA 23 - Uso e ocupação da terra - 2006

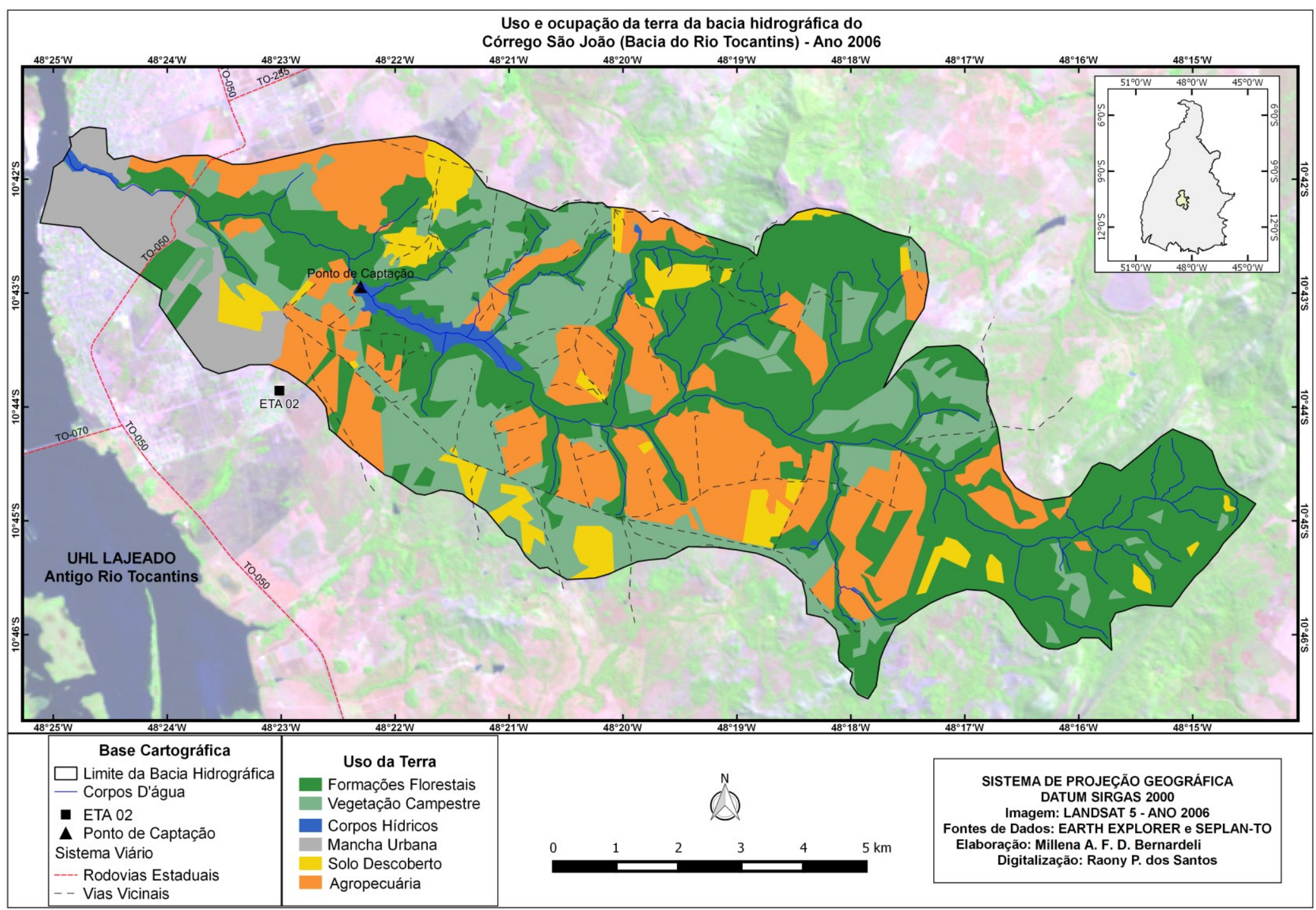


Na caracterização do uso e ocupação da terra, em 2011, conforme a Figura 24 , percebe-se um decréscimo nas formações florestais de $3 \%$ na área total da bacia, entretanto a classe de solo descoberto diminuiu $5 \%$ e a vegetação campestre aumentou $6 \%$ aproximadamente.

Os moradores da bacia, na área da zona rural, relataram que a dinâmica da vegetação mudou consideravelmente no período de 2011 a 2016, registrando por meio da observação direta, a retirada da vegetação densa para a plantação de monoculturas, alguns relataram que foram ofertados arrendamentos de porções de sua propriedade, referentes a 100 hectares, pelo pagamento mensal de $\mathrm{R} \$ 5.000,00$ e esse valor pode representar uma renda bastante superior àquela com a qual alguns moradores estão habituados.

Para a comparação das porções sul e noroeste da bacia, identificadas como solo descoberto em 2006 e após o período de cinco anos, o mapa de 2011 permite verificar que as mesmas áreas da bacia apresentaram um aumento de aproximadamente seis por cento da vegetação campestre. Alguns moradores da bacia informaram que nesse período houve uma interrupção no plantio na terra preparada por produtores de soja, que haviam iniciado o preparo da terra em 2011, mas não efetivaram o plantio da monocultura e relataram também a diminuição da pecuária extensiva nas fazendas e chácaras presentes na bacia. 
FIGURA 24 - Uso e ocupação da terra - 2011

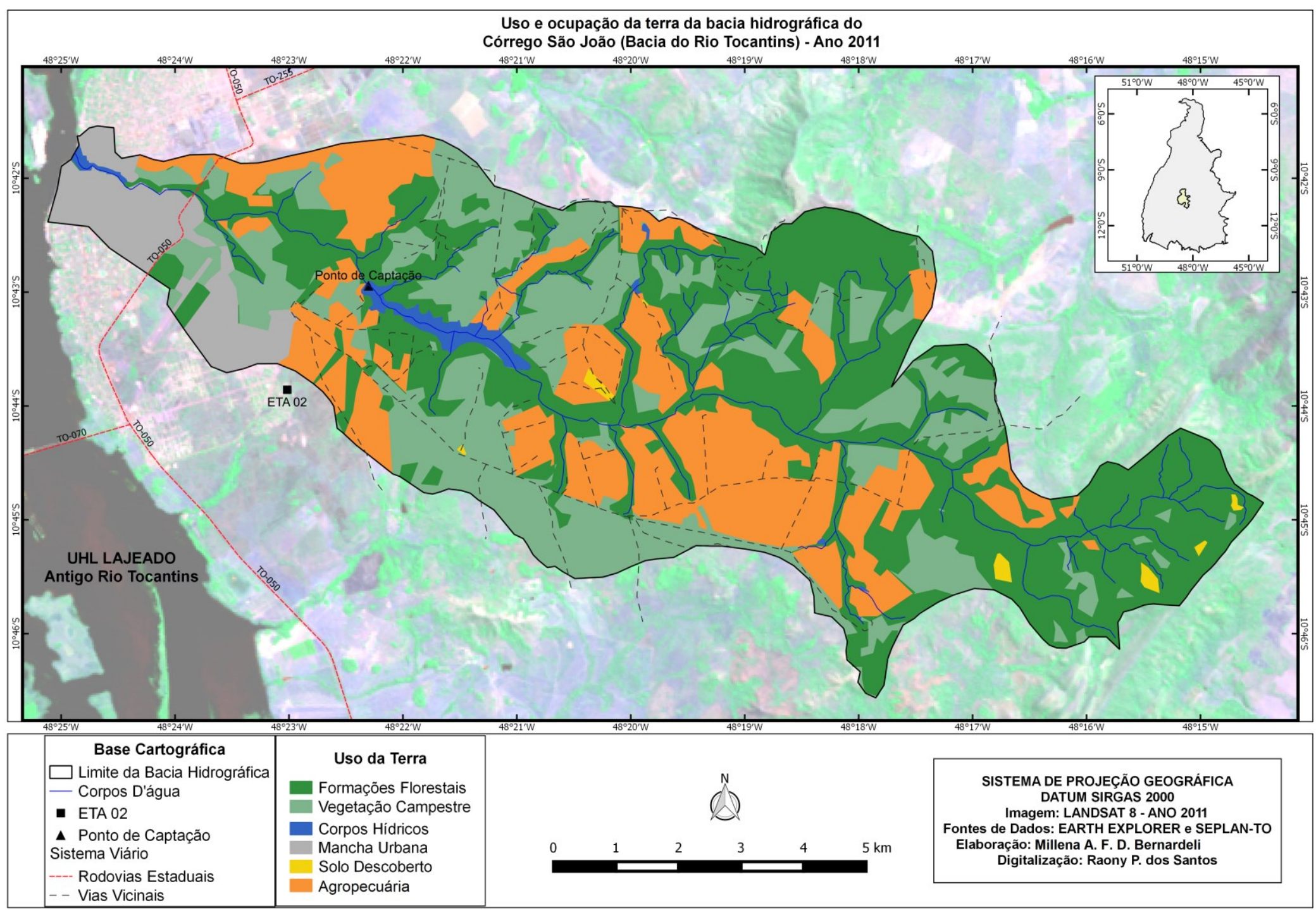


Ao percorrer a bacia nos anos de 2015, 2016 e meados de 2017, podemos observar uma contínua mudança na dinâmica da vegetação, decorrente do desmatamento da vegetação original da bacia, seja acima do ponto de captação de água para o abastecimento, como também no trecho urbano da bacia para a implantação de três novos loteamentos próximos ao reservatório.

A autora registrou a utilização de maquinários pesados na preparação das áreas para a produção de monoculturas, na zona rural da bacia, acima do ponto de captação do sistema de abastecimento (Figuras 25, 26 e 27). Percebe-se que a bacia não possui mais um potencial de pecuária extensiva como na década de 1990 e nos anos 2000.

FIGURA 25 - Corrente usada em ação de desmatamento na bacia outubro de 2015

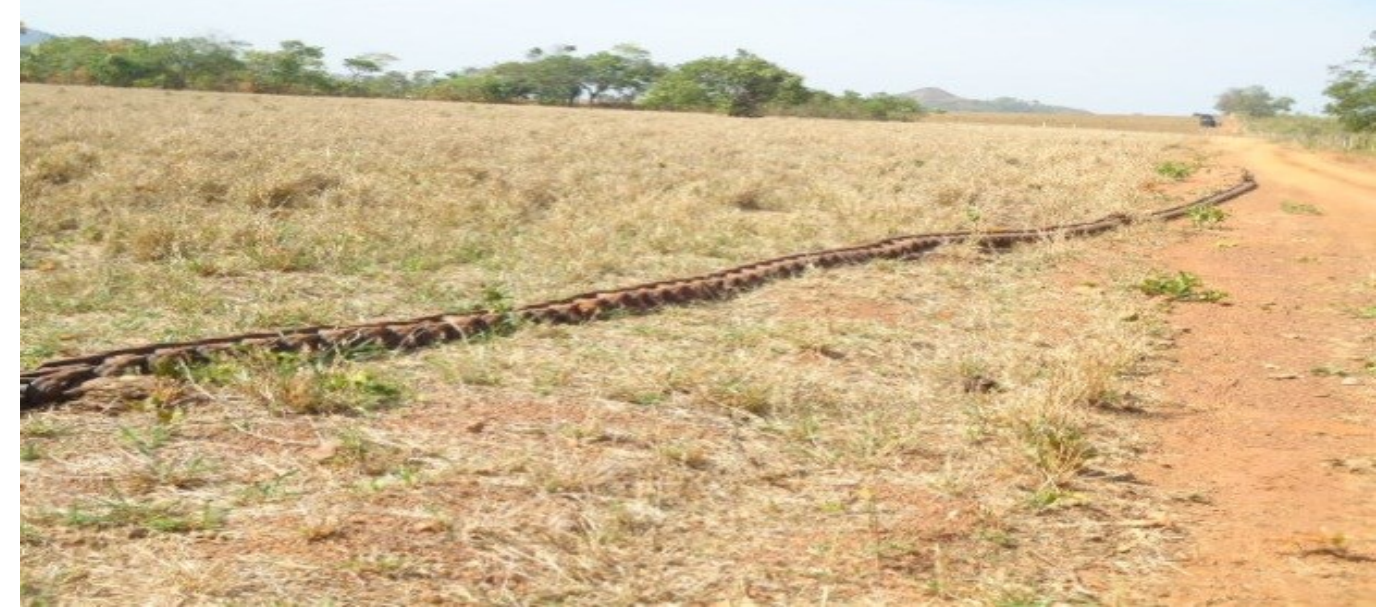

Fonte: Bernardeli, M. (2015)

FIGURA 26 - Presença de maquinário para desmatamento na bacia outubro de 2015

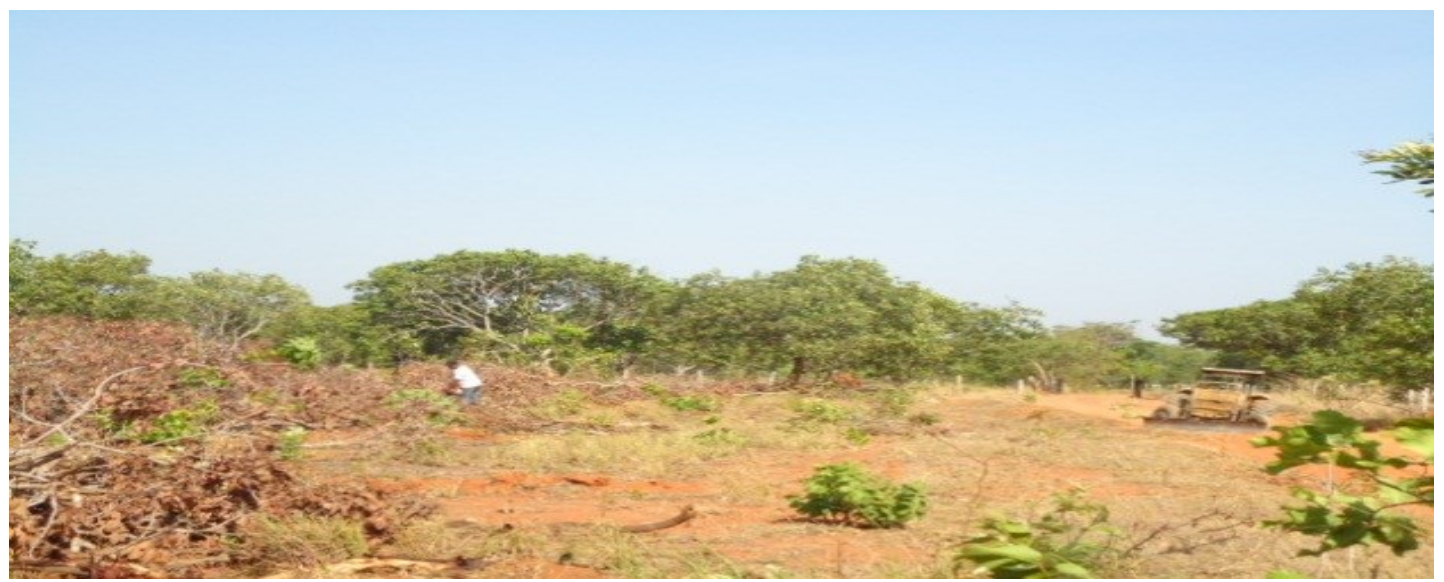

Fonte: Bernardeli, M. 2015) 
FIGURA 27 - Área recém desmatada na bacia outubro de 2015

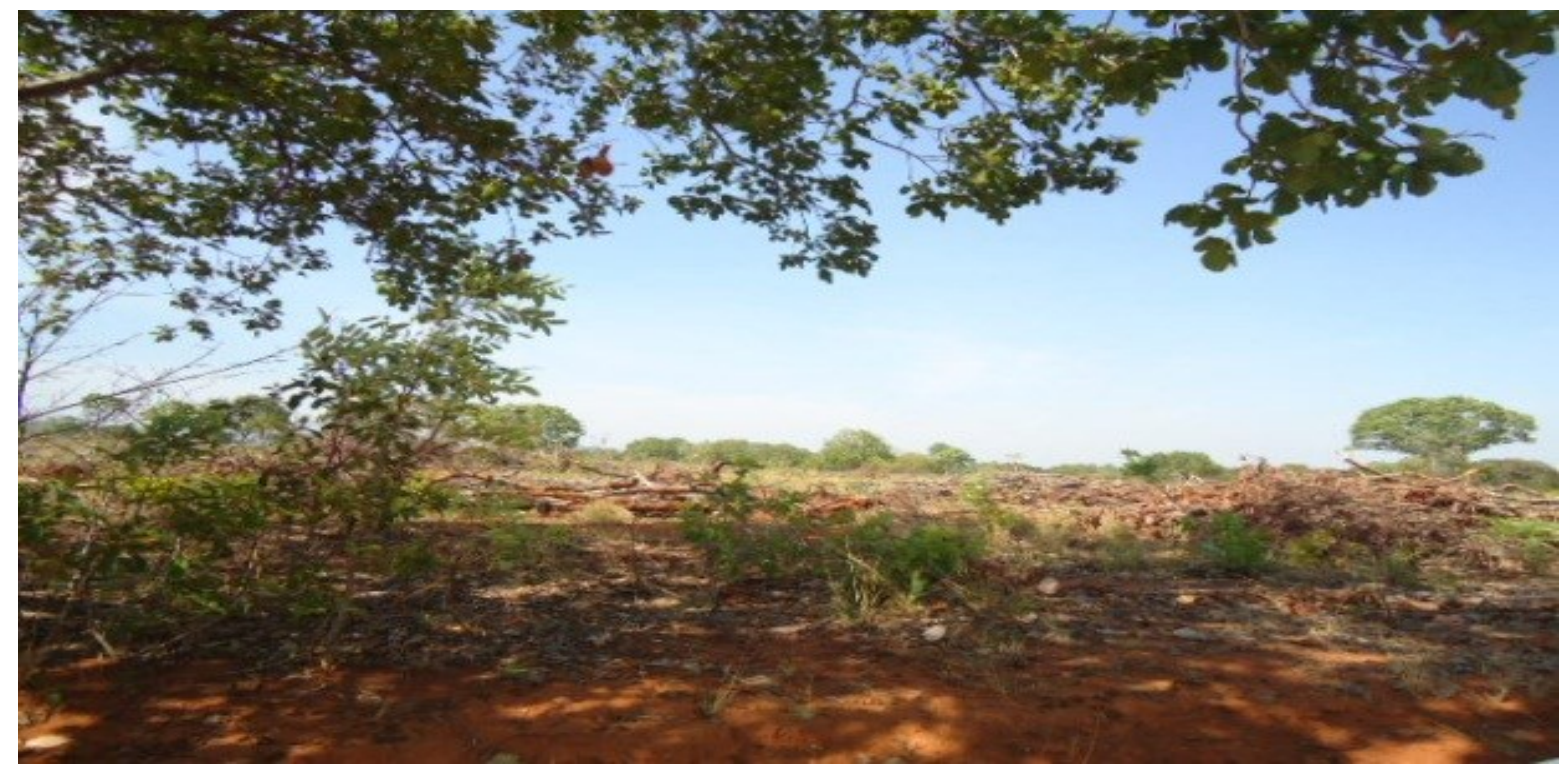

Fonte: Bernardeli, M. 2015)

Alguns moradores de fazendas e chácaras, visitadas pela autora nos anos de 2015, 2016 e 2017, e que primam pela preservação da mata nativa de suas propriedades, relataram a presença de animais silvestres alimentando-se de frutas e verduras presentes em seus pomares e hortas, situação que se repete nos últimos dois anos e que pode indicar um comprometimento dos habitats e da disponibilidade de alimentos na natureza.

Por fim, constatou-se, durante as incursões realizadas, em alguns trechos da bacia e após análise dos mapas de uso e ocupação da terra, o avanço da monocultura da soja, que deixou marcas significativas na área estudada, pressionando a terra, a fauna e a flora, ocorrendo à consolidação gradual, especialmente da margem esquerda do córrego São João, em área agrícola, apresentada na figura 28 , quanto mais modernizada a atividade agrícola maior são suas relações e alcance. 
FIGURA 28 - Uso e ocupação da terra - 2016

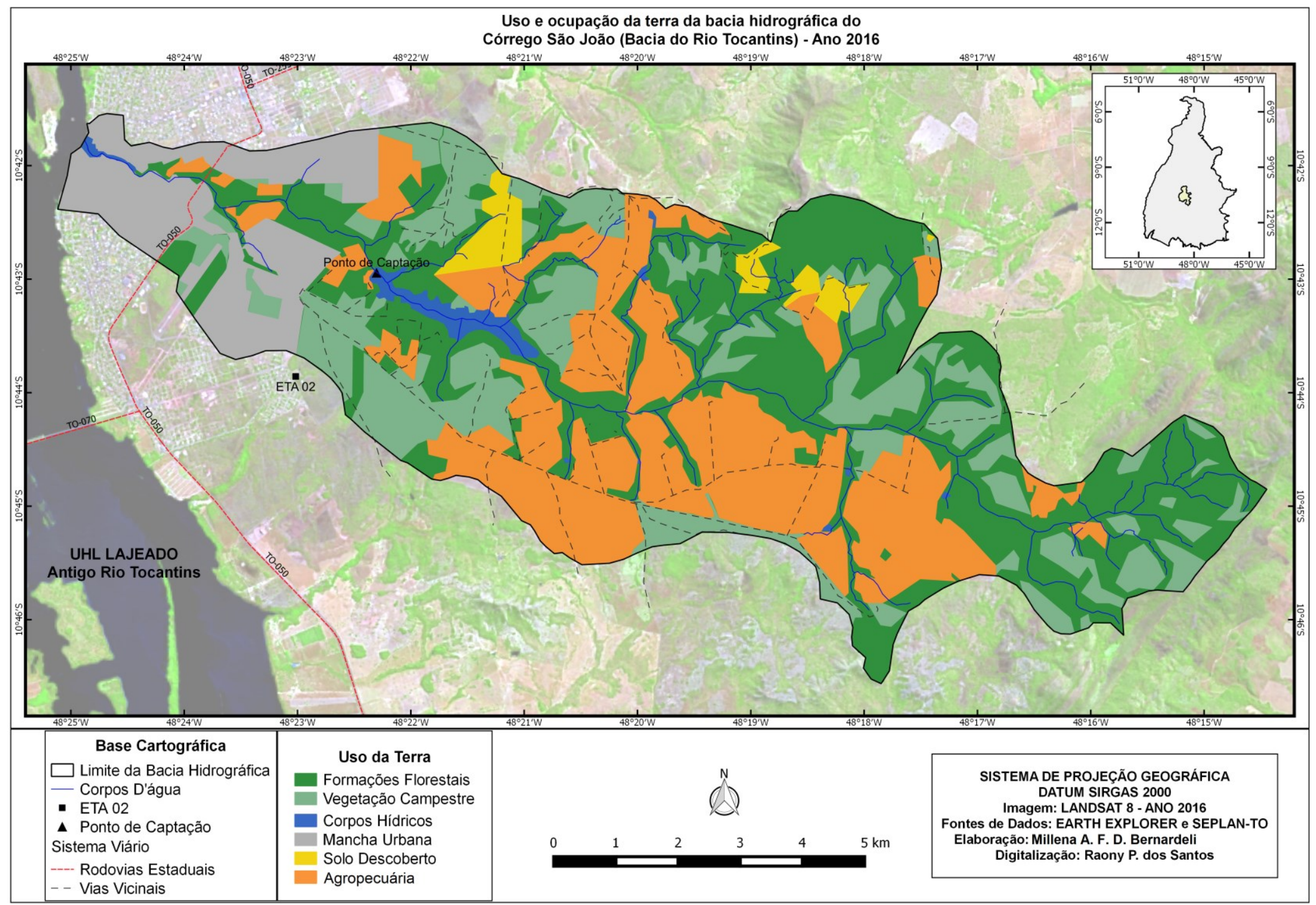




\subsubsection{2 Área de Preservação Permanente - APP Fluvial}

Conforme ilustrações na tabela 3 e Figuras 29 e 30, as porções com APPs comprometidas se associam aos solos descobertos $(14,47 \%)$ e usos antropizados $(2,17 \%)$, totalizando $16,64 \%$ de supressão da vegetação das APPs. Salienta-se um desmatamento nas vegetações florestais nas APPs da barragem de acumulação de água, o que pode ocasionar um impacto direto na qualidade e na quantidade de água.

TABELA 3 - Uso e Ocupação das APPs da Bacia Hidrográfica do Córrego São João, município de Porto Nacional Tocantins (2006 e 2016).

\begin{tabular}{l|c|c|c|c}
\hline \multicolumn{1}{c|}{ Classes } & $\begin{array}{c}\text { Área (ha) ano } \\
2006\end{array}$ & $\%$ & $\begin{array}{c}\text { Área (ha) ano } \\
2016\end{array}$ & $\%$ \\
\hline Vegetação Campestre & 78,593449 & $21,6 \%$ & 85,980829 & $23,63 \%$ \\
\hline \begin{tabular}{l} 
Vegetação Florestal \\
\multicolumn{1}{c|}{ Área Descoberta }
\end{tabular} & $\mathbf{2 6 2 , 4 0 3 8 9 6}$ & $72,1 \%$ & 210,680696 & $57,90 \%$ \\
\hline $\begin{array}{l}\text { Corpos antrópicas } \\
\text { continentais }\end{array}$ & 10,246915 & $2,8 \%$ & 6,654953 & $1,83 \%$ \\
\hline \begin{tabular}{l} 
Área Urbanizada \\
\hline Áreas \\
agrícolas
\end{tabular} & 1,195807 & $0,3 \%$ & 4,202894 & $1,16 \%$ \\
\hline Área total das classes & 363,877463 & $100,0 \%$ & 363,877463 & $100,00 \%$ \\
\hline
\end{tabular}

Fonte: Bernardeli, M.

As vegetações florestais correspondem atualmente a apenas $57,90 \%$ da área devida, sendo que houve uma perda de $15 \%$, comparando-se com os $72,1 \%$ que perfaziam o total desta classe no ano de 2006. A proteção nativa das APPs deste manancial, em dez anos, foi degradada, e especialmente no baixo e médio curso da bacia do córrego São João que se encontram cada vez mais antropizados. 
GRÁFICO 2 - Comparação das APPs fluviais nos anos 2006 e 2016

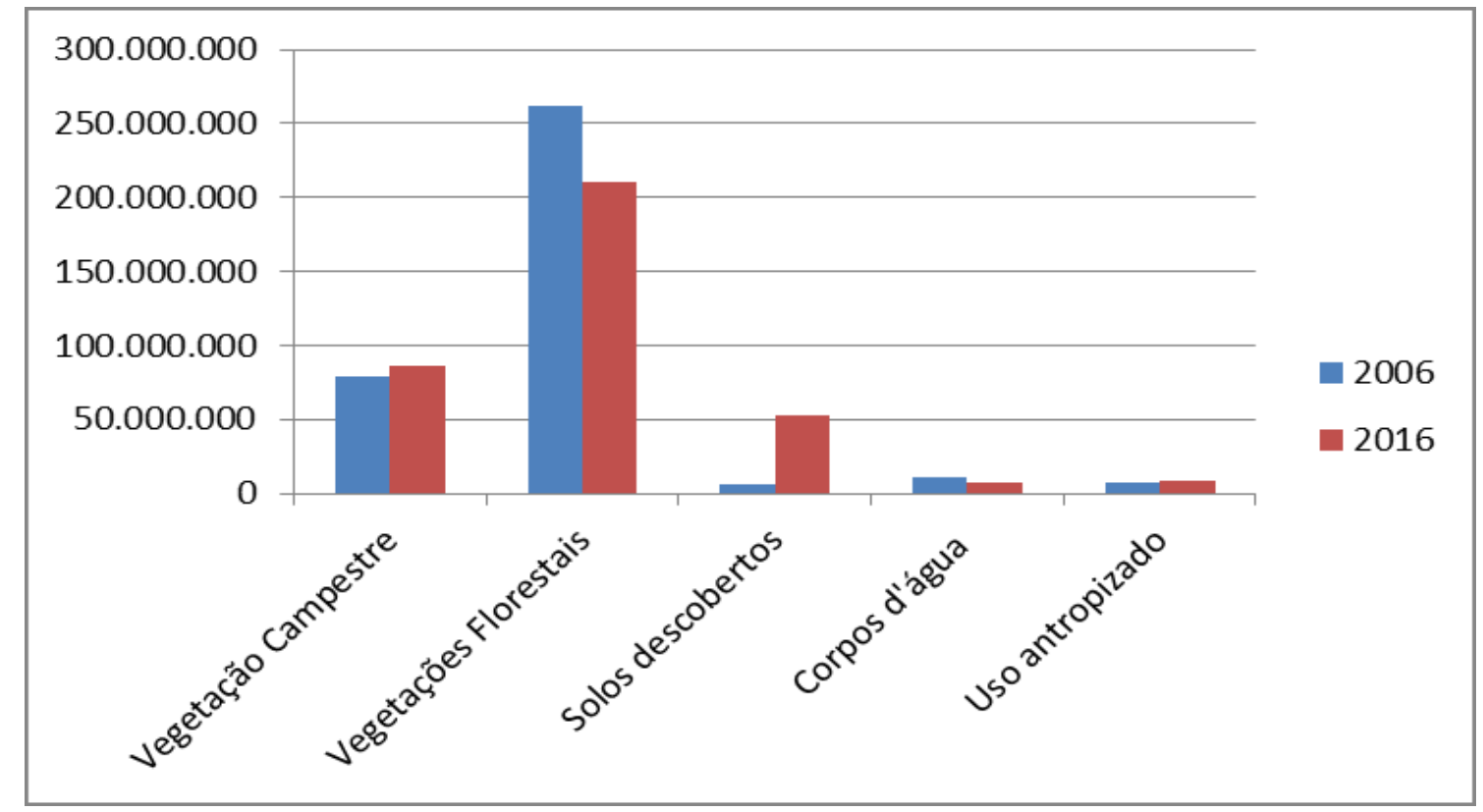

Fonte: Bernardeli, M.

O mapa de uso e ocupação das APPs fluviais da bacia do Córrego São João (figuras 29 e 30) demonstra uma incidência maior de solos descobertos com acentuada supressão da vegetação florestal. Como consequência, abre caminho para o início do processo erosivo, por causa da declividade que facilita o transporte de sedimentos, ocorrendo o escoamento superficial e impactando a calha do rio. 
FIGURA 29 - Situação das APPs Fluviais na área de contribuição do Córrego São João 2006

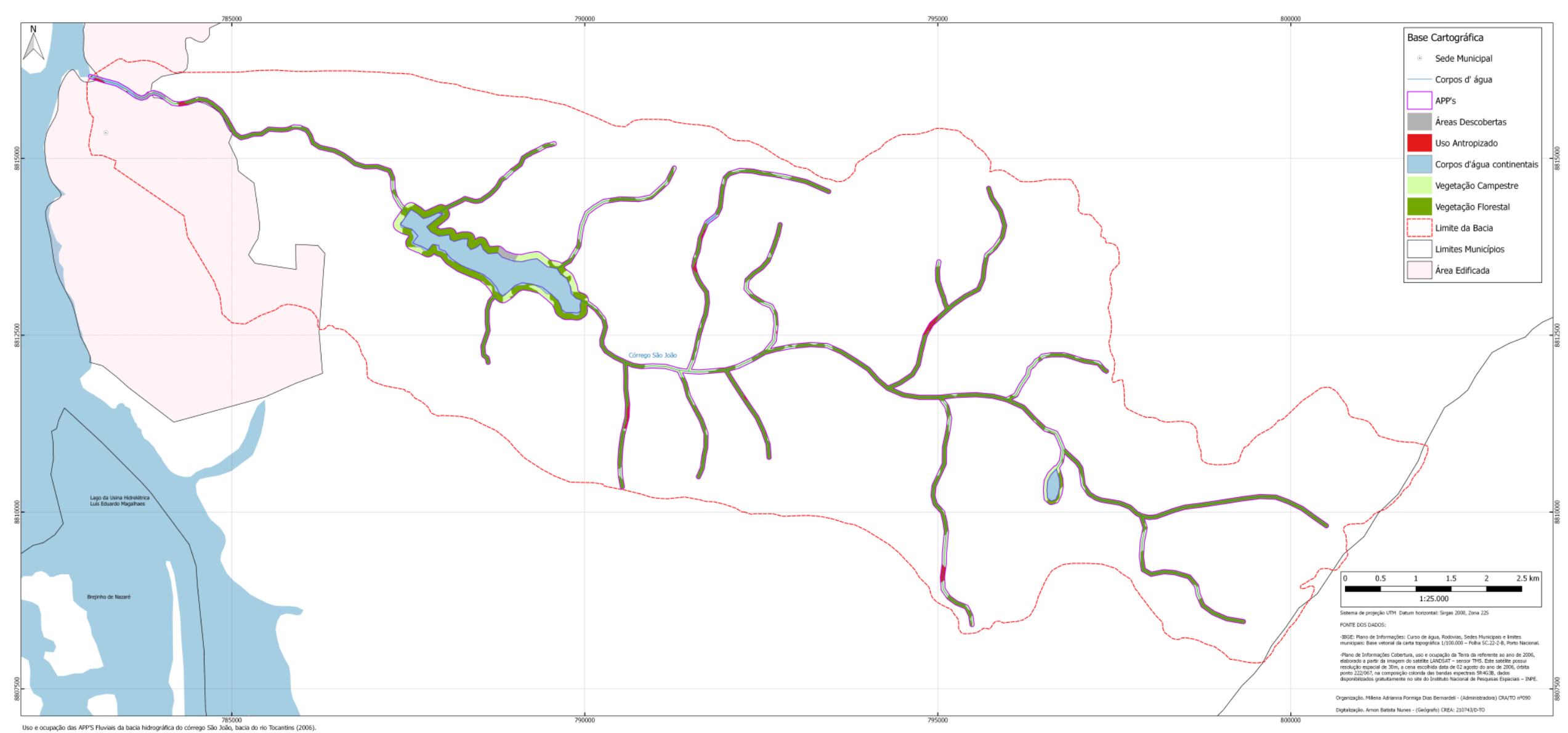


FIGURA 30 - Situação das APPs Fluviais na área de contribuição do Córrego São João 2016

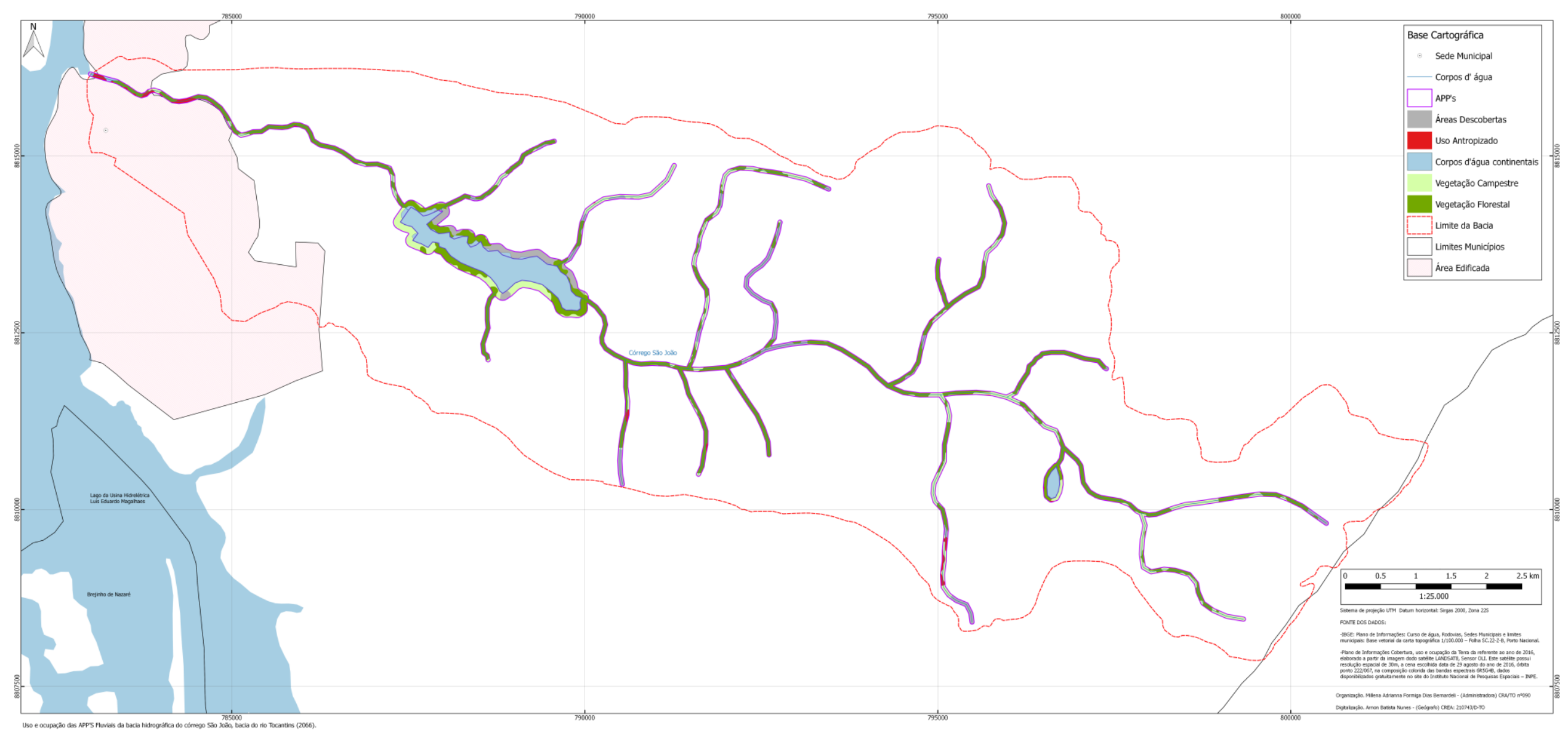


A expansão dos loteamentos, o aumento da sojicultura, áreas com solos degradados e abandonados e a ausência de mata ciliar tornam-se importantes fontes difusas de poluição em toda a bacia. A forma com que a terra vem sendo usada e ocupada pode causar alterações nos processos hidrológicos e prejuízos na qualidade da água da bacia do Córrego São João.

Um dos entrevistados (proprietário de uma chácara de 10 alqueires situada acima do ponto de captação) informou que devido à falta de água em sua propriedade no ano de 2016 abriu um poço com profundidade de 26 metros e não encontrou água.

\section{$\underline{\text { 5.1.1.3 Síntese do estressor }}$}

Para dar uma visão geral da situação do estressor "Pressão sobre as condições ambientais da Bacia", a Tabela 3 resume as características do uso e ocupação da terra, relativas ao ano de 2016, que foram mensuradas neste trabalho de dissertação.

TABELA 4 - Pressão sobre as condições ambientais - 2016

\begin{tabular}{l|l|l|l}
\hline \multicolumn{3}{c}{ PRESSÃO SOBRE AS CONDIÇÕES AMBIENTAIS } \\
\hline \multicolumn{1}{c}{$\begin{array}{c}\text { Característica } \\
\text { mensurável }\end{array}$} & \multicolumn{1}{c}{ Parâmetro } & Área (ha) & Percentual \\
\hline $\begin{array}{l}\text { Uso e ocupação da } \\
\text { terra }\end{array}$ & $\begin{array}{l}\text { Área antropizada e } \\
\text { mancha urbana (ha) }\end{array}$ & $3.097,79$ & $38,27 \%$ \\
\hline $\begin{array}{l}\text { Desmatamento da } \\
\text { cobertura vegetal na } \\
\text { bacia } \\
\text { (exceto a área de } \\
\text { preservação } \\
\text { permanente - APP } \\
\text { fluvial) }\end{array}$ & Área desmatada (ha) & $3.284,78$ & $\begin{array}{l}\text { do total da } \\
\text { bacia }\end{array}$ \\
\hline $\begin{array}{l}\text { Degradação da } \\
\text { cobertura vegetal na }\end{array}$ & $\begin{array}{l}\text { Área sem cobertura } \\
\text { vegetal APP Fluvial } \\
\text { (ha) }\end{array}$ & 60,56 & $\begin{array}{l}\text { *16,64\% } \\
\text { do total de } \\
\text { APPs da bacia }\end{array}$ \\
\hline \hline
\end{tabular}

Nota: * percentual em relação ao total de APP na bacia

Organizadora: Bernardeli, M. 
Da área total da bacia, 58,2\% têm cobertura vegetal e $28,15 \%$ da área é abrangida por algum tipo plantação. Em relação às ações atualmente iniciadas para gerenciar o estressor aqui discutido, destaca-se que a porção a montante do ponto de captação não possui unidade de conservação.

Há instrumentos legais para proteção ambiental da bacia no âmbito estadual e municipal, mas não são aplicadas em tempo hábil, as áreas de preservação permanentes poderiam desempenhar funções especificas de proteção dos mananciais e subsidiar programas para esta função.

Os efeitos desse estressor, conforme apresentado, são difusos na bacia e, portanto, de difícil correlação direta com a qualidade e a quantidade da água necessitando de estudos específicos para a sua determinação.

\section{$\underline{\text { 5.1.1.5 Análise de Risco }}$}

Com base na avaliação semi-quantitativa da "pressão sobre as condições ambientais da Bacia", foi estimado o risco para a quantidade e qualidade de água, no ponto de captação da ETA 02 (Figura 31):

- Avaliou-se que a ocorrência do estressor é de média intensidade porque há uma crescente antropização da área a montante da captação, sobretudo por conta da expansão agrícola. Este estressor tende cada vez mais a pressionar a bacia e seus corpos d'água. Além do mais, a expansão urbana, que se situa a jusante do ponto de captação, vem aumentando de forma significativa e se aproximando do ponto de captação, correndo o risco de ocupar a área a montante.

- Quanto ao impacto, avaliou-se como sendo de alta severidade, principalmente pela consequente redução da vegetação e pelos impactos associados à agropecuária em áreas que devem ser minimamente protegidas por ser o único manancial de abastecimento da sede municipal de Porto Nacional. 
FIGURA 31 - Matriz de risco associado à pressão sobre as condições ambientais da Bacia.

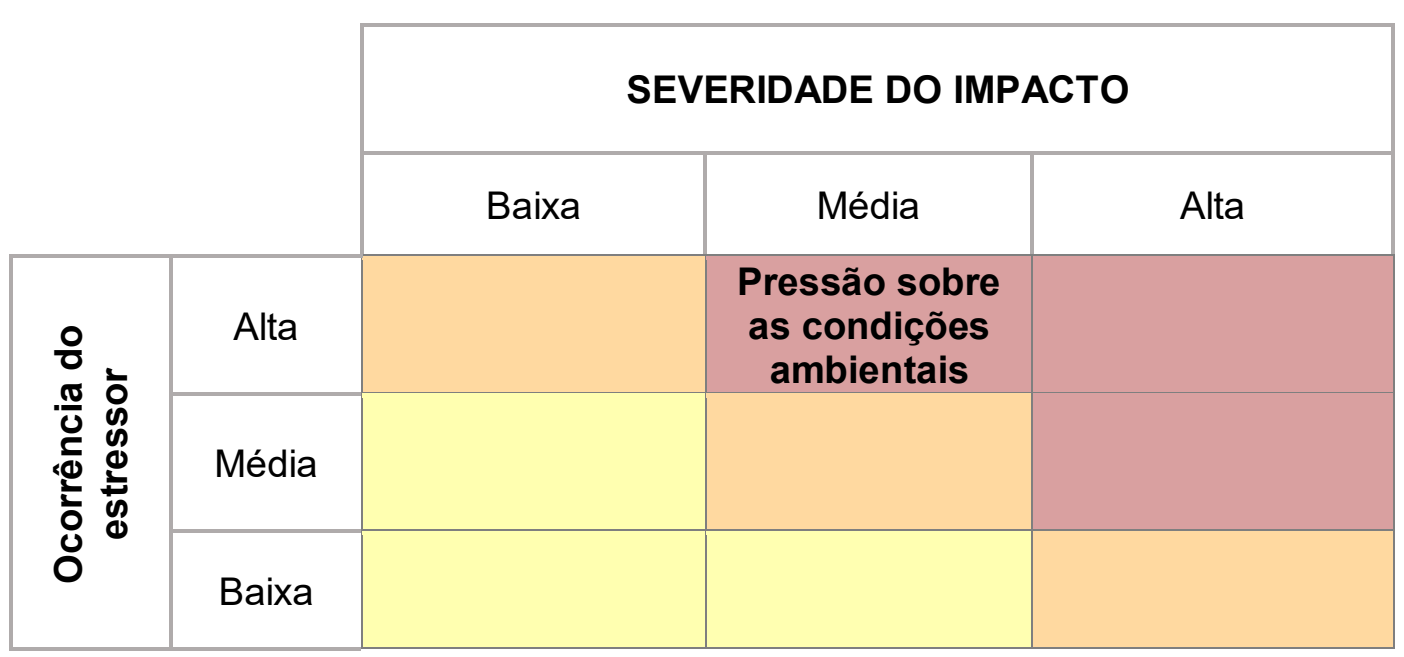

Risco

Aceitáveis

Toleráveis

Inaceitáveis

Portanto, o risco estimado para a quantidade e qualidade da água utilizada para abastecer Porto Nacional foi estimado como sendo "inaceitável" quanto ao estressor "pressão sobre as condições ambientais" sobre a Bacia do Córrego São João. Este nível é um alerta que demanda medidas de gestão imediatas, pelo menos para evitar que o risco se torne inaceitável. Idealmente, ações e programas de proteção dos mananciais, ou criação de UCs, deveriam ser empreendidas para reduzir o risco ao nível aceitável.

Com o Cadastro Ambiental Rural (CAR) e o PRAD (Plano de Áreas Degradadas), existe uma janela de oportunidade para recuperar parte do passivo ambiental, além de fornecer conhecimento para outras medidas de proteção.

\subsubsection{Estressor de água bruta (2): Demanda por água (pressão sobre a quantidade)}

Globalmente, a disponibilidade de água do Córrego São João é limitada pelo porte da bacia hidrográfica, enquanto a pressão por demanda de água na bacia é alta e com tendência de crescimento, sendo que o abastecimento público representa o uso preponderante na porção da bacia em estudo, conforme será apresentado. 


\subsubsection{Disponibilidade hídrica}

O decreto estadual $n^{\circ} 2.432$, de 6 de junho de 2005 regulamenta a outorga de direito de uso de recursos hídricos de que dispõe os artigos $8^{\circ}, 9^{\circ}$ e 10 da Lei Estadual 1.307/2002, a outorga do direito de uso de Recursos Hídricos é regulamentada por esse decreto estadual e incumbe ao Naturatins outorgar o direito de uso dos recursos hídricos, a outorga é condicionada à disponibilidade hídrica e às prioridades expressas no Plano Estadual de Recursos Hídricos.

O estudo das vazões nos cursos d'água tem finalidades diversas que dependem, essencialmente, do tipo das vazões estudadas. Enquanto as vazões máximas são importantes para o dimensionamento e operação de obras hidráulicas, como canais, barramentos, vertedores e comportas, as vazões médias e mínimas estão associadas à disponibilidade hídrica, informação fundamental para o projeto e gestão das múltiplas atividades que utilizam os recursos hídricos, seja por meio de captações, barramentos ou diluição de poluentes lançados nos cursos d'água (FAPTO, 2015).

A vazão foi definida conforme análise do Naturatins, que analisa a vazão de determinado curso de água interpolando para uma vazão de referência. Vazão de referência é aquela que representa a disponibilidade hídrica do curso de água, associada a uma probabilidade de ocorrência. Segundo a Resolução CONAMA 357/2005, é a "vazão do corpo hídrico utilizada como base para o processo de gestão, tendo em vista o uso múltiplo das águas e a necessária articulação das instâncias do Sistema Nacional de Meio Ambiente - SISNAMA e do Sistema Nacional de Gerenciamento de Recursos Hídricos - SINGRH".

No estado do Tocantins, a vazão de referência é a $Q_{90}$, ou seja, a vazão determinada a partir das observações em um posto fluviométrico em certo período de tempo (serie histórica), em que $90 \%$ daquele período as vazões foram iguais ou superiores a ela. Diz-se que a Q9o é a vazão com $90 \%$ de permanência no tempo, podendo ser extrapolado para outras seções do curso d'água, com base na área da bacia hidrográfica contribuinte e nas qualidades de chuvas da região (ANA, 2011).

A legislação estabelece percentuais sobre essa "vazão de referência", que representam os limites máximos de utilização da água na seção do rio ou reservatório, de modo a estabelecer as vazões mínimas que devem permanecer no corpo hídrico para atender a manutenção dos ecossistemas aquáticos e as 
exigências da biota. No estado do Tocantins, a vazão outorgável é correspondente a $75 \%$ da Q90.

Para determinar a Q90 do Córrego São João, a Naturatins utilizou uma série histórica de vazões utilizando a estação fluviométrica Porto Real que fica localizada nas proximidades do córrego São João (a jusante do ponto de captação). O resultado, apresentado no quadro 09, refere-se à vazão da foz do córrego São João.

QUADRO 9 - Dados das vazões mensais em $\mathrm{m}^{3} / \mathrm{s}$

\begin{tabular}{|l|l|}
\hline Meses & $\mathbf{Q}_{\mathbf{9 0}}\left(\mathbf{m}^{\mathbf{3}} / \mathbf{s}\right)$ \\
\hline Janeiro & 1,203 \\
\hline Fevereiro & 1,463 \\
\hline Março & 1,638 \\
\hline Abril & 1,306 \\
\hline Maio & 0,884 \\
\hline Junho & 0,680 \\
\hline Julho & 0,546 \\
\hline Agosto & 0,543 \\
\hline Setembro & 0,472 \\
\hline Outubro & 0,573 \\
\hline Novembro & 0,745 \\
\hline Dezembro & 1,039 \\
\hline
\end{tabular}

Fonte: Naturatins (2016)

Outra referência encontrada (relatório de diagnóstico fase A, do FAPTO, 2015) aponta uma estação fluviométrica (22350500) em Porto Nacional operada pela companhia de abastecimento Saneatins, com registro esporádico, localizada nas coordenadas latitude -1042'54,38” e longitude 48²2'16,84”, com apenas um registro de vazão de 2007, sem coordenadas, no córrego São João. Consta que a medição foi feita 100 metros a jusante do barramento, a disponibilidade hídrica é apresentado no quadro 09.

QUADRO 10 - Disponibilidade hídrica média $\left(\mathrm{m}^{3} / \mathrm{s}\right)$ na foz do Córrego São João

\begin{tabular}{|c|c|c|c|c|}
\hline \multicolumn{2}{|c|}{ Bacia } & \multicolumn{3}{c|}{ Disponibilidade hídrica média - Vazões médias $\mathbf{~ m}^{3} / \mathbf{s}$} \\
\hline Córrego São João Área útil $\left(\mathrm{km}^{2}\right)$ & Período atual & Período seco & Período chuvoso \\
\hline & 81,9 & 1,556 & 0,655 & 2,784 \\
\hline
\end{tabular}

Fonte: FAPTO (2015) 


\subsubsection{Demanda: Usos e usuários de água}

\section{Usuários regularizados}

Os dados referentes ao quantitativo de usuários e vazões outorgadas por finalidade de uso foram solicitados ao órgão competente (Naturatins - Gerência de Controle de Recursos Hídricos), mas o cadastro de usuários encontra-se em construção.

Pode-se observar que os registros (figura 32) compreendem o período de 2011 a 2016, perfazendo o quantitativo de nove DUls e oito atos administrativos de outorga na área total da bacia, tanto abaixo como acima do ponto de captação de abastecimento.

Os dados referentes às declarações de usos insignificantes não foram disponibilizados individualmente pelo setor responsável, apenas a figura que sinaliza os atos administrativos e outorgas de usos de recursos hídricos e usos insignificantes na bacia do Córrego São João.

A figura 32 apresenta espacialmente as distribuições das outorgas e declarações de uso insignificante (DUI) na bacia, indicando maior dispersão no baixo curso do córrego São João. 
FIGURA 32 - Outorgas e Declaração de Usos Insignificantes do direito de uso da água autorizados pelo Naturatins na bacia do Córrego São João

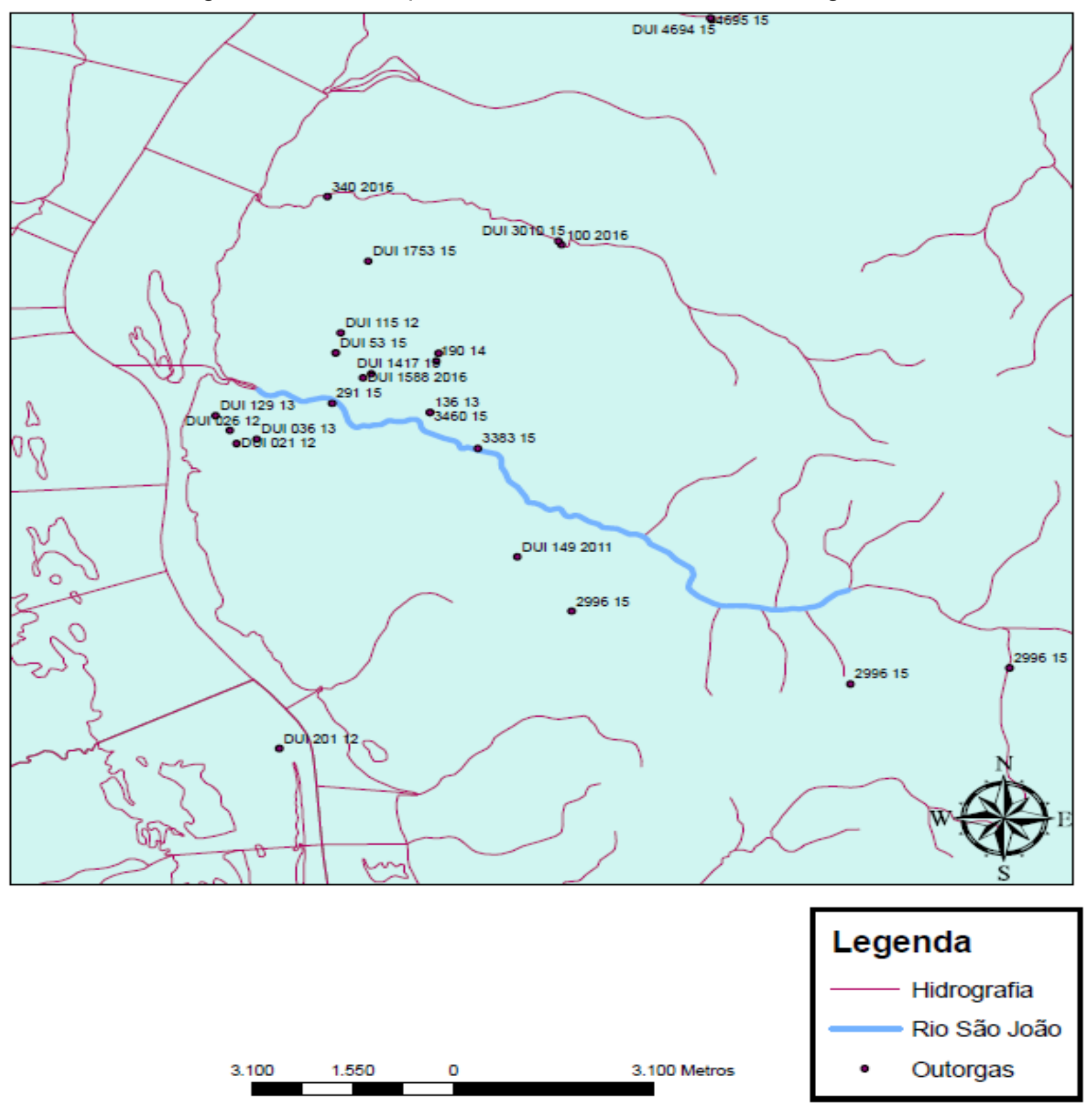

Fonte: NATURATINS (2016)

A outorga de abastecimento público encontra-se vencida atualmente, sem ato administrativo, os dados expostos foram disponibilizados oficialmente em junho de 2016 e março de 2017.

Os usuários outorgados na bacia do córrego São João, quadro 10, somam uma vazão de $650,75 \mathrm{~m}^{3} / \mathrm{h}$ ou $180,76 \mathrm{l} / \mathrm{s}$, sendo aproximadamente $94 \%$ para abastecimento público, $6 \%$ para serviços de obras no trecho a jusante do ponto de captação no córrego São João. 
QUADRO 11 - Quantitativo e vazão outorgada por finalidade de uso no Córrego São João

\begin{tabular}{|l|c|c|}
\hline Finalidade & Vazão $\left(\mathbf{m}^{3} / \mathrm{h}\right)$ & \multicolumn{2}{|l|}{$\begin{array}{l}\text { Percentual da } \\
\text { vazão outorgada } \\
\text { em relação ao total }\end{array}$} \\
\hline $\begin{array}{l}\text { Abastecimento } \\
\text { Público }\end{array}$ & $612 \mathrm{~m}^{3} / \mathrm{h}$ & $94 \%$ \\
\hline Obras Civis & $38,75 \mathrm{~m}^{3} / \mathrm{h}$ & $6 \%$ \\
\hline Irrigação & - & - \\
\hline Outros & - & - \\
\hline Total & $650,75 \mathrm{~m}^{3} / \mathrm{h}$ & 100 \\
\hline
\end{tabular}

Fonte: Naturatins (2016)

O sistema de declarações de uso insignificante e dos demais usos realizados na bacia está em construção, situação que dificulta o conhecimento com exatidão a realidade do crescimento das demandas hídricas, pois possivelmente os demais usos na Bacia, a montante do ponto de captação devem ser em grande parte usos insignificantes.

\section{Estimativa de demandas}

A base de dados do instrumento de outorga do direito de uso dos recursos hídricos, principal fonte de informações sobre o consumo de água, ainda não é representativo do cenário real de demandas no estado do Tocantins, porém foi possível estimar as demandas com base nos dados censitários do IBGE, associados aos principais usos de água na bacia hidrográfica do córrego São João (FAPTO, 2015).

Foram utilizados dados secundários do IBGE para estimativas de consumo no futuro, nos três horizontes da bacia: 5 anos (curto prazo), 10 anos (médio prazo) e 20 anos (longo prazo). Destacando-se a incerteza na transformação dos dados secundários em demanda hídrica, embora tenha utilizado os dados do IBGE (FAPTO, 2015).

Apesar do planejamento da bacia ser orientado à garantia dos usos múltiplos dos recursos hídricos, não é possível estimar as demandas futuras para todos os usos ou atividades que demandam água. Dessa forma, uma atenção maior foi dada aos usos prioritários na bacia hidrográfica, conforme identificados nos estudos do diagnóstico: a) abastecimento público; b) dessedentação animal; e c) agricultura irrigada. Em cada uso, foram utilizadas projeções correspondentes às diferentes séries históricas do IBGE, assim: 
- Abastecimento público: séries históricas de população rural e urbana de 1990, 2000, 2010, 2015;

- Dessedentação animal: séries históricas de número de cabeças de rebanhos de 1990 a 2015; e

- Agricultura irrigada: séries históricas de áreas plantadas de culturas comerciais de 1991 a 2015.

O estudo destaca que, apesar da disponibilidade dos dados do IBGE, a transformação de dados secundários em demanda hídrica é cercada por incertezas (FAPTO, 2015). Enquanto os dados de população apresentam comportamentos de modelagem relativamente simples, as séries históricas de rebanhos e áreas plantadas sofrem grandes variações ao longo dos anos, uma vez que o comportamento não sofre influência apenas do tempo. Além da dificuldade de ajustamento estatístico das tendências do passado, também é incerto supor que no futuro seguiremos com as tendências do passado (FAPTO, 2015).

Outro ponto que merece destaque é a transformação dessas informações (população, rebanhos e áreas plantadas) em vazões demandadas. Embora existam tabelas de consumo médio diário na literatura é preciso transformar o consumo diário em vazão em m3/s, a fim de permitir o cálculo do balanço hídrico entre as disponibilidades e demandas, produto mais importante no diagnóstico e prognóstico da bacia. Nesse aspecto, são atribuídas horas de consumo, tanto para o uso no abastecimento (20 h), na dessedentação animal (4 horas) e na agricultura irrigada (8 horas). Todas as estimativas de consumo foram processadas no contexto das subbacias hidrográficas, não sendo possível localizar as demandas em escalas menores, por exemplo: para verificar conflitos a nível da hidrografia (FAPTO, 2015).

Com base nas estimativas de população total nas sub-bacias, foram calculadas as demandas de abastecimento público, dessedentação de animais e agricultura irrigada no horizonte de 20 anos, apresentadas no quadro 11. 
QUADRO 12 - Demandas hídricas e evolução da demanda (abastecimento público, dessedentação de animais e agricultura irrigada) na bacia hidrográfica do Córrego São João

\begin{tabular}{|c|c|c|c|c|c|c|c|}
\hline Tipos de Uso & $\mathbf{2 0 1 5}$ & $\mathbf{2 0 2 0}$ & $\mathbf{\%}$ & $\mathbf{2 0 2 5}$ & $\mathbf{\%}$ & $\mathbf{2 0 3 5}$ & $\mathbf{\%}$ \\
\hline $\begin{array}{c}\text { Abastecimento } \\
\text { Público }\end{array}$ & 126 & 131 & $4 \%$ & 137 & $9 \%$ & 149 & $19 \%$ \\
\hline $\begin{array}{c}\text { Dessedentação } \\
\text { Animal }\end{array}$ & 7 & 10 & $29 \%$ & 10 & $39 \%$ & 12 & $62 \%$ \\
\hline Agricultura & 30 & 33 & $9 \%$ & 41 & $36 \%$ & 58 & $90 \%$ \\
\hline
\end{tabular}

Fonte: FAPTO, 2006

No Plano da Bacia Hidrográfica do Entorno do Lago (FAPTO, 2015), é apresentado um resumo das demandas através de um esquema que resume outras características da Bacia, na figura 33.

FIGURA 33 - Síntese da Bacia do Córrego São João

\section{Sub-bacia do Córrego São João}
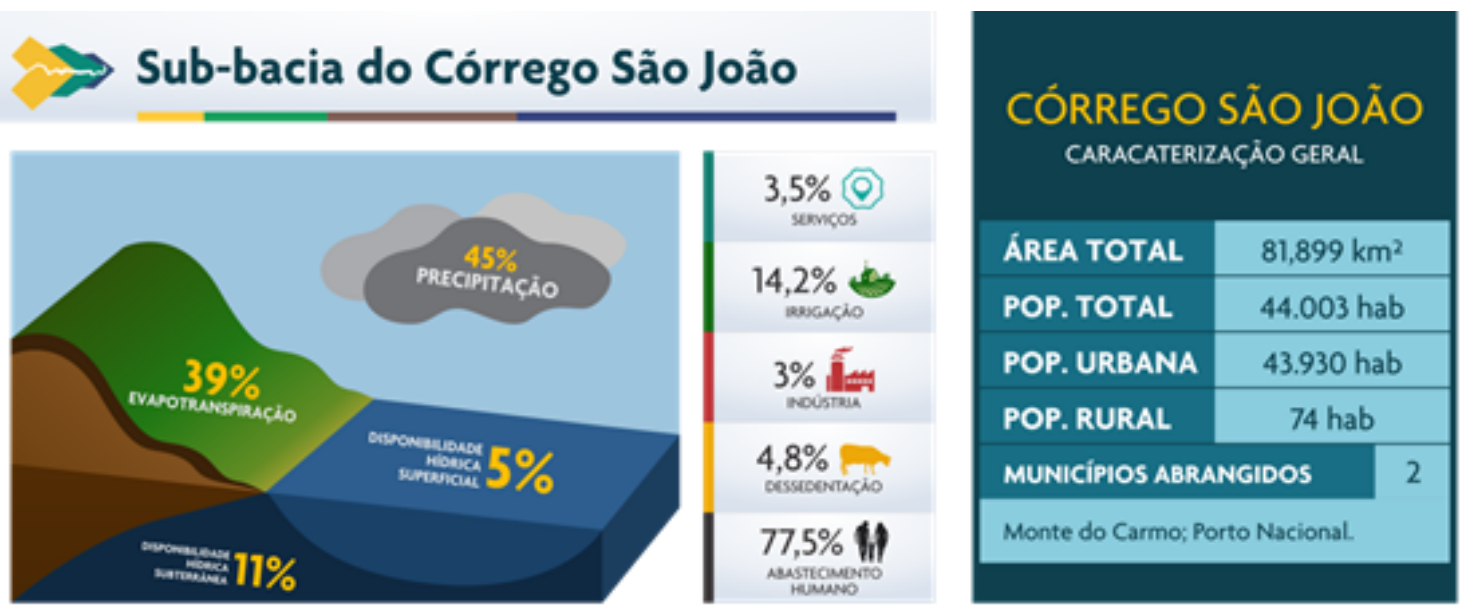

Fonte: FAPTO (2015)

Demanda futura da sede municipal: Plano Municipal de Água e Esgoto

Outra fonte de estimativa das demandas futuras de abastecimento água é o Plano Municipal de Água e Esgoto de Porto Nacional. Nele, é apontada a evolução populacional da sede municipal, de acordo com IBGE, exposto na figura 34 . 
FIGURA 34 - População censitária de Porto Nacional (Sede) - Censos IBGE

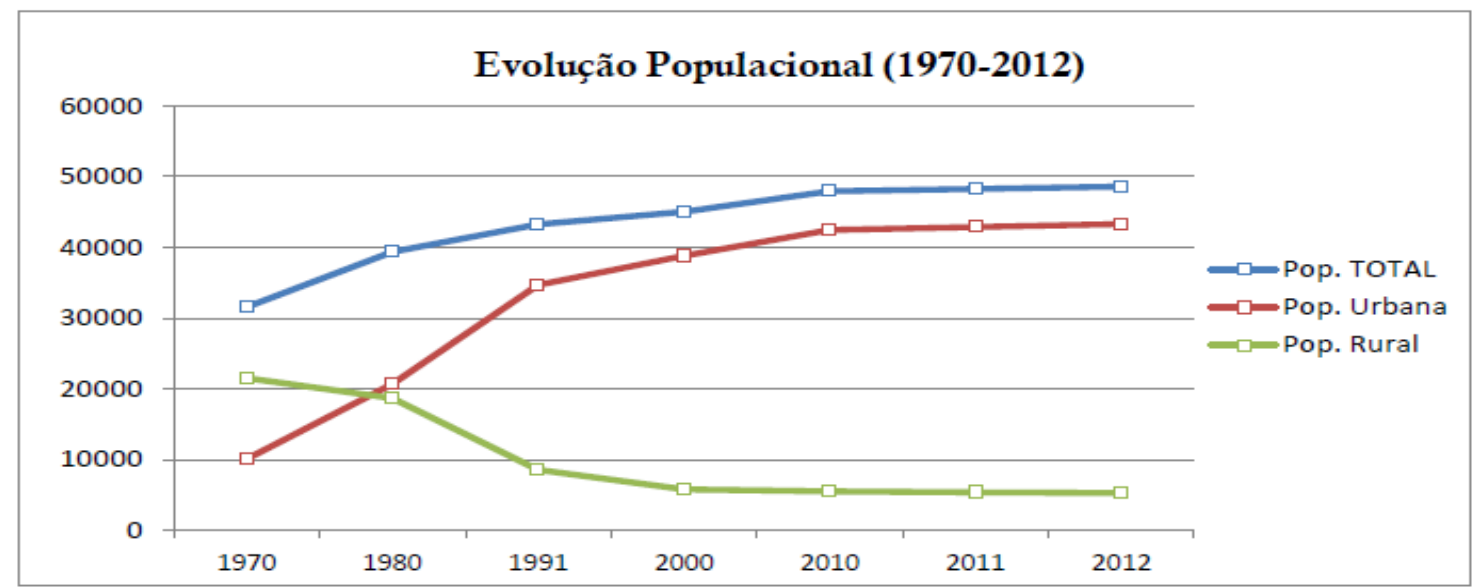

Fonte: PMAE, 2013

Conforme PMAE (2013), as projeções populacionais (figura 35) para o município de Porto Nacional - TO foram realizadas a partir do uso dos seguintes métodos: a) projeções elaboradas por meio do método das componentes; b) calibragens segundo o método AIBI (Apportionment Method); e c) aplicação de ajustes por meio de um terceiro procedimento metodológico para considerar os cenários de emprego. Nesse sentido, são considerados três cenários: um cenário tendencial, sem os investimentos produtivos (cenário 1), um cenário alternativo com parte dos investimentos previstos e confirmados para a região (cenário 2) e um cenário com todos os investimentos confirmados (cenário 3).

FIGURA 35 - Projeção populacional - Porto Nacional - TO - 2013/2042

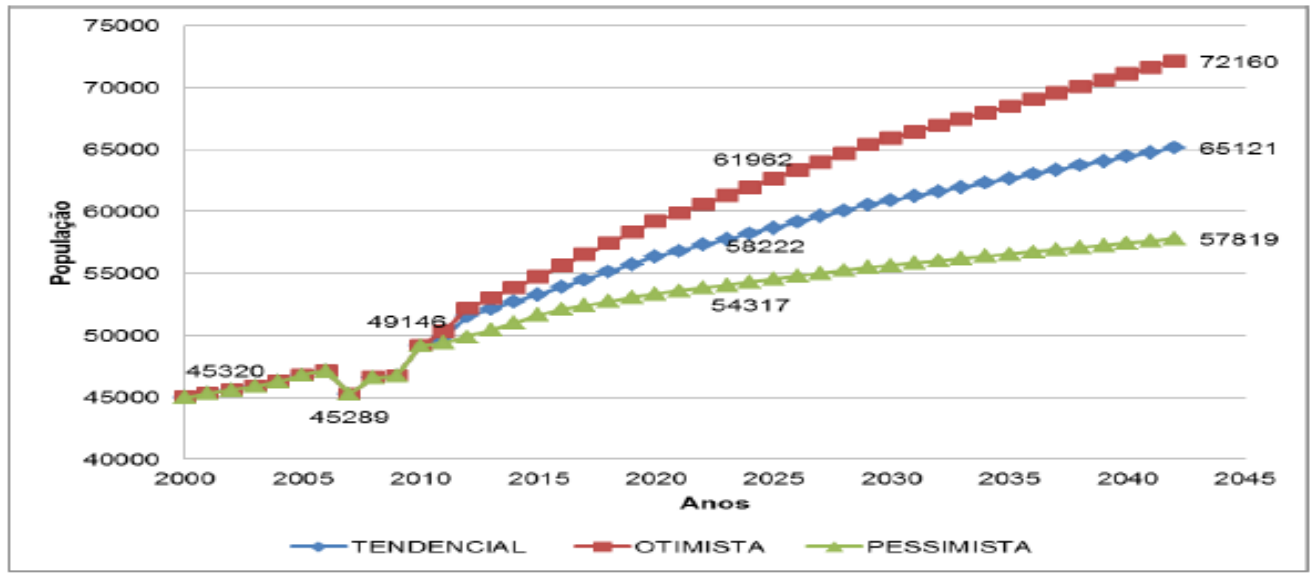

Fonte: IBGE, Projeções e PMAE 2013 
Observa-se uma tendência média de crescimento de aproximadamente 5\% da população total de Porto Nacional a cada 5 anos, considerado o primeiro e último ano, este crescimento evidencia um aumento de demanda de uso da água para abastecimento urbano, visto como prioridade preconizada em lei, porém o crescimento populacional interfere no aumento da demanda para outras atividades requeridas por essa população.

QUADRO 13 - Demanda de água de Porto Nacional - Sede

\begin{tabular}{|c|c|c|c|c|}
\hline \multirow[b]{2}{*}{ ANO } & \multicolumn{2}{|c|}{ POPULACCĀO } & \multirow{2}{*}{$\begin{array}{c}\text { ÍNDICE DE } \\
\text { ATENDIMENTO } \\
\text { TOTAL }\end{array}$} & \multirow{2}{*}{$\begin{array}{l}\text { POPULAÇĀO } \\
\text { ATENDIDA } \\
\text { (hab) }\end{array}$} \\
\hline & $\begin{array}{c}\text { TOTAL } \\
\text { (hab) }\end{array}$ & $\begin{array}{c}\text { URBANA } \\
\text { (hab) }\end{array}$ & & \\
\hline 2012 & 49.105 & 43.208 & $99 \%$ & 42.776 \\
\hline 2013 & 49.663 & 43.699 & $99 \%$ & 43.262 \\
\hline 2017 & 51.960 & 45.720 & $99 \%$ & 45.263 \\
\hline 2022 & 56.705 & 49.895 & $99 \%$ & 49.396 \\
\hline 2027 & 59.006 & 51.920 & $99 \%$ & 51.401 \\
\hline 2029 & 59.927 & 52.730 & $99 \%$ & 52.202 \\
\hline 2032 & 63.324 & 55.719 & $99 \%$ & 55.162 \\
\hline 2037 & 65.133 & 57.310 & $99 \%$ & 56.737 \\
\hline 2042 & 69.524 & 61.174 & $99 \%$ & 60.562 \\
\hline
\end{tabular}

Fonte: PMAE, 2013

Segundo o Plano de Saneamento do Município de Porto Nacional, elaborado em 2013, a demanda de água, a projeção da produção e a projeção resultante da população são indicadas nos quadros 13 e 14. As perdas na distribuição da água apontadas no plano municipal de água e esgoto são graves: em 2012 quase a metade da água captada era perdida. Os dados de redução de perdas nos anos de 2013 a 2016 não foram atualizadas e disponibilizadas pela Companhia de Saneamento, mas dificilmente uma companhia de água consegue reduzir tanto em tão pouco tempo, mesmo com um programa robusto de redução de perdas.

QUADRO 14 - Consumo percapita e perdas da sede municipal de Porto Nacional, em 2012 e estimadas até 2042

\begin{tabular}{|c|c|c|c|c|c|c|c|c|}
\hline \multirow{2}{*}{ ANO } & \multicolumn{4}{|c|}{ CONSUMO - 24h } & \multicolumn{3}{c|}{ PERDA } & \multicolumn{3}{c|}{ PRODUÇÃO - 21h } \\
& PERCAPITA & MÉDIO & \multicolumn{2}{|c|}{ MÁX. DIA } & MÉDIA & PERCAPITA & MÉDIA & MÁX. DIA \\
\cline { 2 - 9 } & (I/hab.dia) & $\mathbf{( I / s )}$ & $\mathbf{( m 3 / h )}$ & $\mathbf{( I / s )}$ & TOTAL & (I/hab.dia) & (I/s) & (I/s) \\
\hline 2012 & 139 & 69,46 & 83,35 & 83,35 & $46 \%$ & 258 & 146,04 & 175,24 \\
\hline \hline 2013 & 143 & 72,35 & 86,82 & 86,82 & $44 \%$ & 254 & 145,58 & 174,70 \\
2017 & 160 & 84,52 & 101,42 & 101,42 & $34 \%$ & 242 & 145,10 & 174,12 \\
\hline 2022 & 160 & 92,24 & 110,68 & 110,68 & $22 \%$ & 205 & 133,79 & 160,55 \\
2027 & 160 & 95,98 & 115,18 & 115,18 & $21 \%$ & 202 & 137,46 & 164,95 \\
2029 & 160 & 97,48 & 116,97 & 116,97 & $21 \%$ & 201 & 138,90 & 166,68 \\
\hline 2032 & 160 & 103,00 & 123,60 & 123,60 & $20 \%$ & 200 & 145,68 & 174,81 \\
2037 & 160 & 105,95 & 127,13 & 127,13 & $20 \%$ & 200 & 149,84 & 179,80 \\
2042 & 160 & 113,09 & 135,71 & 135,71 & $20 \%$ & 200 & 159,94 & 191,93 \\
\hline
\end{tabular}


QUADRO 15 - Demanda de água de Porto Nacional - Sede

\begin{tabular}{|c|c|c|c|}
\hline \multirow{2}{*}{\multicolumn{2}{|c|}{ ANO }} & \multicolumn{2}{|c|}{ PORTO NACIONAL - SEDE } \\
\hline & & \multirow{2}{*}{$\frac{\text { POP. TOTAL }}{46.836}$} & \multirow{2}{*}{$\frac{\text { POP. URBANA }}{41.211}$} \\
\hline CENSO & 2010 & & \\
\hline & 2011 & 47.527 & 41.819 \\
\hline & 2012 & 49.105 & 43.208 \\
\hline $1^{\circ}$ ano & 2013 & 49.663 & 43.699 \\
\hline $2^{\circ}$ ano & 2014 & 50.228 & 44.196 \\
\hline $3^{\circ}$ ano & 2015 & 50.799 & 44.698 \\
\hline $4^{\circ}$ ano & 2016 & 51.376 & 45.206 \\
\hline $5^{\circ}$ ano & 2017 & 51.960 & 45.720 \\
\hline $6^{\circ}$ ano & 2018 & 52.544 & 46.234 \\
\hline $7^{\circ}$ ano & 2019 & 53.128 & 46.748 \\
\hline $8^{\circ}$ ano & 2020 & 55.785 & 49.085 \\
\hline $9^{\circ}$ ano & 2021 & 56.245 & 49.490 \\
\hline $10^{\circ}$ ano & 2022 & 56.705 & 49.895 \\
\hline $11^{\circ}$ ano & 2023 & 57.165 & 50.300 \\
\hline $12^{\circ}$ ano & 2024 & 57.626 & 50.705 \\
\hline $13^{\circ}$ ano & 2025 & 58.086 & 51.110 \\
\hline
\end{tabular}

De acordo com o Plano (tabelas 5, 6 e 7), a demanda adicional para o abastecimento de água da população futura da sede municipal de Porto Nacional seria de aproximadamente $90,51 \mathrm{l} / \mathrm{s}$ ou $40 \mathrm{l} / \mathrm{hab}$.dia.

\subsubsection{Balanço hídrico}

O Plano da Bacia Hidrográfica do Entorno do Lago (FAPTO, 2016) fez o cálculo do balanço hídrico para avaliar o comprometimento da disponibilidade hídrica da Bacia do Córrego São João. O quadro 15 resume os resultados do balanço, apresentando: i) as vazões médias (Qmld) e a vazão de referência (Q90), ii) as vazões demandadas estimadas e outorgadas e iii) o comprometimento das demandas atuais em relação a disponibilidade hídrica média e de referência da bacia. 
QUADRO 16 - Balanço hídrico entre disponibilidades e demandas outorgadas e estimadas, e comprometimento (\%) da disponibilidade hídrica média e de referência na bacia.

\begin{tabular}{|c|c|c|c|c|c|c|c|c|c|}
\hline \multirow{2}{*}{ Id } & \multirow{2}{*}{ Sub-Bacia } & \multirow{2}{*}{$\operatorname{Qmld}\left(\mathrm{m}^{3} / \mathrm{s}\right)$} & \multirow{2}{*}{$\mathbf{Q}_{90}\left(\mathbf{m}^{3} / \mathrm{s}\right)$} & \multirow{2}{*}{ Estimado $\left(\mathrm{m}^{3 / \mathrm{s}}\right)$} & \multirow{2}{*}{ Outorgado $\left(\mathrm{m}^{3} / \mathrm{s}\right)$} & \multicolumn{2}{|c|}{ Estimado } & \multicolumn{2}{|c|}{ Outorgado } \\
\hline & & & & & & Qmid & $Q_{90}$ & Qmld & $Q_{90}$ \\
\hline 1 & Córrego Comprido & 0,884 & 0,093 & 0,1652 & 0,1781 & $18,68 \%$ & $177,46 \%$ & $20,14 \%$ & $191,36 \%$ \\
\hline 2 & Ribeirão Água Fria & 1,654 & 0,174 & 0,2273 & 0,1983 & $13,74 \%$ & $130,57 \%$ & $11,99 \%$ & $113,89 \%$ \\
\hline 3 & Ribeirão Taquaruçu Grande & 7,538 & 0,793 & 0,9076 & 0,7646 & $12,04 \%$ & $114,39 \%$ & $10,14 \%$ & $96,37 \%$ \\
\hline 4 & Ribeirão Conceição & 6,636 & 0,699 & 0,1471 & 0,1053 & $2,22 \%$ & $21,06 \%$ & $1,59 \%$ & $15,07 \%$ \\
\hline 5 & Córrego São João & 1,556 & 0,164 & 0,1581 & 0,0056 & $10,16 \%$ & $96,52 \%$ & $0,36 \%$ & $3,42 \%$ \\
\hline 6 & Rio Crixás & 62,803 & 6,611 & 1,4604 & 0,1921 & $2,33 \%$ & $22,09 \%$ & $0,31 \%$ & $2,91 \%$ \\
\hline 7 & Rio Água Suja & 17,858 & 1,880 & 0,4079 & 0,0510 & $2,28 \%$ & $21,70 \%$ & $0,29 \%$ & $2,71 \%$ \\
\hline 8 & Ribeirão São João & 5,291 & 0,557 & 0,1153 & 0,0072 & $2,18 \%$ & $20,70 \%$ & $0,14 \%$ & $1,29 \%$ \\
\hline 9 & Ribeirão do Carmo & 7,253 & 0,763 & 0,1776 & 0,0080 & $2,45 \%$ & $23,27 \%$ & $0,11 \%$ & $1,05 \%$ \\
\hline 10 & Rio Areias & 44,236 & 4,656 & 0,9059 & 0,0284 & $2,05 \%$ & $19,45 \%$ & $0,06 \%$ & $0,61 \%$ \\
\hline 11 & Rio Matança & 6,701 & 0,705 & 0,1444 & 0,0030 & $2,15 \%$ & $20,47 \%$ & $0,04 \%$ & $0,43 \%$ \\
\hline 12 & Ribeirão dos Mangues & 48,772 & 5,134 & 1,2697 & 0,0207 & $2,60 \%$ & $24,73 \%$ & $0,04 \%$ & $0,40 \%$ \\
\hline 13 & Córrego Santa Luzia & 23,622 & 2,487 & 0,6399 & 0,0006 & $2,71 \%$ & $25,73 \%$ & $0,00 \%$ & $0,02 \%$ \\
\hline 14 & Ribeirão Lajeado & 12,901 & 1,358 & 0,3263 & 0,0003 & $2,53 \%$ & $24,03 \%$ & $0,00 \%$ & $0,02 \%$ \\
\hline 15 & Rio Formiga & 34,723 & 3,655 & 0,6450 & 0,0000 & $1,86 \%$ & $17,65 \%$ & $0,00 \%$ & $0,00 \%$ \\
\hline
\end{tabular}

Fonte: FAPTO, 2016.

Considerando-se as vazões demandadas estimadas, que certamente é mais realista do que a vazão outorgada, foi evidenciada uma situação crítica na Bacia, com pelo menos $96 \%$ de comprometimento da vazão outorgável (os problemas dos dados são evidenciados inclusive pelo conflito de informações: o comprometimento da vazão outorgável é apontado como sendo de 96\% e 107\%).

Ressalte-se que o diagnóstico do Plano constatou também situação de risco elevado de conflitos entre usuários de água nas bacias urbanas dos municípios de Palmas (Água Fria, Brejo Comprido e Taquaruçu Grande), além de Porto Nacional (Córrego São João). Nessas bacias, os indicadores demonstram que já em 2015, são utilizadas vazões superiores à vazão outorgável, isto é, maiores que $75 \%$ da Q90 (ver quadro acima).

Comparando-se os valores de vazão mínima de referência (Q90) e as vazões totais demandadas nas sub-bacias, somando-se ainda as vazões outorgadas para os demais usos não estimados com base nos dados secundários do IBGE, elaborou-se o balanço hídrico nas sub-bacias levando-se em conta os horizontes de curto, médio e longo prazo do Plano de Bacia, ou seja, para o ano de 2020, 2025 e 2035, apresentado no quadro 16. 
QUADRO 17 - Balanço hídrico atual e projetado entre as disponibilidades e as demandas hídricas

\begin{tabular}{|c|c|c|c|c|c|c|c|c|c|c|c|}
\hline \multirow{3}{*}{ Sub-Bacia } & \multicolumn{2}{|c|}{$\begin{array}{l}\text { Disponibilidade } \\
\text { Hídrica }\end{array}$} & \multirow{3}{*}{\multicolumn{3}{|c|}{ 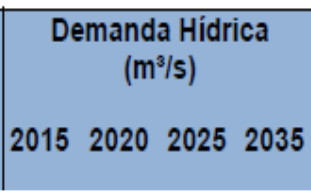 }} & \multicolumn{6}{|c|}{$\begin{array}{c}\text { Balanço Hidrico } \\
\text { Disponibilidade X Demanda (\%) }\end{array}$} \\
\hline & $Q_{\text {mld }}$ & $Q_{90}$ & & & & 2015 & 20 & 20 & & 025 & 2035 \\
\hline & $\left(\mathrm{m}^{3} / \mathrm{s}\right)$ & $\left(\mathrm{m}^{3} / \mathrm{s}\right)$ & & & & $Q_{\text {mld }} Q_{90}$ & $Q_{\text {mld }}$ & $Q_{90}$ & $Q_{\text {mld }}$ & $Q_{90}$ & $Q_{\text {mld }} Q_{90}$ \\
\hline Córrego São João & 1,556 & 0,164 & $0,18 \quad 0,19$ & 0,20 & 0,24 & $11 \quad 107$ & 12 & 113 & 13 & 123 & $\begin{array}{ll}15 & 144\end{array}$ \\
\hline
\end{tabular}

Fonte: FAPTO, 2016.

Como evidenciado acima, o cenário atual tende a piorar, caso não sejam tomadas medidas de controle do uso da água, de incentivo ao uso racional para evitar conflitos entre o abastecimento público e os usuários de montante. Ressaltese que a prioridade, por lei, é o abastecimento humano e a dessedentação de animais.

\subsubsection{Ações de gestão em execução com interferência na demanda por água}

Pode-se dizer que o gerenciamento integrado de recursos hídricos na Bacia ainda é embrionário, pois nem mesmo os usos de água são controlados. $A$ bacia do córrego São João não possui cadastro de usuários de recursos hídricos. Segundo o comitê da Bacia Hidrográfica do Lago de Palmas, após elaboração do manual de outorga será fomentado o cadastro de usuários para atualizar o sistema de informação de recursos hídricos do Estado do Tocantins.

É fundamental a realização de uma campanha de cadastro de usuários da bacia para a alimentação do banco de dados para a operação do sistema de informações de recursos hídricos. Essa ação está programada para ocorrer em 2017 e 2018 pelo comitê de bacia hidrográfica do Entorno do Lago, de acordo com plano de ações divulgado pelo comitê em consulta pública realizada no dia 26/10/16 no auditório do Palácio Araguaia na cidade de Palmas-TO.

Há outras atividades agropecuárias realizadas na bacia sem registros ambientais disponibilizados pelo órgão competente. Em várias visitas de campo, a autora registrou atividades de piscicultura, plantações de hortaliças (maxixe, jiló e cebolinha), represas para lazer, criação de galinhas, porco e gado.

Considerando apenas a diretoria de recursos hídricos do Naturatins, especificamente a coordenação de outorga pelo uso da água, realmente constata-se 
uma deficiência de pessoal e estrutura física para assumir todas as atividades de sua competência. Como esse órgão responde também pelo licenciamento ambiental, o que se refere à gestão dos recursos hídricos, invariavelmente não é a primeira prioridade, já que o setor de licenciamento e também o de fiscalização são mais priorizados e estão mais visados pela opinião pública e têm que dar respostas mais imediatas (FAPTO, 2015).

Segundo a FAPTO (2016), as ações de monitoramento de vazões, precipitações, sedimentos, qualidade da água, águas subterrâneas, áreas de preservação permanente (APPs), e também da expansão urbana e da fronteira agrícola na bacia estão previstas para ocorrerem no ano de 2017 , dificilmente poderá se concretizar ainda neste ano, tendo em vista que a $18^{a}$ reunião do comitê da bacia ocorreu no dia 23/05/2017 onde foram constituídas as câmaras técnicas do plano da bacia, de outorga e educação ambiental.

Em relação ao uso da água e possíveis conflitos pelo uso da água, é a outorga que determinará se há água em quantidade e qualidade conforme o solicitado pelo usuário. Outras questões como a viabilidade ambiental do empreendimento são verificadas pelo licenciamento (FAPTO, 2016).

Entende-se aqui que o usuário deverá sempre contatar uma série de órgãos e instâncias para a implantação de seu empreendimento, o que pode levar à instalação incorreta do mesmo, oque pode levar a um uso incorreto dos recursos hídricos. Torna-se fundamental a organização de uma ampla campanha de regularização do uso de recursos hídricos em todo o Estado do Tocantins (FAPTO, 2016).

Vergara (2007) ressalta que a partir do momento em que a lei 9433/97 define que a gestão dos recursos hídricos deve ser participativa, as soluções devem ter análises por um grupo de agentes diversificados, com os mais variados valores e interesses. No caso de decisões estratégicas associadas ao sistema de gestão de recursos hídricos, em que são significativas as incertezas e é limitada a governabilidade dos gestores de recursos hídricos sobre as variáveis determinantes da evolução do sistema, impõe-se, naturalmente, a escolha de uma lógica construtivista para uma abordagem de apoio à decisão. 


\section{$\underline{\text { 5.1.2.5 Análise do risco }}$}

Com base na avaliação quanto à "demanda por água" na Bacia, apresentado na figura 36, foi estimado o risco de insuficiência de quantidade de água, no ponto de captação da ETA 02:

- Conforme evidenciado pelos estudos disponíveis, sobretudo o Plano da Bacia Hidrográfica do Entorno do Lago, a ocorrência do estressor é significativa porque há indícios - através de estimativa - de que a demanda por água está próxima ou já superou o limite outorgável; em 2015, são utilizadas vazões maiores que às vazões outorgáveis, ou seja, maiores de $75 \%$ da Q90. No futuro, este estressor tende a pressionar ainda mais a bacia, por conta do crescimento populacional e da expansão de atividades na parte montante da bacia. Além do mais, não se conhece os usos e usuários na área a montante do ponto de captação, porque o cadastro de usuários da bacia é incompleto e desatualizado.

- O impacto pode ser avaliado como sendo de média severidade, já que, em tese, superado o limite da vazão outorgável, o sistema de abastecimento urbano, que se situa a jusante da maior parte dos demais usos múltiplos, pode ter problemas de disponibilidade de água necessária para o abastecimento urbano nas estações secas. 
FIGURA 36 - Matriz de risco associado à demanda por água (pressão sobre a quantidade)

\begin{tabular}{|c|c|c|c|c|}
\hline & & \multicolumn{3}{|c|}{ Severidade do impacto } \\
\hline & & Baixa & Média & Alta \\
\hline \multirow{3}{*}{ 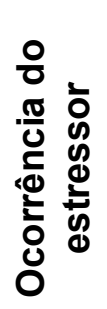 } & Alta & & $\begin{array}{l}\text { Demanda } \\
\text { por água }\end{array}$ & \\
\hline & Média & & & \\
\hline & Baixa & & & \\
\hline
\end{tabular}

\section{Risco \\ Aceitáveis \\ Toleráveis \\ Inaceitáveis}

Portanto, o risco foi estimado como sendo "inaceitável" quanto ao estressor "demanda por água (pressão sobre a quantidade de água)" sobre a Bacia do Córrego São João, no ponto de captação da ETA 02.

Como se trata do único manancial de abastecimento público do município de Porto Nacional, faz-se realmente necessário adotar medidas urgentes de controle do uso da água, atual e futuro, para evitar problemas futuros de desabastecimento relacionados à água bruta. Nesse quesito, as pesquisas de campo, de 2015 a 2017, evidenciaram uma expansão de atividades consumidoras de água a montante do ponto e captação, o que á altamente preocupante e configura um cenário de conflitos de uso.

Outro aspecto importante foi o alto volume de perdas do sistema de abastecimento, que, se forem reduzidas, aumentará a segurança hídrica do Município e diminuirá a pressão sobre o manancial.

\subsubsection{Estressor da água bruta (3): carga poluidora (pressão sobre a qualidade das águas)}

Não foi possível efetuar a análise deste estressor segundo metodologias comumente adotadas tais como o Índice de Conformidade do Enquadramento - ICE 
(ANA, 2012; Melo (2016). Tal aplicação exige uma série de dados sobre qualidade de água que geralmente não existem ou não estão disponíveis em muitas bacias, sobretudos aquelas de pequeno porte como a Bacia do Córrrego São João.

De fato, as informações sobre a qualidade das águas do Córrego São João são raras e pontuais, tendo sido identificado um estudo de um grupo de pesquisadores universitários da UFT e IFTO (Carvalho et al., 2016) que fizeram uma campanha ao longo do Córrego São João, de fevereiro de 2014 a fevereiro de 2015.

O Plano da Bacia Hidrográfica do Entorno do Lago utilizou as informações da Companhia de Abastecimento de Água de Porto Nacional, indicadas adiante, por essa razão, este estressor será avaliado de maneira qualitativa, buscando, de um lado, a identificação de fontes poluidoras (ocorrência do estressor) e, de outro lado, a avaliação disponível da qualidade das águas da Bacia que é o indicador do impacto das diferentes fontes poluidoras, pontuais e difusas, sobre os recursos hídricos.

\subsubsection{Fontes pontuais e difusas de poluição}

Das fontes potenciais de poluição, destacam-se duas delas: lançamento de esgoto doméstico e poluentes difusos de origem agrícola.

\section{Poluição doméstica/urbana}

Araújo et al. (2014), ao realizarem um diagnóstico preliminar de impactos ambientais no trecho urbano do Córrego São João, em 2009, identificaram modificações ambientais significativas na foz do córrego São João (resíduos sólidos, remoção da mata ciliar, erosão e aporte de esgoto), relacionadas à área urbana da sede de Porto Nacional.

De acordo com o PMAE (2013), nas residências situadas na sede de Porto Nacional o sistema de coleta de esgoto atende atualmente $61 \%$ da população urbana, percentual que já foi superior no período recente, porém foi reduzido devido à aprovação de loteamentos desprovidos de rede de esgotamento sanitário. Do esgoto coletado, o Plano aponta que a sua totalidade (100\%) é tratado.

É importante ressaltar que estes problemas não impactam a água captada para o abastecimento de Porto Nacional, pois o ponto de captação se situa a 
montante da área urbana. No entanto, evidenciou-se que a expansão urbana se aproxima da área da barragem; caso não haja um planejamento e controle, esta pode ser mais um estressor para a segurança hídrica do Município.

Por outro lado, a parte montante da Bacia é ocupada em grande parte pelo uso agropecuário, conforme indicado a seguir.

\section{$\underline{\text { Poluição difusa de origem rural }}$}

$\mathrm{Na}$ busca de identificação de potenciais fontes poluidoras, foi feita uma pesquisa junto à Naturatins para obter dados de licenciamento de atividades econômicas de porte na parte alta e média da Bacia. Foram obtidas informações recentes, resultado de uma incursão fiscalizadora para apurar denúncias de contaminação por agrotóxicos no Córrego São João, entre 30 de janeiro e 3 de fevereiro de 2017, justamente quando ocorre um grande uso de agrotóxicos na lavoura (Naturatins e Adapec, 2017).

Dentre as propriedades vistoriadas, 3 delas se situam a montante da captação, na margem esquerda do Córrego São João, e são licenciadas pela Naturatins (Tabela 5).

TABELA 5 - Empreendimentos rurais licenciados a montante do ponto de captação

\begin{tabular}{l|c|c|c|c|c}
\hline MUNICÍPIO & PROPRIETÁRIO & ARRENDATÁRIO & LATITUDE & LONGITUDE & $\begin{array}{c}\text { SOJA } \\
\text { Área } \\
\text { (ha) }\end{array}$ \\
\hline Porto Nacional & & A & $10^{\circ} 45^{\prime} 36.9^{\prime \prime}$ & $48^{\circ} 20^{\prime} 59.4^{\prime \prime}$ & 290 \\
\hline Porto Nacional & B & & $10^{\circ} 44^{\prime} 29.2^{\prime \prime}$ & $48^{\circ} 19^{\prime} 44.4^{\prime \prime}$ & 140 \\
\hline Porto Nacional & C & & $10^{\circ} 44^{\prime} 35.1^{\prime \prime}$ & $48^{\circ} 21^{\prime} 02.2^{\prime \prime}$ & 320 \\
\hline TOTAL & \multicolumn{3}{|c}{} & & \\
\hline
\end{tabular}

Fonte: Naturatins, 2017

Há uma conjuntura municipal, inclusive determinada no Plano Diretor de 2006, de desenvolvimento do setor agropecuário. O fenômeno é recente e talvez os dados de cobertura do solo na bacia ainda não consigam mostrar, mas a tendência é de ampliação das áreas de lavoura.

Segundo dados da Naturatins (2017), na área da bacia do córrego São João encontram-se três propriedades com agricultura tecnificada, cuja principal atividade 
é o plantio da soja. Os produtores B e C já obtiveram o primeiro ano de safra, e o produtor A encontra-se na terceira safra, todas localizadas na margem esquerda do córrego. Na margem direita encontram-se chácaras e fazendas de pequeno porte cuja finalidade principal é a pecuária, conforme ilustrado nas figuras 37 e 38 .

FIGURA 37 - Fazendas com plantações de Soja na margem esquerda da Bacia do Córrego São João

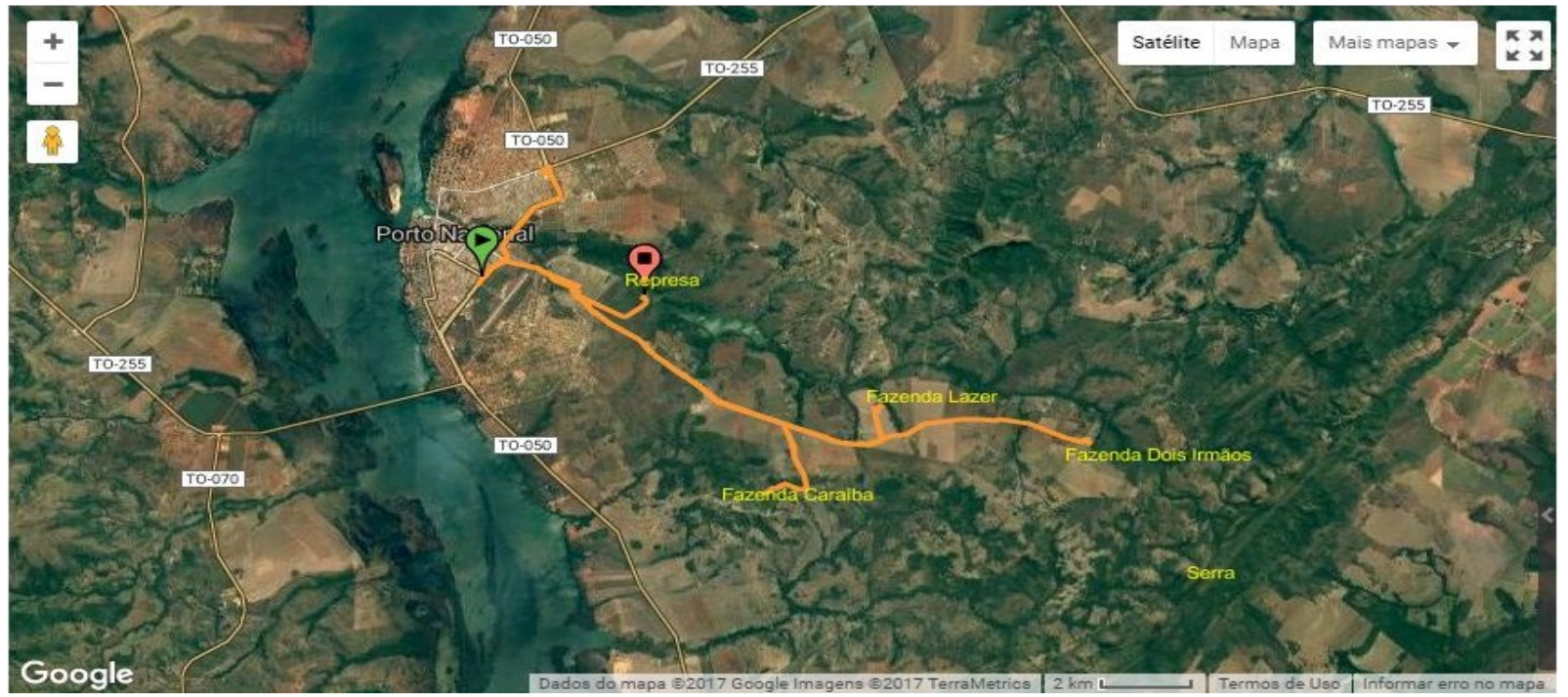

Fonte: Naturatins e ADAPEC, 2017

FIGURA 38 - Fazendas com plantações de Soja na margem direita da Bacia do Córrego São João

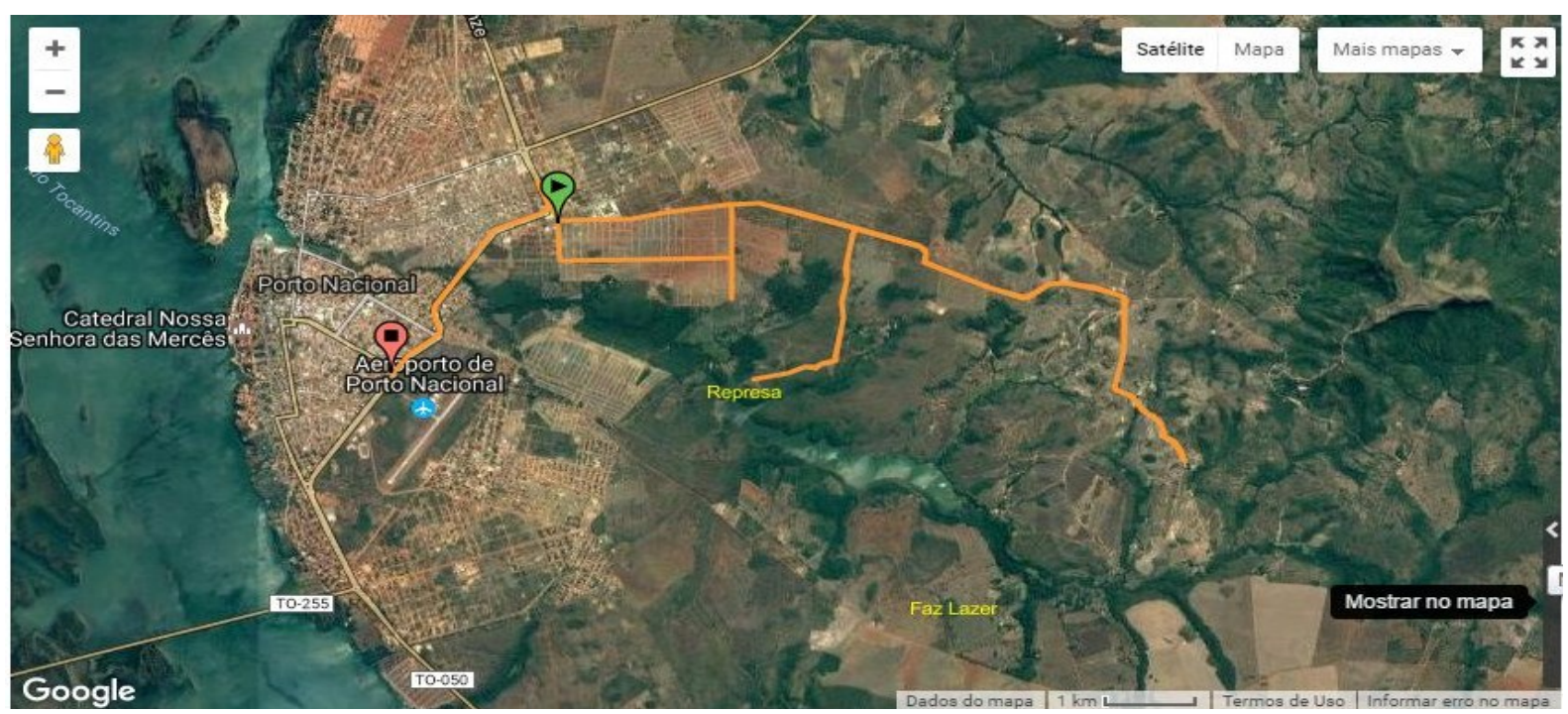

Fonte: Naturatins e Adapec 2017 
Ressalte-se que o consumo de agrotóxicos no Brasil tem crescido acima da média mundial (ANVISA, Dossiê Abrasco - um alerta sobre o impacto dos agrotóxicos na saúde, 2015). Segundo o dossiê, a soja foi o cultivo que mais demandou agrotóxico, tendo consumido $40 \%$ do volume total de herbicidas, inseticidas, fungicidas e acaricidas em 2010.

\subsubsection{Avaliação da qualidade da água do Córrego São João}

Um grupo de pesquisadores da academia (UFT e IFTO) pesquisou sobre a qualidade da água no Córrego São João, utilizando o índice IQA como parâmetro e a resolução CONAMA 257/2005. O monitoramento foi realizado em três pontos da bacia do Córrego São João, apresentados na Tabela 6, com seis amostras ao longo de um ano. Permitiu uma boa visualização espacial e temporal da qualidade da água.

TABELA 6 - Localização dos pontos de coleta de água no córrego São João em Porto Nacional

\begin{tabular}{l|l|l|ll}
\hline Ponto & Latitude (S) & Longitude (W) & Local de referência & \\
\hline I & $10^{\circ} 44^{\prime} 16,34^{\prime \prime}$ & $48^{\circ} 17^{\prime} 38,17^{\prime \prime}$ & $\begin{array}{l}\text { Próximo à nascente (Fazenda } \\
\text { Pilão) }\end{array}$ & \\
\hline II & $10^{\circ} 43^{\prime} 04,52^{\prime \prime}$ & $48^{\circ} 22^{\prime} 19,77^{\prime \prime}$ & $\begin{array}{l}\text { Represa da Cia de } \\
\text { Saneamento }\end{array}$ & \\
\hline III & $10^{\circ} 42^{\prime} 09,02^{\prime \prime}$ & $48^{\circ} 23^{\prime} 46,46^{\prime \prime}$ & Próximo à foz &
\end{tabular}

Fonte: Carvalho et al. (2016).

Detectaram-se oscilações nos valores do IQA entre os pontos de amostragem, consequentes da dinâmica do uso do solo e da água em cada local. Os pontos um e dois (PI e PII) situados na zona rural da bacia apresentaram valores mais elevados, consequentemente correspondem aos melhores índices, e o ponto três (PIII) localizado na zona urbana apresentou um baixo valor em todo o período estudado, essas variações podem ser contribuições provenientes de indústria, atividades domésticas, drenagem da bacia que afetam a qualidade dos corpos d'água (Carvalho et al. 2016).

A classificação foi realizada de acordo com faixas de IQA utilizadas nos estados de AL, MG, MT, PR, RJ, RN e RS, por apresentarem faixas mais restritivas do que as utilizadas em São Paulo (figura 39). 
FIGURA 39 - Classificação da qualidade da água

\begin{tabular}{|c|c|}
\hline QUALIDADE DA ÁGUA & FAIX DE IOA \\
\hline Ótima & $91-100$ \\
\hline Boa & $71-90$ \\
\hline Razoável & $51-70$ \\
\hline Ruim & $26-50$ \\
\hline Péssima & $0-25$ \\
\hline
\end{tabular}

Fonte: ANA (2015)

Os parâmetros de qualidade de água estudados nesse trabalho foram: temperatura, oxigênio dissolvido (percentual de saturação), pH, nitrogênio total, fosfato total, coliformes termotolerantes, resíduo seco, turbidez e demanda bioquímica de oxigênio. Os resultados dos parâmetros físicos, químicos e bacteriológicos das aguas superficiais do córrego São João foram utilizados no calculo do IQA para o período de setembro de 2014 a fevereiro de 2015 (Carvalho et al. 2016).

O comportamento do IQA apresentou uma variação de 49,74 a 80,72 , durante o período estudado (gráfico 3 ), o estudo revelou que de acordo com os valores obtidos do IQA, a qualidade da água pode ser classificada como boa na maior parte do período.

GRÁFICO 3 - Variação do índice da qualidade da água

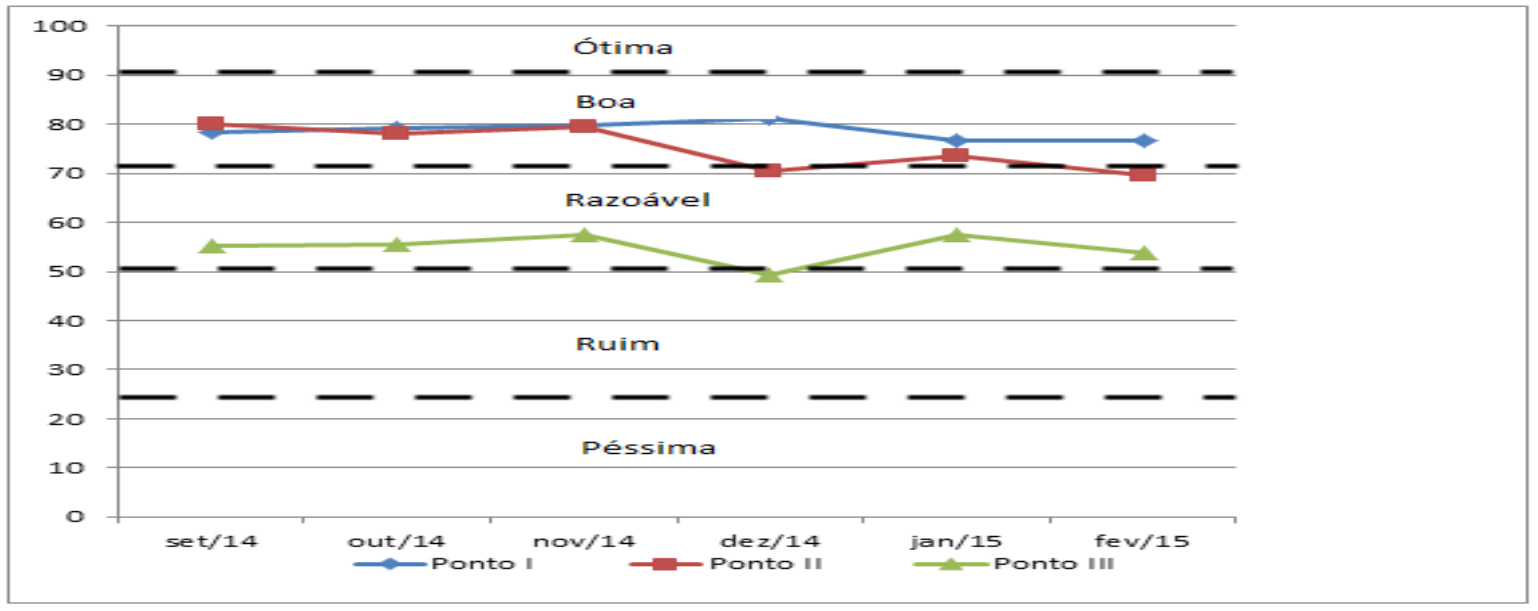

Fonte: Carvalho et al. (2016)

De modo geral que $55,4 \%$ dos valores mensais do IQA podem ser classificados na categoria boa, 39\% na categoria razoável e 5,6\% na categoria ruim. Os baixos valores do IQA relacionaram-se à descarga doméstica, atividades agrícolas e drenagem da bacia hidrográfica (Carvalho et al. 2016). 
De acordo com Carvalho et. al. (2016), a análise dos resultados dos parâmetros considerados no cálculo do IQA, com os limites estabelecidos pelas Resoluções do CONAMA n²74/2000 e n³57/2005, revelou que as águas apresentaram contaminantes que excedem os limites prescritos do enquadramento do Córrego São João (Classe 2). No entanto, é importante ressaltar que é justamente a área a montante de captação que tem os melhores resultados da medição da qualidade da água (pontos I e II).

O Plano da Bacia Hidrográfica do Entorno do Lago (2015) faz também uma avaliação da qualidade do Córrego São João (lá denominado "Ribeirão São João), a partir do monitoramento da qualidade da água bruta no ponto de captação da Cia. de Água, referente aos anos de 2013 e 2014 (Tocantins, 2015). Esta avaliação apontou que a água captada pela ETA 02 é um dos pontos de captação estudados que registram desconformidades de alguns parâmetros qualitativos em relação aos limites permitidos à Classe 2.

O tabela 7 aponta as desconformidades observadas em relação aos limites estabelecidos pela Resolução Conama 357, tanto para a Classe 2 como para a Classe 3. Em vermelho, são indicadas as desconformidades e, em verde, são os parâmetros que ultrapassaram os limites da Classe 2, mas atenderam à resolução na Classe 3. O Plano ressalta ainda que muitos parâmetros estão além dos limites estabelecidos pela Resolução Conama 357 para a Classe 3 (em vermelho), não podendo ser classificado nem como Classe 3. É ainda apontado que uma discussão mais aprofundada é difícil, já que as desconformidades observadas são temporárias, não se mantendo no decorrer das análises em outras datas (FAPTO, 2015).

TABELA 7 - Análise de desconformidades dos parâmetros de qualidade de água bruta considerando-se os limites das Classes 2 e 3 da Resolução Conama No $357 / 2005$

\begin{tabular}{|c|c|c|c|c|c|}
\hline Seção & Data & Parâmetro(s) & Valor & $\begin{array}{c}\text { Max. } \\
\text { Classe } 2\end{array}$ & $\begin{array}{c}\text { Max. } \\
\text { Classe } 3\end{array}$ \\
\hline \multirow{6}{*}{$\begin{array}{l}\text { Ponto } 10 \\
\text { Ribeirão São João } \\
\text { (Porto Nacional) }\end{array}$} & \multirow{2}{*}{$\mathrm{jan} / 13$} & Cloro Residual (mg/L) & 0,100 & 0,010 & 0,01 \\
\hline & & Manganês (mg/L) & 0,258 & 0,1 & 0,5 \\
\hline & jul/13 & Cloro Residual (mg/L) & 0,020 & 0,010 & 0,01 \\
\hline & \multirow{2}{*}{$\mathrm{jan} / 14$} & Ferro Dissolvido (mg/L) & 0,413 & 0,3 & 5 \\
\hline & & Resíduos Sólidos Objetáveis & \multicolumn{2}{|c|}{ Presentes Ausentes } & Ausentes \\
\hline & jul/14 & Ferro Dissolvido (mg/L) & 0,490 & 0,3 & 5 \\
\hline
\end{tabular}

Fonte: Fapto, 2016 
Em suma, embora as informações disponíveis não sejam suficientes para classificar de maneira segura a qualidade de água, há indicativos de que a qualidade da água captada para abastecer a sede de Porto Nacional já não atende aos requisitos mínimos do enquadramento. Importante notar que, nessa análise qualitativa, não foram considerados os contaminantes difusos potenciais, de origem agrícola, na parte alta e média da Bacia.

\subsubsection{Ações de gestão para o controle da poluição das águas}

De acordo com a pesquisa feita na literatura e junto aos diferentes gestores ou interessados pela qualidade de água utilizada para ao abastecimento de Porto Nacional (Naturatins, a Companhia de Abastecimento de Água, Município de Porto Nacional e entidades da sociedade civil), não há um monitoramento sistemático da qualidade das águas ao longo do Córrego São João. Somente a Companhia de Água faz um monitoramento desse corpo d'água no ponto de captação, em atendimento às normas legais de potabilidade (MS No 2.914/2011), mas esses dados não estão disponíveis, embora tenham sido utilizados pelo Plano do Entorno do Lago (FAPTO, 2015).

Também não há nenhuma ação ou programa sistemático de controle das fontes poluidoras. Ressalte-se, contudo, que o Plano Municipal de Água e Esgoto aponta um alto índice de tratamento do esgoto coletado, embora não haja nenhuma informação disponível sobre a eficiência do mesmo.

Somente duas ações relacionadas à qualidade do Córrego São João foram identificadas: a campanha de monitoramento da qualidade de água por Carvalho et al. (2016); e a instauração de um inquérito civil público ( $\left.n^{0} 12 / 2016\right)$ induzido por uma comissão que foi constituída no Fórum Tocantinense de Combate aos Impactos de Agrotóxicos, organizado pelo Governo do Tocantins e pela ADAPEC. Representantes da Naturatins, ADAPEC e a comissão executaram uma ação de investigação no início de 2017 nos empreendimentos rurais situados na área da bacia em estudo (Naturatins e Adapec, 2017).

Em termos de planejamento, o Plano Municipal de Água e Esgoto (2013) prevê um plano de ação por parte da Concessionária para enfrentar os problemas de contaminação de manancial, que deverá ser aprovado pelo Poder Público Municipal. Segundo a Diretoria Municipal de Meio Ambiente, este e os demais planos de ação ainda não foram disponibilizados para a Prefeitura de Porto 
Nacional. O Plano Municipal de Água e Esgoto deverá ser atualizado até outubro de 2017.

Por fim, o Plano da Bacia Hidrográfica do Entorno do Lago prevê a realização de uma campanha de regularização dos usos da água (cadastro e da outorga), com previsão para ser iniciada ainda em 2017. Logo após a conclusão deste processo, o Plano prevê ainda um monitoramento da qualidade das águas, de modo a permitir a definição dos usos preponderantes por bacias e em seguida, o enquadramento dos corpos hídricos, cuja ação está prevista ser executada em médio prazo 4 anos.

\subsubsection{Análise do Risco}

Com base na avaliação do estressor "carga poluidora: pressão sobre a qualidade de água" da demanda por água na Bacia, foi estimado o risco de que a qualidade de água no ponto de captação não seja compatível com o enquadramento de Classe 2 do Córrego São João (Figura 40):

- A ocorrência do estressor é de média intensidade, em função da crescente antropização da área a montante da captação, sobretudo por conta da expansão agrícola e até mesmo de aproximação da mancha urbana, conforme evidenciado no estressor "pressão sobre as condições ambientais".

- Já o impacto foi considerado de média severidade, diante de indícios de violação do enquadramento para alguns parâmetros poluidores (FAPTO, 2015). 
FIGURA 40 - Matriz de risco associado à demanda por água (pressão sobre a quantidade)

\begin{tabular}{|c|c|c|c|c|}
\hline & \multicolumn{3}{|c|}{ Severidade do impacto } \\
\hline & & Baixa & Média & Alta \\
\hline \multirow{3}{*}{ 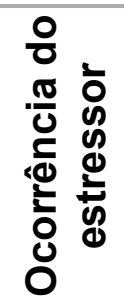 } & Alta & & & \\
\hline & Média & & $\begin{array}{c}\text { Carga } \\
\text { poluidora }\end{array}$ & \\
\hline & Baixa & & & \\
\hline
\end{tabular}

\begin{tabular}{|ll|}
\hline Risco & \\
& Aceitáveis \\
& Toleráveis \\
& Inaceitáveis \\
\hline
\end{tabular}

Portanto, o risco resultante para a qualidade de água do Córrego São João em relação ao estressor "carga poluidora" é considerado tolerável. Ressaltese, contudo, certa fragilidade desta avaliação em função do caráter pontual das duas análises disponíveis sobre a qual ela se baseia (FAPTO, 2015; Carvalho et al., 2016).

Independentemente da avaliação científica da qualidade da água, não há dúvidas de que a qualidade do manancial de captação já é um problema que deve ser prioridade da gestão do Córrego São João. Caso não haja investimentos no controle da poluição e ações preventivas na área a montante da captação para evitar o agravamento da qualidade do Córrego São João, poderá haver problemas de compatibilidade entre a tecnologia de tratamento e a qualidade da água captada pela ETA 02, em termos de riscos à saúde associados ao uso dessa água para consumo humano, conforme exigido pela Portaria MS 2.914/2011.

Nesse sentido, até que se inicia um controle mais efetivo da qualidade das águas do Córrego São João, recomenda-se que seja feita uma análise mais sistêmica da qualidade de água no ponto de captação, com base no histórico do monitoramento que a Companhia de Abastecimento de Água deve realizar, por força de lei. 


\subsubsection{Estressores de água bruta (4): eventos hidrológicos extremos}

Os "eventos hidrológicos extremos" podem afetar a segurança hídrica em suas maiores amplitudes de seca/estiagem severa e de inundações. Como previamente justificado, a avaliação neste trabalho refere-se ao impacto da seca/estiagem severa sobre a quantidade e qualidade de água, enquanto o impacto da inundação se concentra na qualidade da água captada e no risco à integridade física dos subsistemas de captação e tratamento.

No entanto, a Bacia do Córrego São João - assim como a maior parte das unidades hidrológicas da Bacia Hidrográfica do Entorno do Lago - não dispõe de um monitoramento hidrológico, o que impede uma avaliação dos eventos extremos de seca e inundações ao longo dos anos. Dessa forma, a avaliação desse item será qualitativa e puramente indicativa, com base em entrevistas e questionários, em especial da Companhia de Abastecimento de Água de Porto Nacional, além de uma breve apresentação de estudos de precipitação em Porto Nacional, na qual se situa a quase totalidade da Bacia do Córrego São João.

\subsubsection{Precipitação no município de Porto Nacional}

Segundo Pinto; Sousa (2010), o período chuvoso de Porto Nacional corresponde às estações da primavera e do verão (período de setembro a abril), o inverno é a estação mais seca do ano, com quase ausência de chuvas, conforme ilustração no gráfico 4. O período de primavera-verão tem a ocorrência de impactos pluviais vigorosos, devido ao montante das chuvas mensais, o que pode ser observado tanto nas normais climatológicas do período 1931-1960, quanto do período 1961-1990. 
GRÁFICO 4 - Precipitação total (mm) em Porto Nacional -TO (Médias de 19311960 e de 1961-1990)

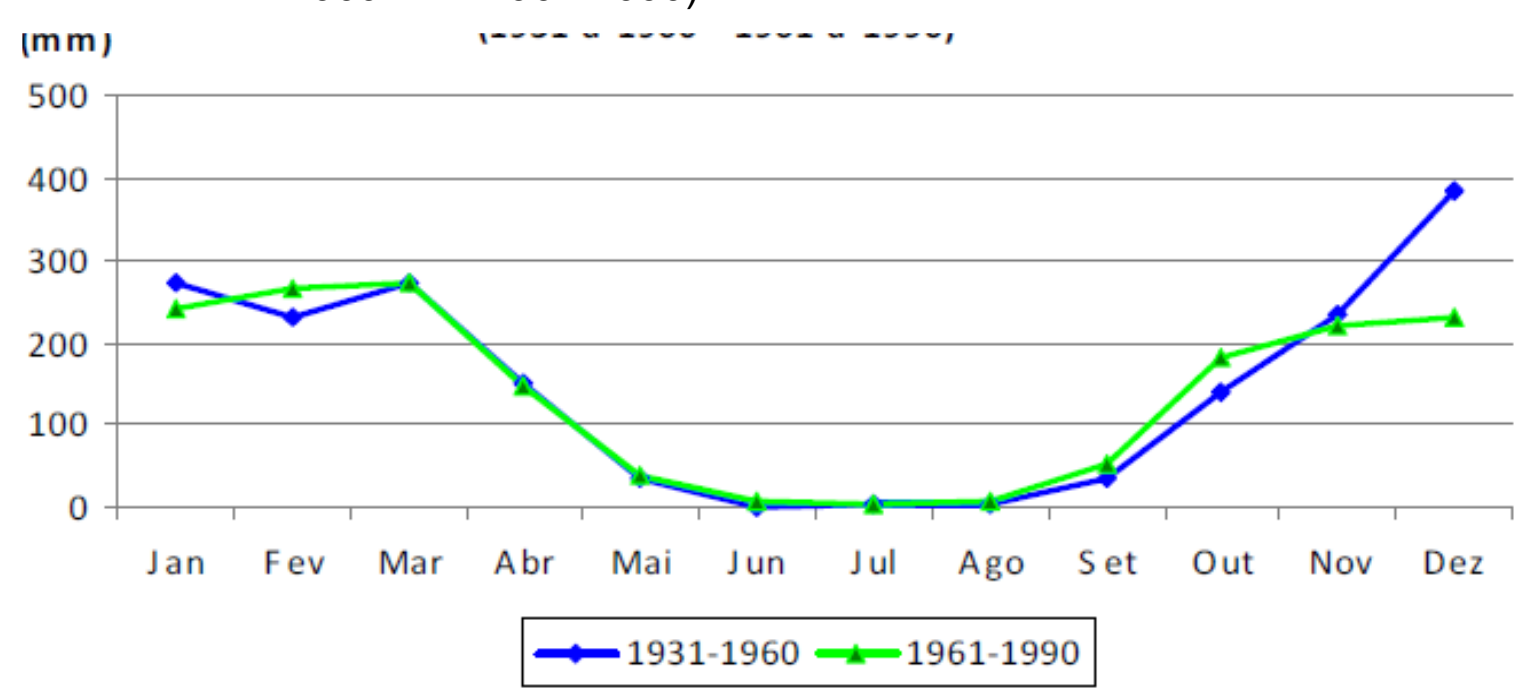

Fonte: Pinto, P.H. e Souza L. B. (2010).

Dados referentes aos elementos que referenciam as condições climáticas do município de Porto Nacional, na figura 41, são disponibilizados pelas Normais Climatológicas disponibilizadas pelo INMET (2015).

FIGURA 41 - Climograma da município de Porto Nacional (2015)

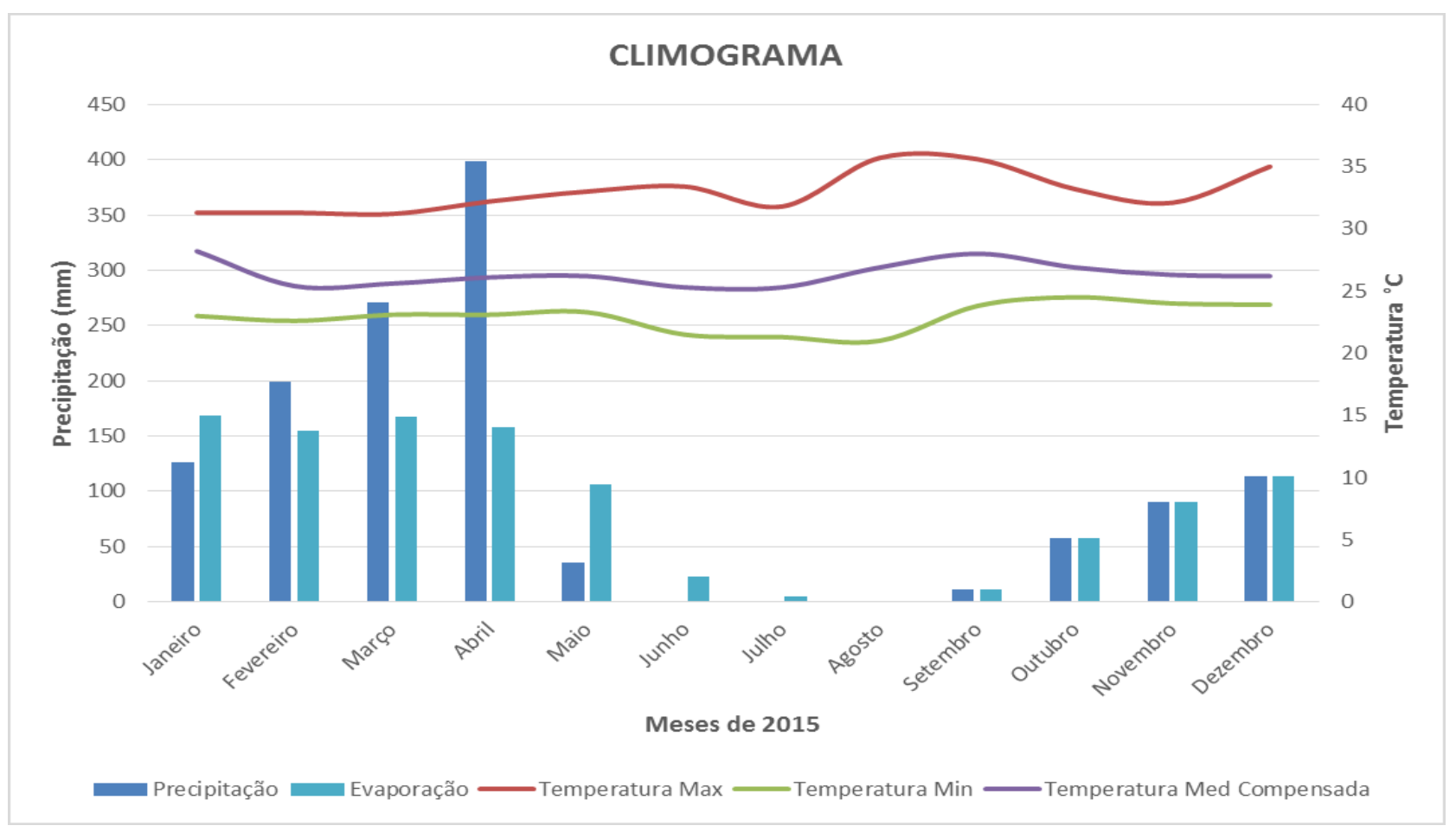

Fonte: INMET, 2015 


\subsubsection{Ocorrência de Seca/estiagem severa}

A estiagem ou escassez severa é um fenômeno natural que ocorre quando há um período de tempo sem a ocorrência de chuvas (ANA, 2015). Quando a estiagem é severa ou prolongada (seca), há uma diminuição da disponibilidade de água, em quantidade e também, às vezes, em qualidade, que pode causar escassez de água e impactar o abastecimento humano e os usos múltiplos.

Segundo relatos de moradores/trabalhadores da área rural, obtidos durante os trabalhos de campo em 2015, 2016 e no primeiro semestre de 2017, os anos de 2015 e 2016 foram particularmente secos, pois nascentes, olhos d'água e "minadores" (afluentes) secaram nesses anos, pela primeira vez em décadas. Pequenos produtores rurais relataram igualmente prejuízos na venda de gado, por falta de pasto e água para dessedentação dos mesmos. Em geral, foi relatado que trechos do próprio Córrego São João diminuíram de maneira significativa.

Por outro lado, relatos de três funcionários aposentados da ETA 02 (entrevistas em abril e maio de 2017) apontaram uma redução progressiva do nível da represa de abastecimento ao longo dos últimos anos (Figuras 42 a 45), sendo que esta redução foi muito mais significativa em 2015 e 2016 que foram considerados anos muito secos. Ressalte-se que a Companhia de Água não respondeu ao questionário, entregue pessoalmente ao engenheiro responsável pela operação da ETA 02.

FIGURA 42 - Represa de Abastecimento

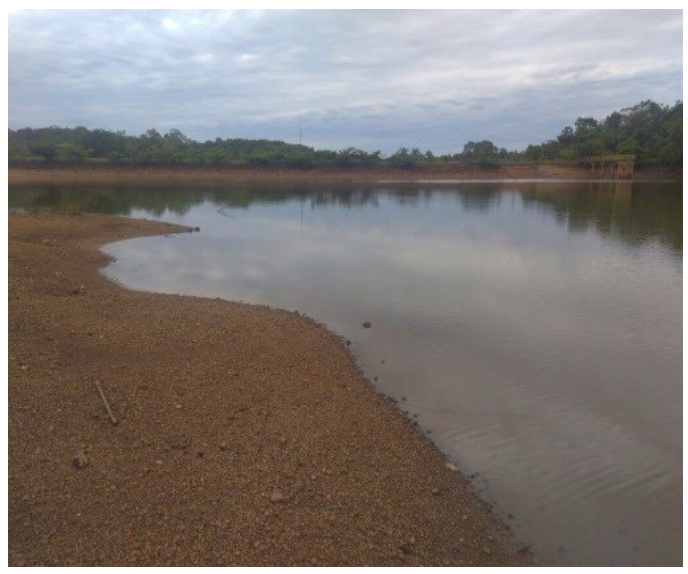

Autora: Bernardeli, M. (07/12/2016)
FIGURA 43- Represa de Abastecimento

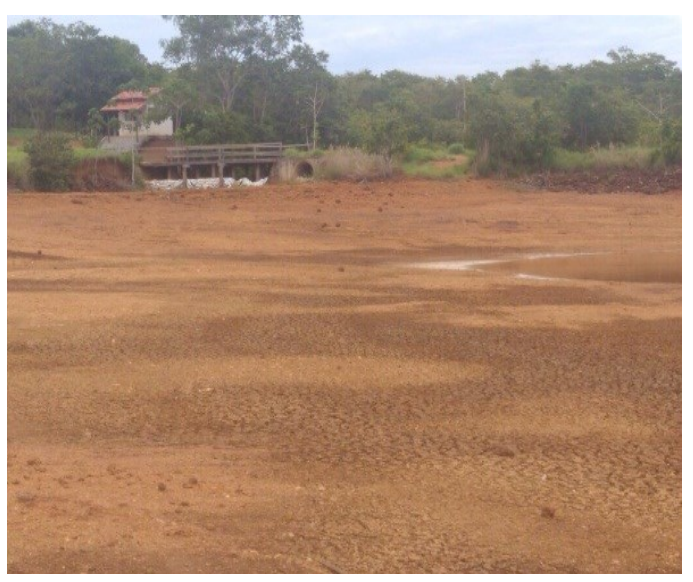

Autora: Bernardeli, M. (07/12/2016) 
FIGURA 44 - Represa de Abastecimento

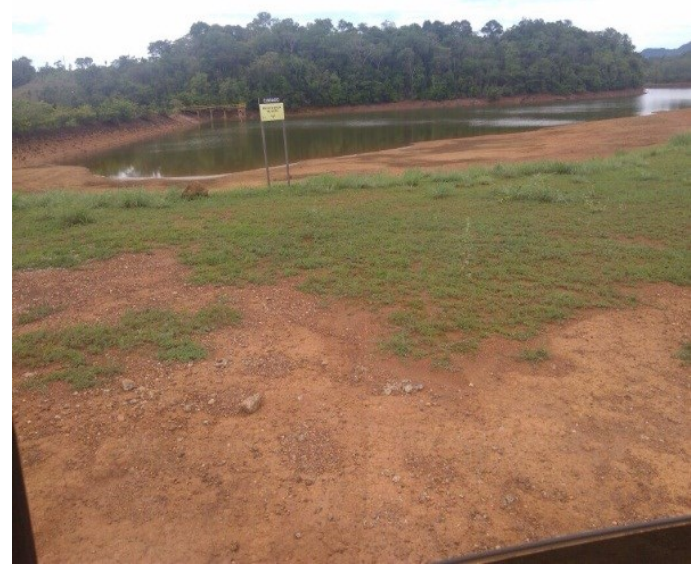

Autora: Bernardeli, M. (07/12/2016)
FIGURA 45 - Represa de Abastecimento

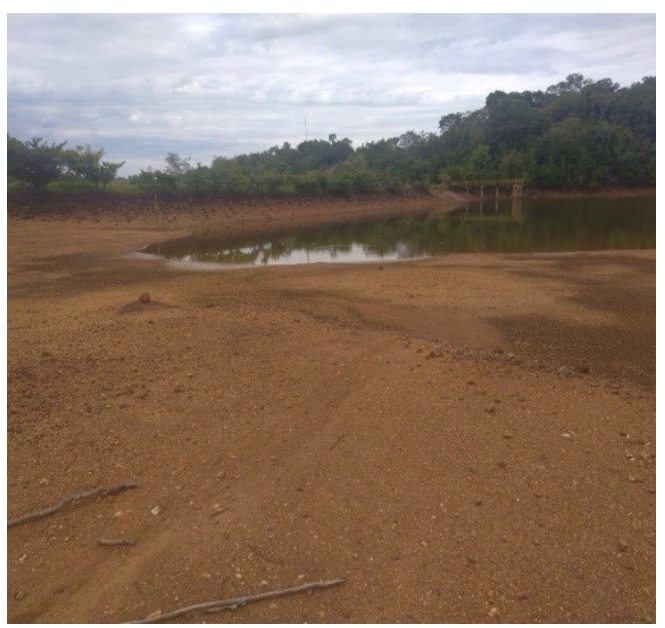

Autora: Bernardeli, M. (07/12/2016)

\subsubsection{Inundação}

Relatos de moradores que moram em áreas próximas ao Córrego São João indicam que os problemas de inundação têm se intensificado e se concentram no trecho urbano da Bacia, portanto a jusante do ponto de captação, no setor Jardim Querido.

Quanto ao Sistema de Abastecimento, os três funcionários aposentados da Companhia de Água relataram que a ETA 02 nunca teve a sua integridade física afetada por inundações nem problemas de qualidade de água durante as cheias que implicassem na interrupção da sua captação.

\subsubsection{Ações de gestão em execução para mitigação dos efeitos de eventos hidrológicos extremos}

Em relação ao risco e impacto de estiagem severa/seca, uma medida importante foi a construção da represa, em 1995, que aumentou sensivelmente a segurança hídrica do abastecimento. Em termos de proteção de mananciais, que aumenta o nível de segurança hídrica a médio e longo prazos, não foram identificadas ações ou programas que busquem proteger este manancial estratégico de Porto Nacional.

Da mesma forma, ações da gestão relacionadas à mitigação dos efeitos de inundação, nos setores que margeiam o córrego São João dentro da cidade, não 
foram identificadas. Esta questão não afeta a segurança hídrica do abastecimento, pois se contra na área a jusante da captação.

\section{$\underline{5.1 .4 .5}$ Análise do risco}

O risco resultante para o estressor "seca/estiagem severa" e "inundações" é puramente indicativo, pois se baseia nos relatos de moradores e trabalhadores rurais da bacia, no trecho a montante da captação da ETA 02.

Com relação à seca, estimou-se que ocorrência do estressor é de média intensidade, de acordo com a percepção dos entrevistados, enquanto o seu impacto foi considerado de média severidade, tomando por base a pressão crescente por demanda de água sobre o Córrego São João, analisada anteriormente, que naturalmente agrava o risco associado à segurança hídrica da ETA 02 durante estiagens severas e secas.

Quanto às cheias, estimou-se que tanto a sua ocorrência quanto seu impacto são baixos para a ETA 02, já que elas ocorrem a jusante do ponto de captação e não há nenhum relato de danos à integridade física dos susbsistemas de captação e tratamento. 
FIGURA 46 - Matriz de risco associado à eventos hidrológicos extremos (pressão sobre a quantidade)

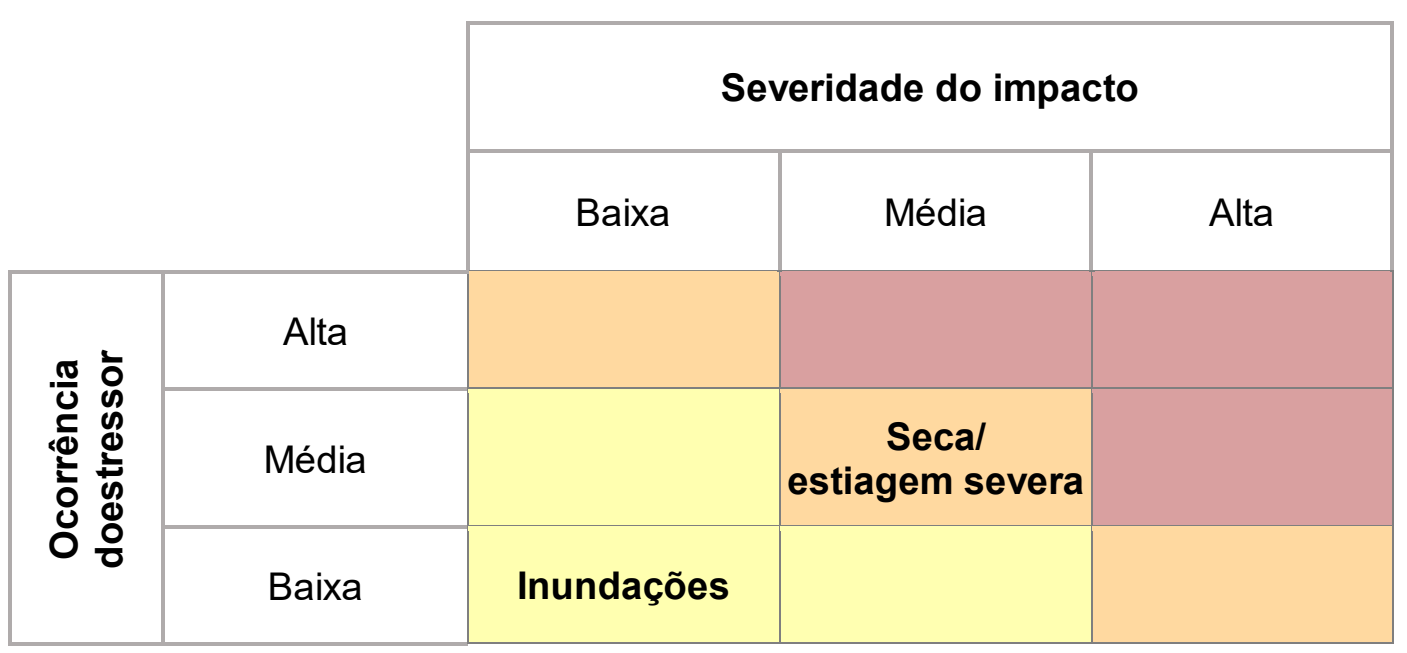

\section{Risco \\ Aceitáveis \\ Toleráveis \\ Inaceitáveis}

Portanto, o risco resultante para a segurança hídrica da ETA 02 é tolerável quando relacionado a estiagens severas e secas e aceitável quanto à inundação.

\subsubsection{Estressor de água bruta (5): acidentes ambientais (fontes fixas e móveis)}

De acordo com a literatura, informações da Naturatins (licenciamento ambiental) e sobretudo incursões de campo, não foi identificada nenhuma fonte fixa capaz de causar um acidente ambiental, na área a montante da captação da ETA 02.

Quanto às fontes móveis, comumente caracterizadas como transportes de produtos químicos perigosos, elas são inexistentes: não há nenhuma rodovia no trecho médio e alto da Bacia nem há registros de acidentes ambientais de fonte móvel, reportado pelo setor de emergências ambientais da SEPLAN na área da bacia a montante da captação do córrego São João. A rodovia TO-050 encontra-se na área a jusante da ETA 02, no trecho urbano de Porto Nacional, correspondente ao anel viário da cidade. 
Portanto, consideramos que a análise para este estressor não é aplicável à bacia de estudo.

No entanto, cumpre ressaltar que é preciso estudar com mais cuidado se há riscos potenciais de acidente ambiental relacionados a estoques de agrotóxicos sem disposição adequada, já que foi confirmado o seu uso na parte montante da Bacia em lavouras de soja (Naturatins, Adapec, 2017).

\subsection{Sistema de Abastecimento Público - ETA 02: avaliação qualitativa da vulnerabilidade}

Conforme o modelo proposto, a avaliação da vulnerabilidade do Sistema de abastecimento de água potável, em relação à exposição dos riscos associados à quantidade e qualidade de água bruta no ponto de captação, será efetuada para os subsistemas de captação e tratamento.

\subsubsection{Subsistema de captação}

Será avaliada, de forma qualitativa, a vulnerabilidade do subsistema de captação face à disponibilidade de água em quantidade, em situações de normalidade hidrológica e de secas, e face à integridade da infraestrutura em situações de inundação (Figura 47).

A vulnerabilidade do Subsistema de captação em situações de normalidade hidrológica foi considerada baixa, resultante da combinação dos seguintes fatores:

- Exposição, estimada como de média intensidade, porque o balanço hídrico já está atingindo (ou já atingiu) o limite outorgável;

- Sensibilidade, avaliada sendo de baixa intensidade, por conta da barragem de acumulação que é uma medida importante de adaptação do sistema de captação.

Em situações de seca, o Subsistema de captação foi avaliado como mais vulnerável (média intensidade), pois:

- Sua exposição passa a ser de alta intensidade, já que a disponibilidade hídrica se torna ainda mais crítica; 
- A sensibilidade da infraestrutura á diminuição do nível do rio continua baixa, por conta da barragem de acumulação que mesmo com seu nível reduzido garantiu a continuidade da captação.

Por fim, a vulnerabilidade do Subsistema de captação em situações de inundação foi considerada baixa, pois a sua exposição é baixa (a área da bacia mais crítica se situa a jusante da captação) e a sensibilidade foi também avaliada como baixa, pois de acordo com relatos de técnicos que trabalharam muitos anos na ETA 02, esta nunca teve sua integridade afetada por este tipo de evento.

Figura 47: Vulnerabilidade do Sistema de Abastecimento/Subsistema de captação de Porto Nacional em diferentes situações hidrológicas

\begin{tabular}{|c|c|c|c|c|}
\hline & & \multicolumn{3}{|c|}{ Exposição } \\
\hline & & Baixa & Média & Alta \\
\hline \multirow{3}{*}{ 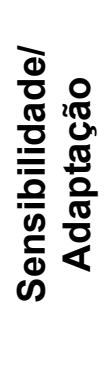 } & Alta & & & \\
\hline & Média & & & \\
\hline & Baixa & $\begin{array}{c}\text { Cheias } \\
\text { (integridade da } \\
\text { infraestrutura) }\end{array}$ & $\begin{array}{l}\text { Normalidade } \\
\text { hidrológica }\end{array}$ & $\begin{array}{c}\text { Estiagem } \\
\text { severa/seca }\end{array}$ \\
\hline
\end{tabular}

\begin{tabular}{|c|}
\hline Vulnerabilidade \\
Baixa \\
Média \\
Alta \\
\hline
\end{tabular}




\subsubsection{Subsistema de tratamento}

A vulnerabilidade do subsistema de tratamento é avaliada face à qualidade de água no ponto de captação em situações de normalidade hidrológica, secas inundações e face à integridade da infraestrutura em situações de inundação (Figura 48).

A vulnerabilidade do Subsistema de tratamento tanto em situações de normalidade hidrológica quanto de seca/estiagem severa foi considerada de média intensidade, resultante da combinação dos seguintes fatores:

- Exposição, estimada como de média intensidade, porque há indícios de comprometimento da qualidade de água em relação ao enquadramento. Por outro lado, não houve relatos de que a qualidade da água tenha piorado durante secas, por isso a exposição foi mantida no mesmo grau;

- Sensibilidade, avaliada sendo de baixa intensidade, por conta da tecnologia de tratamento (sistema convencional) que, segundo a Resolução CONAMA 357/2005, é capaz de tratar água bruta de qualidade Classe II (ou até mesmo III - convencional ou avançado). Além do mais, o sistema de adução entre a captação e a ETA 02 é realizado no ponto de captação que dispõe uma galeria com 12 tampões removíveis, onde aqueles que estão localizados mais próximos do fundo da represa permanecem fechados, ou seja, a água é captada na parte superior da galeria para não ocorrer arrasto de minerais pesados (manganês, zinco e ferro) que ficam decantados no fundo da represa.

Em situações de inundação, o Subsistema de captação foi avaliado como de baixa vulnerabilidade pois a sua exposição é baixa (a área da bacia mais crítica se situa a jusante da captação) e a sensibilidade foi também avaliada como baixa, já os técnicos que trabalharam muitos anos na ETA 02 não relataram nenhum problema de qualidade durante inundações nem problemas de segurança da infraestrutura de tratamento. 
Figura 48 - Vulnerabilidade do Sistema de Abastecimento de Porto Nacional/Subsistema de tratamento em diferentes situações hidrológicas

\begin{tabular}{|c|c|c|c|c|}
\hline & & \multicolumn{3}{|c|}{ Exposição } \\
\hline & & Baixa & Média & Alta \\
\hline \multirow{3}{*}{ 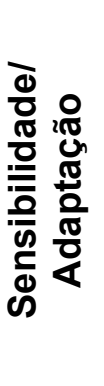 } & Alta & & & \\
\hline & Média & & & \\
\hline & Baixa & $\begin{array}{c}\text { Inundações } \\
\text { (qualidade de água e } \\
\text { integridade da } \\
\text { infraestrutura) }\end{array}$ & $\begin{array}{l}\text { Normalidade } \\
\text { hidrológica e } \\
\text { Estiagem } \\
\text { severa/seca }\end{array}$ & \\
\hline
\end{tabular}

\begin{tabular}{|c|}
\hline Vulnerabilidade \\
Baixa \\
Média \\
Alta \\
\hline
\end{tabular}

A estação de tratamento de água 02 não possui histórico de paralisações recorrentes. Mais recentemente, foi reportada somente uma paralisação no mês de julho no ano de 2009, ocasionada por problemas técnicos na comporta de descarga do fundo da galeria de captação de água bruta (entrevistas com técnicos aposentados da ETA 02).

\subsection{Síntese dos resultados e discussões}

A segurança hídrica do abastecimento de Porto Nacional, nos termos adotados por esta pesquisa, depende da compatibilidade entre a disponibilidade quali-quantitativa da água bruta e as características da ETA 02 (subsistema de captação e subsistema de tratamento). Esta análise indica uma aparente compatibilidade entre o manancial e a ETA, até o presente, de modo que os problemas relacionados à água bruta parecem ter sido capazes de serem resolvidos pela ETA 02 (baixa vulnerabilidade em quase todas as situações hidrológicas, 
exceto em termos de quantidade de água em tempos de seca). Uma questão deve ser ressaltada, contudo: há fontes potenciais de agrotóxico, na parte montante da Bacia, e a ETA 02 não consegue remover este tipo de poluente. Outra medida importante seria a redução de perdas no sistema de distribuição, que poderiam diminuir a vulnerabilidade em relação à disponibilidade hídrica do manancial, que se encontra no limite do outorgável.

Contudo, mesmo que esta análise seja qualitativa e por vezes de valor indicativo, foi possível avaliar que a Bacia Hidrográfica do Córrego São João encontra-se em situação próxima ao limite crítico, enquanto manancial de abastecimento de Porto Nacional. Para facilitar a compreensão do conjunto dos resultados relacionados a este manancial, elaboramos uma matriz síntese com os resultados dos riscos associados a todos os estressores analisados (Figura 49): Pressão sobre as condições ambientais na bacia hidrográfica; Demanda por água (pressão sobre a quantidade); Carga poluidora (pressão sobre a qualidade); Eventos hidrológicos extremos (secas/estiagens severas e inundações).

FIGURA 49 - Matriz dos riscos associados aos estressores analisados

\begin{tabular}{|c|c|c|c|c|}
\hline & & \multicolumn{3}{|c|}{ Severidade do impacto } \\
\hline & & Baixa & Média & Alta \\
\hline \multirow{3}{*}{ 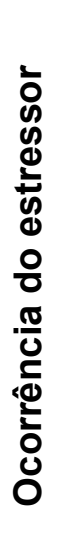 } & Alta & & $\begin{array}{l}\text { Pressão sobre } \\
\text { as condições } \\
\text { ambientais } \\
\text { Demanda } \\
\text { por água }\end{array}$ & \\
\hline & Média & & $\begin{array}{c}\text { Carga } \\
\text { poluidora } \\
\text { Seca/ } \\
\text { estiagem severa }\end{array}$ & \\
\hline & Baixa & Inundações & & \\
\hline
\end{tabular}

\section{Risco}

Aceitáveis

Toleráveis

Inaceitáveis 
Os estressores que apresentam maiores riscos à segurança hídrica do abastecimento de Porto Nacional, em termos de quantidade e qualidade da água bruta, são "pressão sobre as condições ambientais" e a "demanda por água", que levou a um alto nível de comprometimento da disponibilidade hídrica da Bacia Córrego São João. Seu risco são, do ponto de vista da gestão, considerados inaceitáveis, demandando ações urgentes para minimizá-los.

Em um nível de risco imediatamente inferior (tolerável), encontram-se dois estressores (carga poluidora e secas/estiagens severas). Somente inundação foi avaliada como sendo um estressor de nível aceitável para a segurança da disponibilidade de água para a ETA 02, em quantidade e qualidade.

Este conjunto de resultados aponta sobretudo para a necessidade urgente de cuidar da Bacia Hidrográfica do Córrego São João, enquanto manancial prioritário para o abastecimento público de Porto Nacional. Ações de gestão são necessárias e urgentes, em particular:

- Controle do uso da água a montante do ponto de captação da ETA 02, mediante campanhas de regularização do uso da água, e ações de compatibilização dos usos a montante com o abastecimento urbano/humano;

- Programas e medidas de proteção dos mananciais, de modo a proteger as áreas preservadas/conservadas, recuperar APPs de matas ciliares e nascentes, orientar produtores rurais ao correto manejo do uso e ocupação da terra, entre outros. O CAR e o PRAD constituem ferramentas importantes para a identificação das áreas prioritárias de proteção e recuperação.

- Controle da qualidade da água de acordo com a Portaria MS 2.914/2011 e Resolução CONAMA 357/2005. Merece atenção, em especial, o controle de agrotóxicos utilizados pelas lavouras na parte mais alta da Bacia.

Em suma, se não houver ações urgentes de gestão e proteção do Córrego São João, este manancial não será capaz de atender a demanda futura, como projetado pelo Plano Municipal de Água e Esgoto (2013). Talvez ele não consiga nem mesmo atender, no futuro, a vazão atual, caso a pressão sobre a parte montante da Bacia, com a expansão da soja e mesmo da macha urbana continuem, crescendo no mesmo ritmo dos últimos anos.

Para tanto, é necessário mobilizar gestores da água (Naturatins, Comitê de Bacia), o Município - que tem grande responsabilidade na segurança do 
abastecimento de água potável de sua população e na política de uso e ocupação do solo, instituições envolvidas com a vigilância sanitária, a Companhia de Abastecimento de Água, e demais organizações públicas e da sociedade civil interessados no assunto (Ministério Público, ONGs, e outros). 


\section{CONCLUSÃO}

Esta dissertação teve como objetivo geral identificar os principais riscos e vulnerabilidades relativos ao abastecimento público de Porto Nacional/TO, associados à quantidade e qualidade de água bruta da bacia do Córrego São João, e analisar o nível de segurança hídrica atual e futuro do município.

Para tanto, foi utilizado o modelo desenvolvido por Formiga-Johnsson et al., (2017), do qual a mestranda é uma das autoras. O modelo analítico visa avaliar o nível de "segurança hídrica de abastecimentos urbanos" e compreende duas partes distintas e complementares: i) A avaliação do nível de segurança da disponibilidade hídrica de água bruta para o abastecimento urbano, ou o dimensionamento do risco de escassez quali-quantitativa associado a uma série de estressores; e ii) A avaliação da vulnerabilidade do sistema de abastecimento urbano de água, relacionada à quantidade e qualidade dos recursos hídricos captados em determinado ponto da bacia hidrográfica, que envolvem sobretudo o sistema de captação e de tratamento, cujas tecnologias devem ser compatíveis com a disponibilidade da água bruta.

Ou seja, esta pesquisa avaliou, a partir de informações disponíveis na literatura e dados obtidos em pesquisas de campo e entrevistas, o nível atual de segurança hídrica do abastecimento de Porto Nacional e perspectivas futuras.

O principal resultado evidencia que, no momento, ainda há compatibilidade entre a disponibilidade quali-quantitativa da água bruta do Córrego São João e os subsistemas de captação e tratamento da ETA 02. Contudo, mesmo com a deficiência de informações apontadas nesta pesquisa, é possível afirmar que o Córrego São João está no seu limite enquanto manancial de abastecimento de Porto Nacional.

A degradação ambiental enfrentada pela bacia do Córrego São João (desmatamento, ocupação indevida das margens, agropecuária, poluição por esgoto doméstico e até disposição de resíduos sólidos) evidencia que o maior estressor de risco à segurança hídrica do abastecimento de Porto Nacional, relacionada aos problemas de quantidade e qualidade da água bruta, é a demanda por água. Por outro lado, a pressão sobre as condições ambientais da Bacia foi evidenciada pela confecção e análise de mapas de uso e ocupação da terra em 2006, 2011 e 2016; 
constatou-se a evolução (no tempo e no espaço) da ocupação antrópica com implantação de culturas temporárias e de pastagens, além da notória expansão urbana que avança para a porção média da Bacia.

Isso significa que se não houver ações de gestão que controlem o uso da água na Bacia e que busquem proteger e recuperar o manancial nas suas partes alta e média, a montante da captação, o Córrego São João dificilmente permanecerá como manancial suficiente para atender a população urbana da sede. É prioritária a manutenção das reservas legais e das áreas de preservação permanentes (APPs) fluviais e não fluviais, bem como a recuperação das áreas desmatadas que se enquadram nesta categoria, conforme a legislação vigente, e que atualmente estão sendo incorporadas como áreas produtivas da bacia.

A pesquisa evidencia também que a Companhia de Abastecimento poderia participar ativamente dos esforços de proteção deste manancial e deveria empreender ações de controle de perdas - que são extremamente importantes -, pois estas reduziriam a pressão sobre um manancial que já se encontra no seu limite de disponibilidade hídrica. Este problema, no entanto, está na ordem do dia entre algumas instituições diretamente envolvidas ou interessados pela gestão do Córrego São João (Comitê de Bacia Lago de Palmas, MPE-TO, e outros). O envolvimento direto da Naturatins e do Municipio são também fundamentais.

Na verdade, as soluções para os problemas da Bacia dependem, em grande parte, do sistema de governança que envolvem os gestores responsáveis pela quantidade e qualidade de água bem como os demais atores envolvidos ou interessados por suas águas. O estágio de implementação do Sistema de Gestão dos Recursos Hídricos no estado do Tocantins, de instituído pela Lei Estadual $n^{\circ}$ 1.307/2002, encontra-se incipiente, observando-se relevantes lacunas e sobreposição de funções entre órgãos e entidades componentes da administração direta e indireta (Naturatins e Secretaria do Meio Ambiente e Desenvolvimento Sustentável). O comitê da Bacia Hidrográfica do Lago de Palmas, instalado em 2011, poderia assumir um protagonismo na pactuação de ações de proteção e recuperação da Bacia. Por fim, embora as águas da Bacia do Córrego São João sejam estaduais, o município de Porto Nacional tem papel fundamental na proteção da bacia, principalmente pela evidência deste estudo que o maior estressor das suas águas é a pressão do uso e ocupação da terra sobre as condições ambientais da Bacia. Cabe ao município um ordenamento territorial que incorpore no seu 
planejamento a proteção do seu manancial de abastecimento, que se situa quase inteiramente em território portuense.

Quanto ao modelo analítico, este estudo permitiu evidenciar sua utilidade e pertinência na identificação dos principais estressores que pressionam as águas de uma bacia, em quantidade e qualidade, mesmo em situações com poucos dados disponíveis, a exemplo da Bacia do Córrego São João. Para pesquisas futuras, sugere-se que a avaliação da resultante final de risco e vulnerabilidade, na aplicação do modelo analítico, seja feita por um painel de especialistas.

Por fim, sugere-se como estudos prioritários para a Bacia que sejam identificadas as nascentes do Córrego São João e elaborados estudos para implantação de programas direcionados à proteção e recuperação de mananciais, a exemplo dos programas produtores de água e Pagamentos por Serviços Ambientais. 


\section{REFERÊNCIAS BIBLIOGRÁFICAS}

ADGER, W. N. Vulnerability. Global Environmental Change, v. 16, p. 268-281, 2006.

AGÊNCIA NACIONAL DE ÁGUAS (ANA). Evolução da organização e implementação da gestão de bacias no Brasil. Brasília: ANA. 2002.

AGÊNCIA NACIONAL DE ÁGUAS (ANA). Relatório de gestão 2003. Brasília: ANA, 2004

AGÊNCIA NACIONAL DE ÁGUAS (ANA). Diagnóstico e prognóstico do plano de recursos hídricos da bacia do Rio Paraíba do Sul: PGRH-RE-09-R1. Brasília: ANA, 2001. Disponível em: <http://www.hidro.ufrj.br/pgrh/pgrh-re-009-r1/pgrh-re-009r1-cap13.pdf>. Acesso em: 18 ago. 2015.

AGÊNCIA NACIONAL DE ÁGUAS (ANA). Lista de termos para o thesaurus de recursos hídricos da Agência Nacional de águas. Brasília: ANA, 2014.

AUSTRALIA. The national water initiative: securing Australia's water future: 2011 assessment. Canberra: National Water Commission, 354p. 2011.

AUSTRALIAN GOVERNEMENT. Disponível em: http://australia.gov.au/. Acesso em 13 Abril de 2016.

BALDUÍNO, A. R. Qualidade da agua da bacia hidrográfica do ribeirão São João na região centro-norte do Brasil no município de Porto Nacional - Tocantins. 2013 103f. Dissertação (Mestrado em Ciências Ambientais) Universidade de Taubaté, Departamento de Ciências Agrárias. Taubaté, SP, 2013.

BORGES, G. C. Levantamento florístico e fitossociológico em mata de galeria da sub-bacia do ribeirão São João, Porto Nacional, TO. Trabalho de Conclusão de Curso (Graduação em Ciências Biológicas) - Universidade Federal do Tocantins, Porto Nacional. 2007

BRASIL. Lei 9.433, 8 de janeiro de 1997. Institui a Política Nacional de Recursos Hídricos, cria o Sistema Nacional de Gerenciamento de Recursos Hídricos, regulamenta o inciso XIX do art. 21 da Constituição Federal, e altera o art. $1^{\circ}$ da Lei $\mathrm{n}^{\circ}$ 8.001, de 13 de março de 1990, que modificou a Lei $n^{\circ}$ 7.990, de 28 de dezembro de 1989. Diário Oficial [da] República Federativa do Brasil. Brasília, DF, 8 jan. 1997. Disponível em: <http://www.mma.gov.br/port/conamalegiabre.cfm?codl egi=370>. Acesso em: 19 ago. 2015. 
BISPO, M. O. O cerrado tocantinense: o agronegócio, o prodoeste e a do MATOPIBA. In: Fronteira, Território e cidades no Cerrado: Discussões e Reflexões Socioterritoriais. Goiânia, Go: Kelps, 2017.

CARVAlHO, A. P., BALDUINO A. R., MACIEL, G. F., A. P. PICANÇO. Avaliação da Poluição em Rios utilizando índices de qualidade das águas: Um estudo de caso no Ribeirão São João em Porto Nacional - TO. In: São Paulo. UNESP, Geociências, V. 35, N.5, P.394-407, 2016.

CRISTO, S. S. V.; NETO, A. A. S.; Análise do uso e ocupação da terra na bacia hidrográfica do córrego São João através de técnicas de sensoriamento remoto, Porto Nacional, Tocantins, Brasil. In: V Seminário Latino-americano e I Seminário Ibero-americano de Geografia Física, 2008, Santa Maria Rio Grande do Sul. V Seminário Latino-americano e I Seminário Ibero-americano de Geografia Física, 2008. v. 1. P. 1-14.

DEPARTAMENTO DE ECONOMIA RURAL (DERAL) Soja: análise da conjuntura agropecuária. Curitiba: Secretaria de Estado da Agricultura e do Abastecimento, 2013. Disponível em: <http://www.agricultura.pr.gov.br/arquivos/File/deral/Prog nosticos/soja 2013 14.pdf>. Acesso em: 19 ago. 2015.

FAPTO, Fundação de Apoio a Pesquisa do Tocantins. Plano da Bacia Hidrográfica do Entorno do Lago. Relatório Fase A. Diagnóstico da Bacia Hidrográfica, 2015. Acesso em CD-ROOM.

FAPTO, Fundação de Apoio a Pesquisa do Tocantins. Plano da Bacia Hidrográfica do Entorno do Lago. Relatório Fase B. Diagnóstico da Bacia Hidrográfica, 2015. Acesso em CD-ROOM.

FLINKER, R. Planejamento, manejo e gestão de bacias. Disponível em: http://www.planejamento.mppr.mp.br/arquivos/File/bacias_hidrograficas/planejament o_manejo_e_gestao_unidade_1.pdf

FORMIGA-JOHNSSON, R.M. Alocação de água \& Participação em Situações de Escassez: um relato da experiência de gestão compartilhada dos reservatórios da Bacia do rio Paraíba do Sul. Trabalho apresentado no II Simpósio de Recursos Hídricos do Sul-Sudeste, Rio de Janeiro, 2008.

FORMIGA-JOHNSSON, R.M.; MELO, M. C.; BERNARDELI, M.A.F.; e SILVA, P. R. $D E$. Modelo conceitual e metodológico para análise qualitativa da segurança hídrica no abastecimento público de áreas urbanas. Relatório final do Grupo de Pesquisa "Água, Gestão e Segurança Hídrica em tempos de Mudanças Ambientais Globais" Rio de Janeiro, 2017. 
GOMIDE, F. Sobre Reservatórios e Segurança hídrica, 2012, Disponível em: http://www.enercons.com.br/restrito/siteabrapch/sobre_reservatorios_e_seguranca_h idrica.pdf Acesso em 12 de abril de 2016.

GLORIA, R. B. Parâmetros morfométricos areais indicadores de risco da bacia hidrográfica do córrego são João, município de Porto Nacional/TO. $29 \mathrm{f}$. Trabalho de Conclusão de Curso (Graduação em Geografia) - Universidade Federal do Tocantins, Porto Nacional. 2011.

GUERRA, A. J.; ARAÚJO, G. H. \& ALMEIDA, J. R. Gestão Ambiental de áreas degradadas. Rio de Janeiro - RJ: Bertrand Brasil. 2010.

INSTITUTO BRASILEIRO DE GEOGRAFIA E ESTATÍSTICA (IBGE). Censo demográfico 2010. Disponível em: <http://www.ibge.gov.br/home/estatistica /populacao/censo2010/default.shtm>. Acesso em: 03 set. 2015.

INSTITUTO BRASILEIRO DE GEOGRAFIA E ESTATÍSTICA (IBGE). Censo demográfico 2010. Disponível em: http://www.cidades.ibge.gov.br/v3/ cidades/municipio/1718204>. Acesso em: 07 mar. 2017.

LEITE, E. F. Caracterização, Zoneamento Ambiental da Bacia do Rio Formiga Tocantins. Tese de Doutorado em Geografia. Programa de Doutorado em Geografia, Universidade Federal de Uberlândia, Minas Gerais, 2012.

LEITE, E. F.; CARVALHO, E. M. Mapeamento do uso e cobertura da terra na bacia hidrográfica do ribeirão São João, Porto Nacional, Tocantins. Geoambiente OnLine, Jataí, n.20, jan./jun. 2013. Disponível em: < http://revistas.jatai.ufg.br/index.php/geoambiente/article/view/26086/15034>. Acesso em: 03 set. 2015.

LEITE, E. F.; ROSA, R. Uso e ocupação da terra na bacia hidrográfica do ribeirão São João, Porto Nacional, Tocantins. In: SIMPOSIO BRASILEIRO DE SENSORIAMENTO REMOTO,15., 2011, Curitiba, Anais... Curitiba: INPE, 2011. p. 6365-6371.

MELO, M. C. Segurança Hídrica em Áreas Urbanas: estudo de caso da Bacia Rio das Velhas. Tese de Doutorado. Doutorado em Engenharia Civil - Universidade Federal do Rio de Janeiro, Rio de Janeiro. 2016

MINISTÉRIO DO MEIO AMBIENTE. Plano nacional de recursos hídricos: panorama e estado dos recursos hídricos do Brasil: volume 1. Brasília, DF: MMA, 2006.

NOGUEIRA, M. A. R. B. Variabilidade Climática, Disponibilidade Hídrica e ETA Ghandu: Uma analise Qualitativa de Vulnerabilidade. Dissertação Mestrado em 
Engenharia Ambiental - Universidade Estadual do Rio de Janeiro, Rio de Janeiro. 2011

OCDE. Studies on Water. Water Security for better lives. 2013 Disponível em: $<$ dx.doi.org>. Acesso em 30 de maio de 2016.

OLIVEIRA, I. G. Estudo Limnológico do Córrego São João: Características Físicas e Químicas. 111 f. Trabalho de Conclusão de Curso (Graduação em Ciências Biológicas) - Universidade Federal do Tocantins, Porto Nacional. 1999.

PEREIRA, D.S.P.; FORMIGA-JOHNSSON, R. M. Governabilidade dos recursos hídricos no Brasil: a implementação dos instrumentos de gestão na bacia do rio Paraíba do Sul. Brasília, DF: Agência Nacional de Águas, 2003. 82 p.

PEREIRA, D.S.P.; FORMIGA-JOHNSSON, R.M. Descentralização da gestão dos recursos hídricos em bacias nacionais no Brasil. Revista de Gestão de Água da América Latina, v. 2, n. 3, jan./jun. 2005, p. 53-72.

PORTO NACIONAL, Lei Complementar 05, de 28 de setembro de 2006 . Dispõe sobre o plano diretor de desenvolvimento sustentável de Porto Nacional e dá outras providências. Prefeitura Municipal de Porto Nacional. Porto Nacional, 28 set. 2006. Disponível em: < http://www.portonacional.to.gov.br/administracao/files/files Lei\%20Plano\%20Diretor\%20Lei\%20Complementar\%20n\%C2\%BA\%2005-06.pdf>.

Acesso em: 20 ago. 2015.

PORTO NACIONAL, Plano Municipal de Água e Esgoto PORTO NACIONAL, 2013. Dispõe sobre o plano municipal de água e esgoto de Porto Nacional e dá outras providências Prefeitura Municipal de Porto Nacional. Porto Nacional, outubro 2013.

RAMOS, A. M.; SANTOS, L. A. R.; FORTES, L.T.G. (org.) Normas Climatológicas do Brasil 1961-1990. Brasília: INMET, 2009.

REBOUÇAS, A. C. Águas subterrâneas. In: REBOUÇAS, A. C; BRAGA, B. e TUNDISI, J. G. Águas doces no Brasil: capital ecológico, uso e conservação. São Paulo: Escrituras. 1999.

RIBEIRO, L. S. A fotografia como recurso metodológico em ações de Educação Ambiental, a partir do Ribeirão São João, Porto Nacional/TO. Trabalho de Conclusão de Curso (Graduação em Ciências Biológicas) - Universidade Federal do Tocantins, Porto Nacional. 2014

ROCHA, C. E. R.O processo de territorialização da agricultura moderna e a expansão da produção de soja no município de Porto Nacional- TO - Tocantins. 
2015 122f. Dissertação (Mestrado em Geografia) - Universidade Federal do Tocantins- UFT. Porto Nacional, TO, 2015

ROSA, R. Introdução ao Sensoriamento Remoto 4 ed. - Uberlândia: Editora da Universidade Federal de Uberlândia, 2007.

ROSS, J. L. S. Geografia do Brasil 6 ed. . 1. Reimpr. - São Paulo: Editora da Universidade de São Paulo, 2011.

SECRETARIA DE PLANEJAMENTO DO ESTADO DO TOCANTINS. Atlas do Tocantins: subsídios ao planejamento da gestão territorial. Palmas: SEPLAN, 2008.

SILVA, A. A. F. Geoprocessamento aplicado à análise e mapeamento geomorfológico da bacia hidrográfica do ribeirão São João-TO. 2010, 35 f. Trabalho de Conclusão de Curso (Graduação em Geografia) - Universidade Federal do Tocantins, Porto Nacional. 2010.

SOUZA, L. B. A Hipérbole Mercantil da Expansão Urbana e suas Implicações Ambientais. Revista Mercartor, v. 14, n. 4, dez. 2015, p. 159-180.

TAN, P. L.; BOWMER, K. H.; BALDWIN, C. Continued challenges in the policy and legal framework for collaborative water planning. Journal Hydrology,2012, doi:10.1016/j.jhydrol.2012.02.021

TOCANTINS. Lei $n^{\circ} 1.307$, de 22 de março de 2002. Institui a Política Estadual de Recursos Hídricos e adota outras providências. Diário Oficial do Estado do Tocantins. Palmas, 22 mar. 2002. Disponível em: < http://mpto.mp.br/intranet/ caopma/leg est/LEI\%201.307,\%20DE\%2022\%20DE\%20MAR\%C3\%870\%20DE \%2 02002.pdf>. Acesso em: 19 ago. 2015.

TUNDISI, J. G. Água no século XXI: Enfrentando a escassez. São Carlos, SP: Rima, 2009.

VERGARA, F. E. Suporte Metodológico para a Gestão Estratégica de Conflitos Relacionados ao Uso dos Recursos Hídricos. 2007. 273f. Tese de Doutorado em Tecnologia Ambiental e Recursos Hídricos, Departamento de Engenharia Civil e Ambiental, Universidade de Brasília, Brasília, DF, 2007.

UN WATER. Water Security \& the Global Water Agenda A UN-Water Analytical Brief., 2013, Disponível em: http://www.unwater.org/downloads/watersecurity ana lyticalbrief.pdf . Acesso em: 12 de Abril de 2016. 